UNIVERSIDADE DE SÃO PAULO

INSTITUTO DE GEOCIÊNCIAS

\title{
AVALIAÇÃO DO COMPORTAMENTO DE ONDAS ULTRASSÔNICAS NO MONUMENTO ÀS BANDEIRAS
}

Alexander Martin Silveira Gimenez

Orientadora: Profa. Dra. Eliane Aparecida Del Lama

Dissertação de Mestrado

Programa de Pós-Graduação em Mineralogia e Petrologia

São Paulo 
Ficha catalográfica preparada pelo Serviço de Biblioteca e Documentação do Instituto de Geociências da Universidade de São Paulo

Gimenez, Alexander Martin Silveira

Avaliação do comportamento de ondas

ultrassônicas no Monumento às Bandeiras. - São

Paulo, 2012 .

73 p.: il + anexos

Dissertação (Mestrado): IGc/USP

Orient.: Del Lama, Eliane Aparecida

1. Ultrassom 2. Monumentos históricos 3. Patrimônio histórico 4. Geociências 5. Mineralogia aplicada I. Título 
"Aos meus pais, Oscar e Martha pela força e perseverança em meu preparo para a vida." 


\section{Agradecimentos}

Expresso meus sinceros agradecimentos a todos aqueles que de alguma forma prestaram sua contribuição para que este momento fosse alcançado:

A minha esposa, Vanessa Lara, por me apoiar nos momentos de dúvida e me encorajar a sempre prosseguir.

A minha família, Oscar, Martha, Erlinda, Gerônimo, Norma, Stephanie, Christian, Carol, Persio e Cleusa, saibam que cada um de vocês, ao seu jeito, me ajudou a chegar aqui.

A minha orientadora, Professora Doutora Eliane Aparecida Del Lama, pela excelência profissional, confiança, apoio e amizade construída ao longo destes anos de trabalho.

Ao geólogo Lauro Kazumi Dehira, por todo o tempo e trabalho prestado nos campos e também pelas belas imagens cedidas a esta dissertação.

A equipe da Professora Eliane: Mirian, Luciane (Kupiska), Dani, Diego e Eva pelas trocas de conhecimentos.

À Natalia (Spaña) pelo apoio com o ArcMap e a disposição para me auxiliar em diversos momentos.

Ao Professor Dr. Yushiro Kihara, por seu apoio em dois momentos, como funcionário da ABCP e como estudante de geociências.

A amiga Celina Yokoyama, por sempre acreditar em mim e me incentivar a buscar o meu ideal.

A meus amigos e conselheiros de geologia, Vagner Maríngolo (Mabel), Lucas Warren (Falcon), Fernanda Quaglio, Andrés Bustamante, Paula Sucerquia, Daniel (Pegmatito), Carlos Mario, Marlei Chamani (Trilô), Carlos Grohmann (Guano), Elisa (Farol), Andrea (Gemida), Renato (Mimoso), Camilo Bustamante, Rafaela (Biloba), Pedro (Morsa), dentre muitos outros conselheiros que conheci no IGc-Usp.

Aos amigos e amigas, Pâmella, Daiane, David, Magaly, Andressa, Luciana, Karen, Shimabuko, Romualdo, Izilda, Camila, Marco (Bota Fora) e todos aqueles que me acompanharam neste processo. Minhas sinceras desculpas caso tenha me esquecido de mencionar alguém.

Ao DPH da Prefeitura de São Paulo pela autorização de acesso ao Monumento às Bandeiras.

À FAPESP (proc. n. 2009/02519-8) pelos recursos disponibilizados para a aquisição dos equipamentos utilizados nesta pesquisa.

À CCB - Cimpor Cimentos do Brasil Ltda. pela disponibilidade de tempo para os estudos. E aos amigos Donizeti, Eliane, Carlinhos, Marcia, Ilson, Cesar, Manoel, Samuel, Neuromar, Vanelise, Ana Cristina e Vanessa. 


\section{Resumo}

O Monumento às Bandeiras de Victor Brecheret, constituído pelo Granito Mauá, é um símbolo do povo paulistano e o trabalho de uma vida de um dos mais importantes artistas brasileiros.

É no contexto da importância cultural e histórica desse monumento e, principalmente no intuito de contribuir com sua conservação, que este estudo se insere, objetivando a avaliação da rocha que o compõe, por meio de da utilização de método não destrutivo baseado na propagação de ondas ultrassônicas.

O estudo abordou a avaliação de uma amostra sã da mesma rocha do monumento coletada no seu local de ocorrência, efetuando-se a comparação entre os valores das velocidades de propagação obtidas nesta amostra e das obtidas diretamente no monumento. Para tanto, foram adequadas as metodologias para que os dados obtidos no laboratório pudessem ser comparados aos levantados in loco. Dessa forma, foram adaptados todos os procedimentos para ambas as aplicações, eliminando o maior número de variáveis passíveis de interferência nos resultados, inclusive as que envolvem a operação do equipamento.

As medições tanto no monumento como no laboratório abordaram a aplicação de três formas de transmissão: direta, semidireta e indireta. Por sua vez, foram aplicados três pares de transdutores distintos, $54 \mathrm{kHz}, 150 \mathrm{kHz}$ e exponenciais, para cada uma delas.

Apuradas as avaliações em ambas as condições e tratados os dados, pôde-se concluir que o Monumento às Bandeiras ainda permanece em boas condições de conservação, uma vez que as velocidades de propagação de ondas ultrassônicas obtidas no monumento apresentaram-se na ordem de 4.600 a $5.300 \mathrm{~m} / \mathrm{s}$, variando de acordo com o tipo de transmissão aplicada. No laboratório, os resultados obtidos variaram de 4.600 a $5.500 \mathrm{~m} / \mathrm{s}$. 


\begin{abstract}
The Monumento às Bandeiras of Victor Brecheret is constituted of Mauá Granite. It is a symbol of São Paulo people and the masterpiece of one of the most important Brazilian artists.

This study aimed to assess the conservation status of the stone which composes this monument by using the non-destructive method of propagation of ultrasonic waves. This study was carried out considering the importance of this monument and mainly to contribute to its conservation using a geological approach.

In this study the values of the P-wave velocities in the monument were compared with the values obtained in the laboratory sample, which was collected in the original quarry of the same stone of the monument.

Appropriate methodologies were used in this study to obtain the values of velocities in laboratory and in situ. All the procedures were adapted for both applications in order to eliminate as many variables as possible which would affect the results and interpretations, including the operation of the equipment itself.

Three types of transmission were used: direct, semi-direct and indirect, with three different transducer pairs: $54 \mathrm{kHz}, 150 \mathrm{kHz}$ and exponentials.

The result of these evaluations indicates that the stone of which Monumento às Bandeiras is made is still in good conservation condition, based in the P-wave velocities: ca. 4,600-5,300 m/s, obtained directly in the monument, varying according to the type of transmission applied, and 4,600-5,500 m/s in the laboratory tests. These values are in accordance with non-altered granites.
\end{abstract}




\section{ÍNDICE}

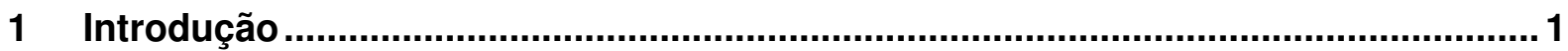

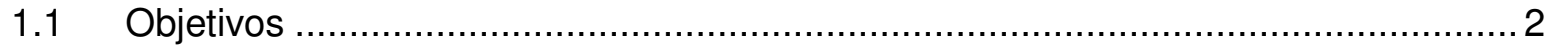

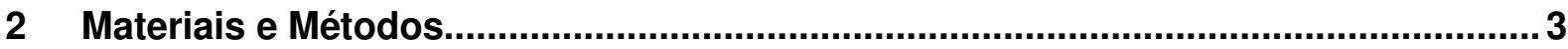

2.1 Autorização de Acesso ao Monumento às Bandeiras .......................................... 3

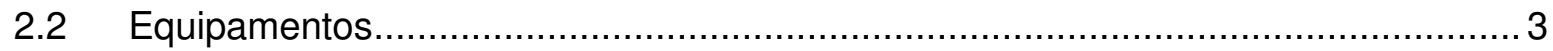

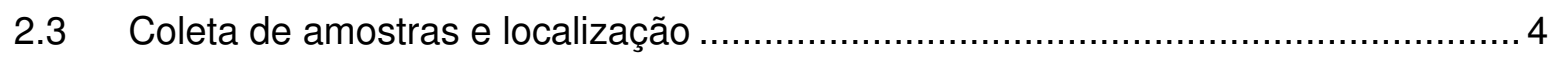

2.4 Unidades de Representação de Resultados ...................................................... 6

2.5 Imagens de Satélite e Mapas …...................................................................... 7

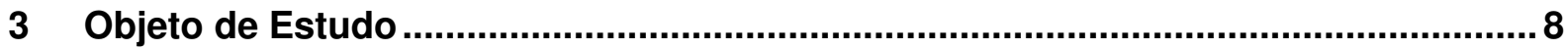

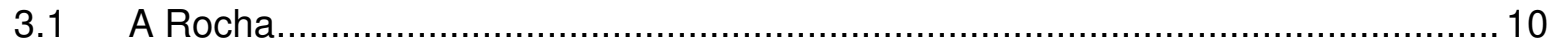

3.2 Implantação do Monumento às Bandeiras ...................................................... 11

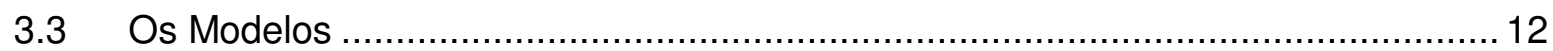

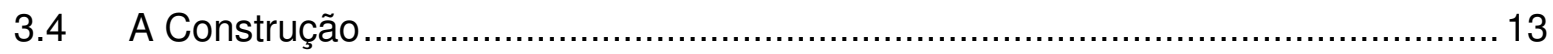

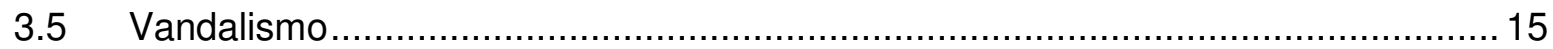

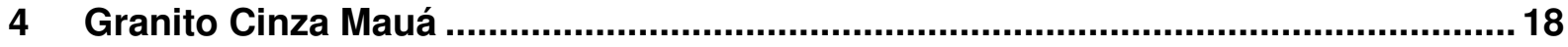

4.1 Características do Granito Cinza Mauá ............................................................. 19

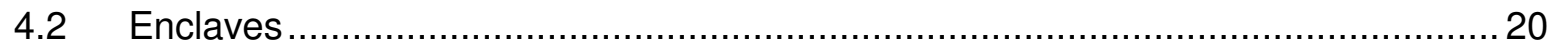

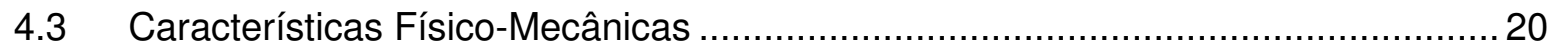

5 Método de Propagação de Ondas Ultrassônicas ................................................. 21

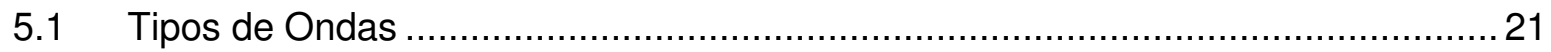

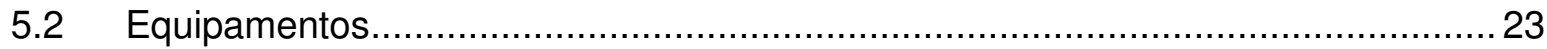

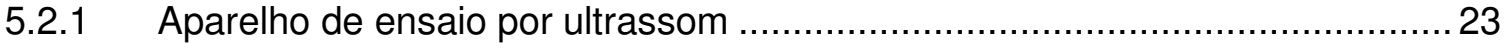

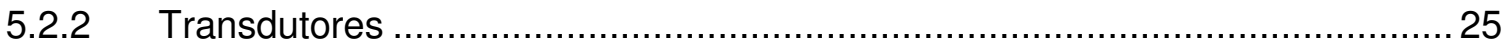

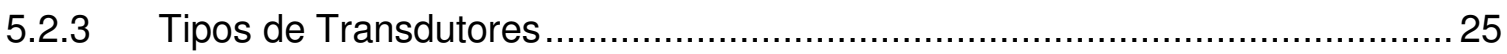

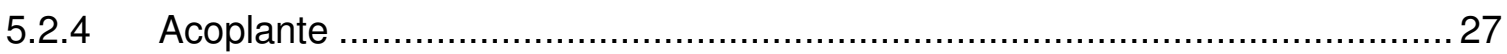

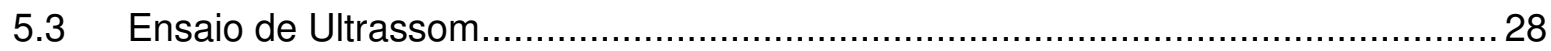

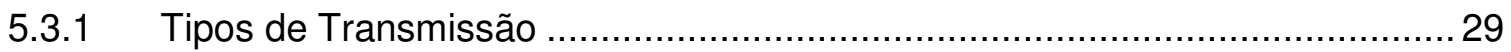


5.3.2 Procedimento de ensaio

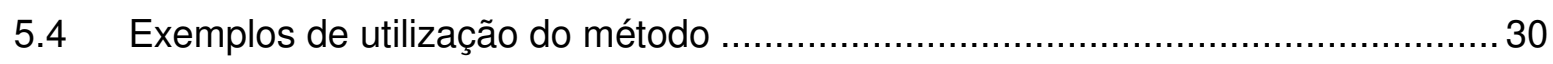

5.4.1 Usos em materiais diversos ................................................................. 30

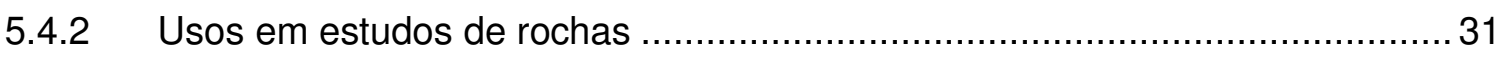

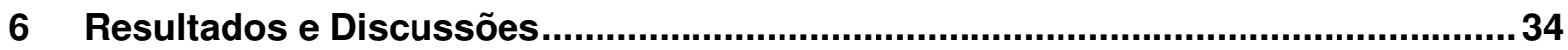

6.1 Preparação da amostra para utilização em laboratório ........................................34

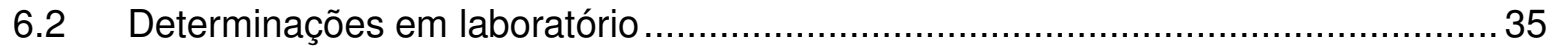

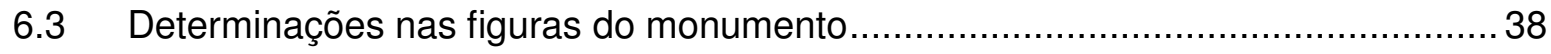

6.3.1 Determinações na base do monumento ................................................ 39

6.4 Condições Gerais de Avaliação Ultrassônica no Monumento às Bandeiras e

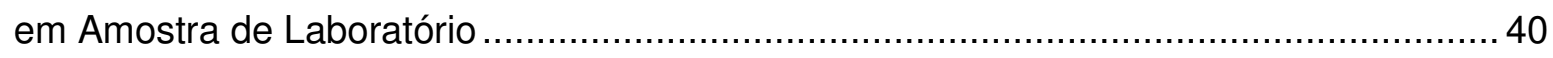

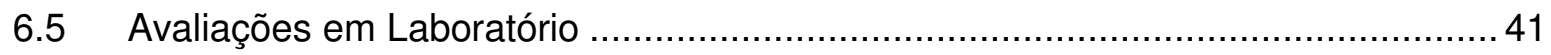

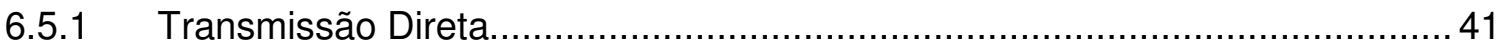

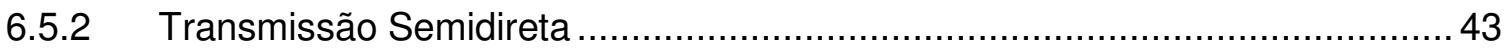

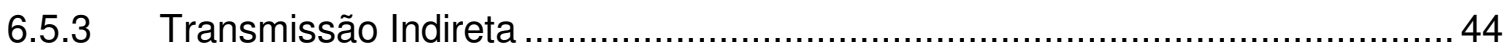

6.6 Comparativos de leituras entre diversos operadores ..................................... 45

6.7 Avaliações no Monumento às Bandeiras .................................................. 54

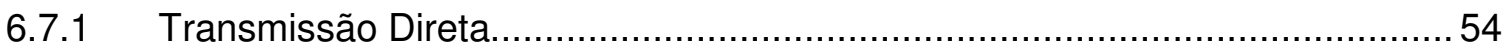

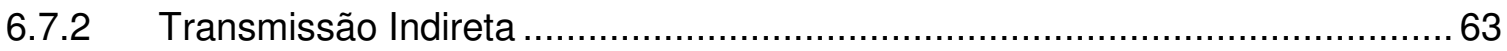

6.8 Correlação entre as análises de laboratório e Monumento às Bandeiras................66

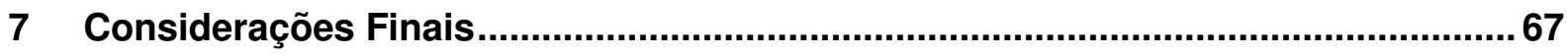

8 Referências Bibliográficas .................................................................................... 70

ANEXOS

Anexo I - Autorização de Acesso ao Monumento às Bandeiras

Anexo II - Tabelas dos valores e resultados obtidos no estudo 


\section{LISTA DE FIGURAS}

Figura 2.1 - Equipamentos para a avaliação de propagação de ondas ultrassônicas. 3

Figura 2.2 - Equipamentos utilizados neste estudo.

Figura 2.3 - Afloramento do Granito Cinza Mauá em Ribeirão Pires - SP, local de extração de cantaria. Foto: Lauro K. Dehira - 30.07.2011. 5

Figura 2.4 - Imagem de satélite da região e dos pontos de coleta de amostra...................... 6

Figura 3.1 - Maquete do Monumento das Bandeiras, 1920. Fonte: Batista (1985)................ 8

Figura 3.2 - Brecheret - Década de 30. Fonte: Batista (1985) ........................................ 8

Figura 3.3 -Brecheret e seus descobridores: Di Cavalcanti, Menotti Del Picchia, Oswald de Andrade e Hélios Seeling. Fonte: Batista (1985) ............................................ 9

Figura 3.4 - Pedreira Irmãos Milanezi, anos 40. Fonte: Batista (1985). 10

Figura 3.5 - Bloco de granito carregado no caminhão, anos 40. Estrada da Pedreira, Mauá, SP.

Figura 3.6 - Estudo de implantação do monumento na praça, 1936. Fonte: Batista (1985).

Figura 3.7 - Implantação do Monumento às Bandeiras na Praça Armando Sales de Oliveira, São Paulo - SP, Imagem de Satélite Atual. Fonte: Google Maps.

Figura 3.8 - Estudos em Barro. Escala 1:10, 1936 (Cavalos - Esquerda; Imagens Direita).

Figura 3.9 - Victor Brecheret retocando modelo em gesso do Monumento às Bandeiras, escala 1:1, 1937. 13

Figura 3.10 - Fundações do Monumento às Bandeiras, 1937. Fonte: Batista (1985). 13

Figura 3.11 - Bloco sendo trabalhado. Oficina Incerpi, fim dos anos 40. Fonte: Batista (1985). 14

Figura 3.12 - O Monumento às Bandeiras montado. Fonte: Batista (1985).

Figura 3.13 - Inauguração do Monumento às Bandeiras, 25 de Janeiro de 1953. Fonte:

Batista (1985).

Figura 3.14 - Pichação com tinta no topo do Monumento às Bandeiras. Fonte: Reys (2006).

Figura 3.15 - Notícia de Jornal de 1ำ de Novembro de 2006 apresentando o barco do Monumento às Bandeiras pichado. Fonte: Jornal Folha de São Paulo - 01/11/2006. 16

Figura 3.16 - Pichação em placa da base do Monumento às Bandeiras. Foto: Eliane A.

Del Lama - 13/07/2008. 16

Figura 3.17 - Dois personagens do Monumento às Bandeiras tiveram unhas pintadas.

Fonte: g1.globo.com - 15/05/2012. 
Figura 4.1 - Representação litoestratigráfica regional da ocorrência do Granito Cinza Mauá (CPRM, 2006).

Figura 4.2 - Granito Cinza Mauá - Bloco extraído para cantaria exposto no município de Ribeirão Pires, SP. Foto: Lauro K. Dehira - 30/07/2011.

Figura 5.1 - (A) Ondas transversais e (B) ondas longitudinais no ar. Fonte: Calegari (2006).

Figura 5.2 - Esquema simplificado de aparelho de ultrassom executando ensaio.

Fonte: Callegari (2006).

Figura 5.3 - V-Meter III - James Intruments Inc.

Figura 5.4 - Transdutores - (A) Transdutores Planos de 150 kHz, (B) Transdutores Exponenciais, (C) Transdutores Planos de $54 \mathrm{kHz}$.

Figura 5.5 - Função do acoplante na interface transdutor/amostra. Imagem adaptada de www.epcapelas.com. 26

Figura 5.6 - Tipos de Transmissão. Fonte: Callegari (2006). 28

Figura 5.7 - Inspeção de concreto armado pelo método de ultrassom. Fonte: Ziegler \& Carmo (2003). 30

Figura 5.8 - Imagens da análise ultrassônica no controle de secagem de madeiras. Transdutores de faces planas [Esquerda] e transdutores de ponto seco [Direita]. Fonte: Calegari (2006).

Figura 5.9 - Execução de ensaio em laboratório em granito. Fonte: Maia (2004). 32

Figura 5.10 - Distribuição de pontos e execução da leitura com ultrassom em monumento [Esquerda] e diagrama das velocidades de propagação de ondas de US no monumento [Direita]. Fonte: Fitzner (2004).

Figura 6.1 - Amostra preparada com faces serradas em quatro lados (vista superior).

Figura 6.2 - Esquema hipotético para medidas de ultrassom em diferentes tipos de blocos de rocha. Fonte: Navarro et al. (2003).

Figura 6.3 - Esquema da disposição dos pontos de leitura em relação aos eixos e faces de referência.

Figura 6.4 - Diagrama da aplicação das leituras da transmissão direta na amostra de laboratório.

Figura 6.5 - Diagrama da aplicação das leituras da transmissão semidireta na amostra de laboratório.

Figura 6.6 - Diagrama da aplicação das leituras da transmissão indireta na amostra de laboratório.

Figura 6.7 - Esquema ilustrativo da aplicação do método ultrassônico pela transmissão direta. Imagem das figuras e pontos de leitura no Monumento às Bandeira apresentando os transdutores, emissor (E) e receptor (R) [Esquerda]. Detalhe dos 
pontos de leitura, posicionamento dos transdutores e percurso da onda [Direita]. Foto:

Lauro K. Dehira - 26.05.2012.

Figura 6.8 - Exemplificação da aplicação da transmissão indireta na base do Monumento às Bandeiras.

Figura 6.9 - Transmissão direta em amostra de laboratório.

Figura 6.10 - Transmissão semidireta em amostra de laboratório.

Figura 6.11 - Transmissão indireta em amostra de laboratório.

Figura 6.12 - Transmissão Direta - Transdutores de 54 kHz - Comparativo com diversos operadores.

Figura 6.13 - Transmissão Direta - Transdutores de $150 \mathrm{kHz}$ - Comparativo com diversos operadores.

Figura 6.14 - Transmissão Direta - Transdutores Exponenciais - Comparativo com diversos operadores.

Figura 6.15 - Transmissão Semidireta - Transdutores de 54 kHz - Comparativo com diversos operadores.

Figura 6.16 - Transmissão Semidireta - Transdutores de $150 \mathrm{kHz}$ - Comparativo com diversos operadores.

Figura 6.17 - Transmissão Semidireta - Transdutores Exponenciais - Comparativo com diversos operadores.

Figura 6.18 - Transmissão Indireta - Transdutores de $54 \mathrm{kHz}$ - Comparativo com diversos operadores.

Figura 6.19 - Transmissão Indireta - Transdutores de 150 kHz - Comparativo com diversos operadores.

Figura 6.20 - Transmissão Indireta - Transdutores Exponenciais - Comparativo com diversos operadores.

Figura 6.21 - Distribuição dos Pontos de Leitura no Lado Direito do Monumento às Bandeiras.

Figura 6.22 - Leituras efetuadas pela transmissão direta no Monumento às Bandeiras na primeira etapa.

Figura 6.23 - Distribuição dos Pontos de Leitura no Lado esquerdo do Monumento às Bandeiras.

Figura 6.24 - Leituras efetuadas pela transmissão direta no Monumento às Bandeiras na segunda etapa de medição.

Figura 6.25 - Resultados de todas as leituras efetuadas pela transmissão direta no Monumento às Bandeiras.

Figura 6.26 - Resultados de todas as leituras efetuadas pela transmissão direta no Monumento às Bandeiras após repetição de leituras para correção de valores. 
Figura 6.27 - Avaliação efetuada pela transmissão indireta em 03/08/2012 pelo aumento gradual de $100 \mathrm{em} 100 \mathrm{~mm}$ entre os transdutores (emissor e receptor).

Figura 6.28 - Avaliação efetuada pela transmissão indireta em 03/08/2012 mantendose distância fixa de $200 \mathrm{~mm}$ entre os transdutores (emissor e receptor) 


\section{LISTA DE TABELAS}

Tabela 6.1 - Resultados médios e desvios na análise da transmissão direta em laboratório.

Tabela 6.2 - Resultados médios e desvios na análise da transmissão semidireta em laboratório.

Tabela 6.3 - Resultados médios e desvios na análise da transmissão indireta em laboratório.

Tabela 6.4-Resultados médios e desvios na análise da transmissão direta no comparativo de diversos operadores.

Tabela 6.5 - Resultados médios e desvios na análise da transmissão semidireta no comparativo de diversos operadores.

Tabela 6.6 - Resultados médios e desvios na análise da transmissão indireta no comparativo de diversos operadores.

Tabela 6.7 - Valores mínimos e máximos dos resultados da velocidade média, desvio padrão e desvio relativo máximo referente ao comparativo entre quatro operadores.

Tabela 6.8 - Nomenclatura dos pontos e local das leituras realizadas no Monumento às Bandeiras na primeira etapa de medição, Face Direita da Vista Frontal.

Tabela 6.9 - Resultados médios e desvios nas análises do Monumento às Bandeiras pela transmissão direta realizadas na primeira etapa de medição.

Tabela 6.10 - Nomenclatura dos pontos e local das leituras realizadas no Monumento às Bandeiras na segunda etapa de medições, Face Esquerda da Vista Frontal.

Tabela 6.11 - Resultados médios e desvios nas análises do Monumento às Bandeiras pela transmissão direta realizadas na segunda etapa de medições.

Tabela 6.12 - Resultados médios e desvios considerando todos os valores coletados do Monumento às Bandeiras pela transmissão direta.

Tabela 6.13 - Leituras repetidas no Monumento às Bandeiras em 03/08/2012 para correção das análises.

Tabela 6.14 - Resultados médios e desvios considerando todos os valores coletados no Monumento às Bandeiras pela transmissão direta após repetir leituras para correção.

Tabela 6.15 - Resultados médios e desvios finais das avaliações efetuadas no Monumento às Bandeiras.

Tabela 6.16 - Resultados médios e desvios referentes à avaliação efetuada pela transmissão indireta em 03/08/2012 pelo aumento gradual de $100 \mathrm{em} 100 \mathrm{~mm}$ entre os transdutores (emissor e receptor). 
Tabela 6.17 - Resultados médios e desvios referentes à avaliação efetuada pela transmissão indireta em 03/08/2012 mantendo-se distância fixa de 200 mm entre os transdutores (emissor e receptor).

Tabela 6.18 - Valores médios da velocidade de propagação de ondas ultrassônicas comparando-se as análises de laboratório com o Monumento às Bandeiras. 


\section{Introdução}

A utilização de rochas como elementos construtivos é uma prática que remonta à evolução humana. Desde a antiguidade as rochas têm uma participação expressiva no contexto da arte e da construção civil.

Diversas são as culturas antigas que possuíam a capacidade de trabalhar a pedra, assim executando belas obras civis, esculturas ou monumentos produzidos em rocha.

Muitas destas obras de arte espalhadas pelo mundo resistiram até hoje à exposição ao ambiente e às intervenções humanas.

No entanto, no ultimo século a deterioração do patrimônio histórico construído foi mais expressiva, ao mesmo tempo em que, por outro lado, é alavancada a consciência quanto às necessidades de sua conservação. Ocorre então um cenário inicial caracterizado na urgência de aplicação de intervenções no intuito de evitar a destruição completa das obras, estas por muitas vezes pouco afortunadas, onde por falta de conhecimento dos processos de alteração dos materiais desencadearam em reações do que se almejavam evitar (Moreno, 2003).

Inúmeras são as obras constituintes do patrimônio histórico imóvel no mundo confeccionadas inteira ou parcialmente em rocha, material este selecionado por sua durabilidade e viabilidade. No entanto, o desconhecimento de suas propriedades pode acarretar problemas posteriores, muitas vezes irreversíveis, e é nesse contexto que a participação de profissionais com conhecimento aplicado de geociências se torna imprescindível para a conservação do patrimônio. São inúmeras as contribuições que a Geologia pode fornecer para a preservação da Herança Cultural (Del Lama, 2006).

A mesma autora aponta que participação de geocientistas em trabalhos voltados para a preservação de monumentos e patrimônio histórico é intensa no mundo, e esta participação tem crescido nos últimos anos no que diz respeito ao Brasil.

Este trabalho trata de um estudo em geociências aplicado à conservação do patrimônio histórico construído, utilizando o método de propagação de ondas ultrassônicas, ou ultrassom, como é popularmente conhecido, na avaliação da integridade física do Monumento às Bandeiras de Victor Brecheret.

O Monumento às Bandeiras por tratar-se de uma obra tombada de grande importância artística e cultural para o povo paulistano e um dos símbolos da cidade de São Paulo, exigiu que seu estudo abordasse uma metodologia não destrutiva, ou seja, uma forma de avaliação que não gerasse nenhuma forma da alteração química ou física ao estado atual do mesmo.

A velocidade de propagação de ondas ultrassônicas é o parâmetro mais comumente utilizado para auxiliar os cientistas na avaliação do estado de degradação de rochas 
presentes em monumentos e esculturas, auxiliando na avaliação dos mecanismos específicos de degradação (Valdeón et al.,1992).

O trabalho abordou dentre seus objetivos o desenvolvimento metodológico da utilização da propagação de ondas ultrassônicas em monumentos constituídos de rocha, e também em estudos de laboratório da rocha que compõe o Monumento às Bandeiras, este construído inteiramente por blocos do Granito Cinza Mauá. Adicionalmente, ao longo do período deste estudo, a metodologia de ensaio contou com a adaptação dos procedimentos sugeridos pelas normas ABNT NBR 8802/94 - Concreto Endurecido - Determinação da velocidade de propagação de onda ultra-sônica e a ASTM D 2845/00 - Laboratory Determination of Pulse Velocities and Ultrasonic Elastic Constants of Rock, de forma a adequar sua utilização para estudos em laboratório e sua reprodução no Monumento às Bandeiras.

\subsection{Objetivos}

Esta pesquisa teve por objetivo avaliar o estado de conservação da rocha que compõe o Monumento às Bandeiras de Victor Brecheret pelo método da propagação de ondas ultrassônicas, buscando-se determinar o valor médio da velocidade de propagação destas ondas in loco, avaliação esta passível de aplicação nessa obra de arte, tombada desde 1985, por se tratar de método não destrutivo.

Além do monumento, foi realizada a avaliação por este método da amostra de laboratório coletada no local de ocorrência da rocha, com o objetivo de utilizar a amostra sã como parâmetro comparativo aos resultados obtidos no monumento.

Finalmente este trabalho abordou também a adequação do método de propagação de ondas ultrassônicas à aplicação específica a monumentos, considerando-se as técnicas, os materiais e características intrínsecas das avaliações ao Monumento às Bandeiras. 


\section{Materiais e Métodos}

\subsection{Autorização de Acesso ao Monumento às Bandeiras}

Foi solicitado ao DPH (Departamento do Patrimônio Histórico) autorização de acesso ao Monumento às Bandeiras, por se tratar de obra de arte tombada de responsabilidade da prefeitura do Município de São Paulo.

O DPH, através do ofício nº 049/DPH-G/2011, expedido em 28 de março de 2011, assinado pelo então diretor, Sr. Walter Pires, posicionou-se favorável ao estudo do comportamento das ondas ultrassônicas no Monumento às Bandeiras.

A cópia do documento de autorização consta no ANEXO I.

\subsection{Equipamentos}

Toda a aparelhagem utilizada neste estudo (Figura 2.1) foi adquirida com o auxílio financeiro da FAPESP (Proc. 2009/02519-8), que foi fundamental na determinação da velocidade de propagação de ondas ultrassônicas, efetuando-se determinações em amostras de laboratório e leituras in loco no Monumento às Bandeiras.

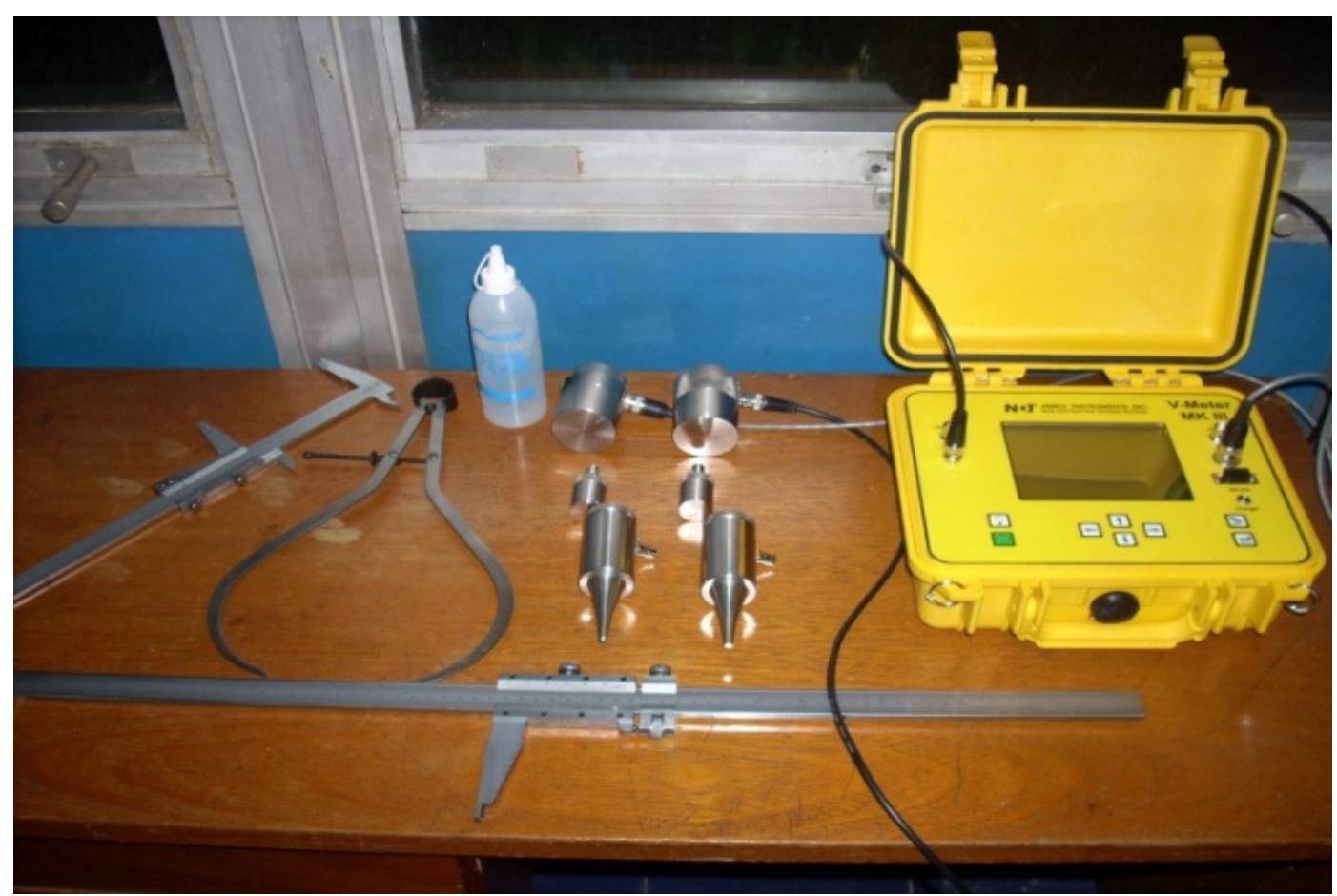

Figura 2.1 - Equipamentos para a avaliação de propagação de ondas ultrassônicas. 
Para a realização das medidas em laboratório e no Monumento às Bandeiras foram utilizados:

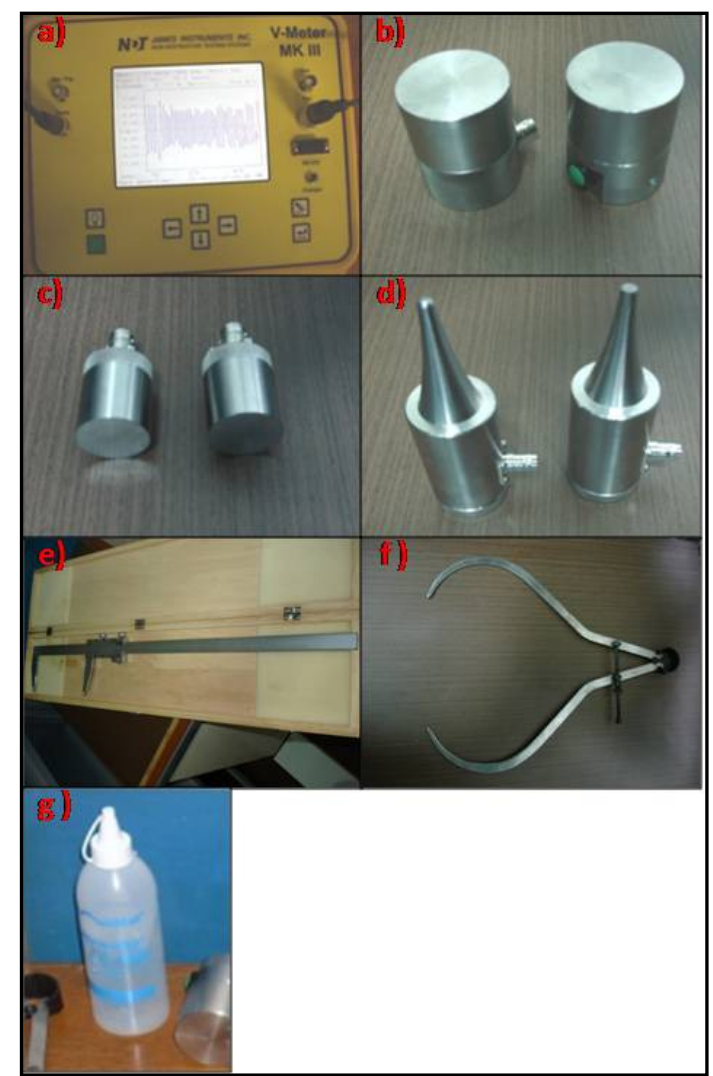

Figura 2.2 - Equipamentos utilizados neste estudo.

a) Aparelho de Ultrassom: Aparelho VMeter III da James Instruments Inc. (Figura 2.2-a).

b) Transdutores Planos de $\mathbf{5 4} \mathbf{~ k H z : ~ P a r ~}$ de terminais acopláveis ao aparelho de ultrassom (emissor/receptor) com diâmetro de $5 \mathrm{~cm}$ (Figura $2.2-\mathrm{b}$ ).

c) Transdutores Planos de 150 kHz: Par de terminais acopláveis ao aparelho de ultrassom (emissor/receptor) com diâmetro de 2,2 cm (Figura $2.2-c$ ).

d) Transdutores Exponenciais: Par de terminais acopláveis ao aparelho de ultrassom (emissor/receptor) de contato pontual (Figura $2.2-d$ ).

e) Paquímetros: Foram utilizados dois paquímetros, um com capacidade de $300 \mathrm{~mm}$ e precisão de $0,05 \mathrm{~mm}$ e outro de capacidade de $600 \mathrm{~mm} \mathrm{e}$ precisão de $0,2 \mathrm{~mm}$, para efetuar as medidas das distâncias entre os transdutores emissor e receptor (Figura $2.2-\mathrm{e}$ ).

f) Compasso Externo: Esta ferramenta é comumente utilizada na indústria mecânica. Neste trabalho a mesma foi utilizada para determinação de distância entre pontos de leitura em peças irregulares (Figura $2.2-f$ ).

g) Acoplante: Gel para ultrassom, utilizado para gerar contato entre os transdutores e amostra (Figura $2.2-\mathrm{g}$ ).

\subsection{Coleta de amostras e localização}

Os estudos realizados em laboratório demandaram amostras de rocha do Granito Cinza Mauá em forma bruta, com pouca influência de ações intempéricas.

Foram colhidas amostras no município de Ribeirão Pires, nas proximidades da Estrada de Sapopemba, em travessa não pavimentada da Av. Miro Atílio Peduzzi 
(Figura 2.3), no acesso à Pedra do Elefante, ponto turístico local. Neste afloramento é visível a extração da rocha artesanalmente para comercialização de rochas de cantaria.

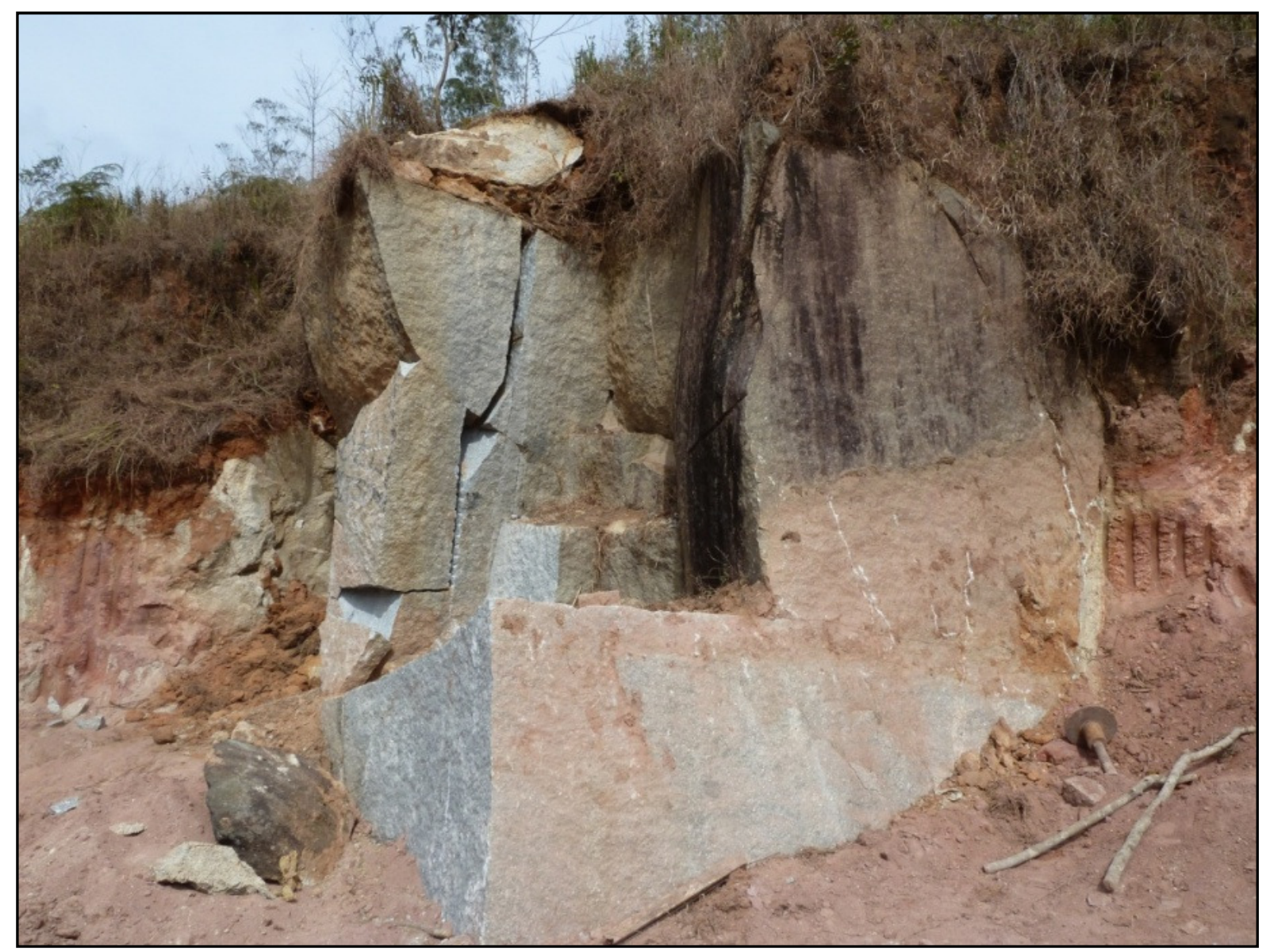

Figura 2.3 - Afloramento do Granito Cinza Mauá em Ribeirão Pires - SP, local de extração de cantaria. Foto: Lauro K. Dehira - 30.07.2011.

Foram coletadas também amostras no bairro vizinho ao afloramento ainda no Município de Ribeirão Pires, seguindo pela estrada de Sapopemba, altura do número 4900, no sentido centro, esquina com a Rua Madrid, neste local pudemos verificar o armazenamento de blocos oriundo do desmonte do Granito Cinza Mauá extraídos para cantaria ainda não trabalhados.

No outro lado da estrada, a poucos metros, há um comércio de pedras de cantaria do Granito Cinza Mauá, denominado como Coopedra, onde se efetuou a compra de amostra em forma de paralelepípedo. A Figura 2.4 mostra os locais de coleta. 


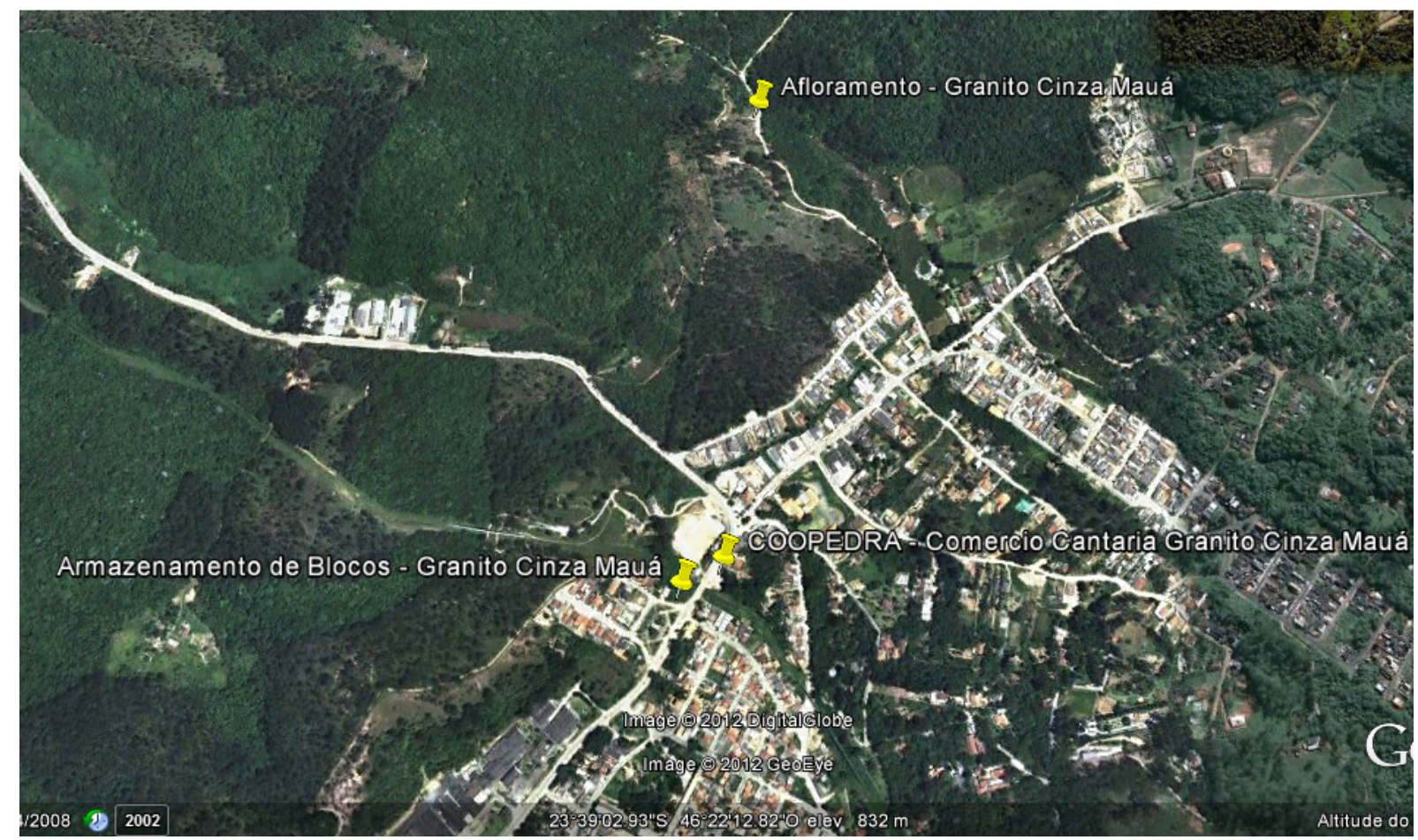

Figura 2.4 - Imagem de satélite da região e dos pontos de coleta de amostra. Fonte: Google Maps.

\subsection{Unidades de Representação de Resultados}

Todas as determinações da velocidade de propagação de ondas ultrassônicas estão apresentadas neste trabalho em metros por segundo $(\mathrm{m} / \mathrm{s})$ de acordo com o Sistema Internacional (S.I.). Utilizou-se o critério de arredondamento ao valor inteiro mais próximo, sem o uso de casas decimais para os resultados das velocidades.

Foi empregado nas análises o desvio padrão das amostragens executadas, bem como o afastamento relativo e o desvio relativo máximo. As unidades destes também estão representadas em $(\mathrm{m} / \mathrm{s})$, considerando-se o valor unitário arredondado ao inteiro mais próximo para o desvio padrão e afastamento relativo, já os valores referentes ao desvio relativo máximo são apresentados em porcentagem, sendo arredondados à primeira casa decimal.

A utilização do afastamento relativo e do desvio relativo máximo baseia-se na norma brasileira ABNT NBR 7215/96, que utiliza destes critérios para a exclusão de resultados discrepantes, o que indica falha na preparação de corpos de prova para o ensaio de resistência à compressão de cimento portland.

Considerou-se viável este critério como ferramenta de auxílio à confiabilidade dos resultados obtidos em laboratório e no Monumento às Bandeiras. 


\subsection{Imagens de Satélite e Mapas}

Neste trabalho, foram utilizadas imagens de satélite obtidas através do programa Google $^{T M}$ Maps, programa livre e gratuito disponível na rede mundial. Este aplicativo foi utilizado para demonstrar as localidades de coletas de amostra, bem como a localização do Monumento às Bandeiras.

O mapa geológico apresentado foi obtido por meio do programa ArcMap® 10 , utilizado para apontar a localização e dimensões do Granito Cinza Mauá que compõe o Monumento às Bandeiras. 


\section{Objeto de Estudo}

Esboçado por Brecheret em 1920 (Figura 3.1), no início do movimento modernista e finalmente inaugurado em 1953, o Monumento às Bandeiras é um dos marcos visuais da cidade de São Paulo (Batista, 1985).

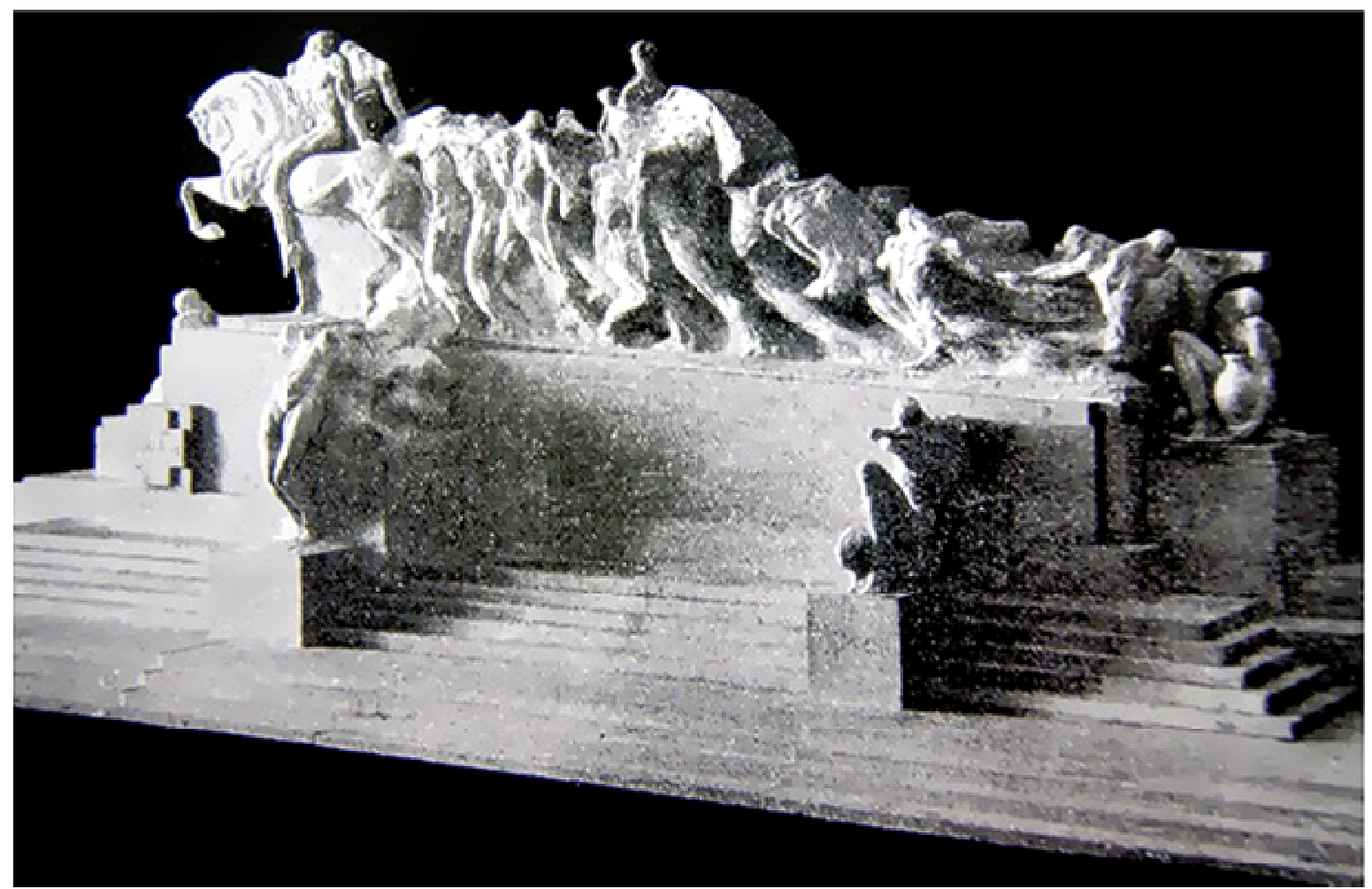

Figura 3.1 - Maquete do Monumento das Bandeiras, 1920. Fonte: Batista (1985).

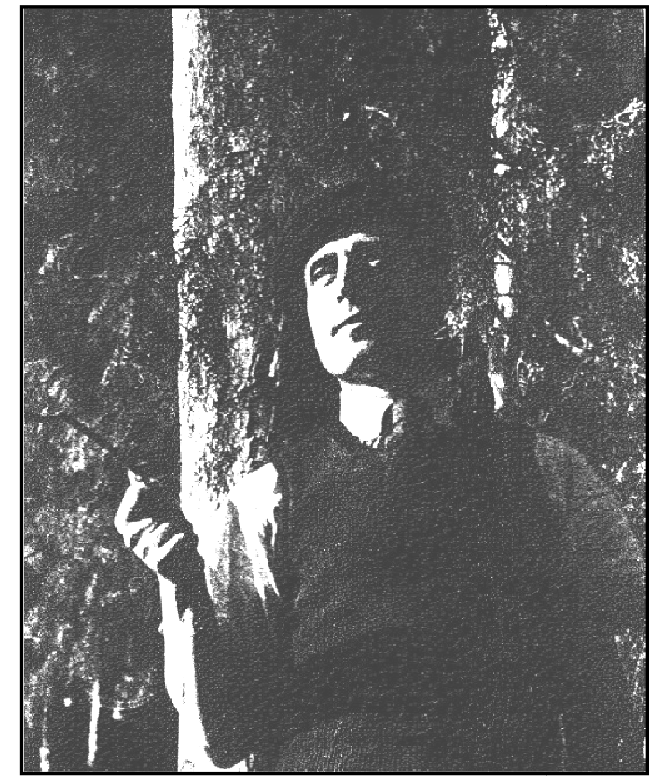

Figura 3.2- Brecheret - Década de 30. Fonte: Batista (1985).
Abordar a história do Monumento às Bandeiras necessariamente requer que seja apresentada parte da história de seu autor, Victor Brecheret (Figura 3.2), artista de origem humilde nascido em Farnese (Itália) em 1894, emigrando para o Brasil em 1906.

Brecheret fixou-se em São Paulo onde estudou desenho, modelagem e entalhe no Liceu de Artes e Ofícios. Posteriormente estudando em Roma, tornou-se discípulo do escultor Arthur Dazzi entre 1913 e 1919 (Batista, 1985)

Em 1920, os modernistas Di Cavalcanti, 
Oswald de Andrade e Hélios Seelinger (Figura 3.3), em uma visita ao palácio das indústrias para conhecer as maquetes do Monumento à Independência, acabam por descobrir o escultor Victor Brecheret que há alguns meses trabalhava em uma sala do Palácio ainda em construção, em espaço cedido por Ramos de Azevedo.

De acordo com o DPH - Departamento do Patrimônio Histórico do Município de São Paulo (2012), suas obras eram consideradas inovadoras para os padrões artísticos

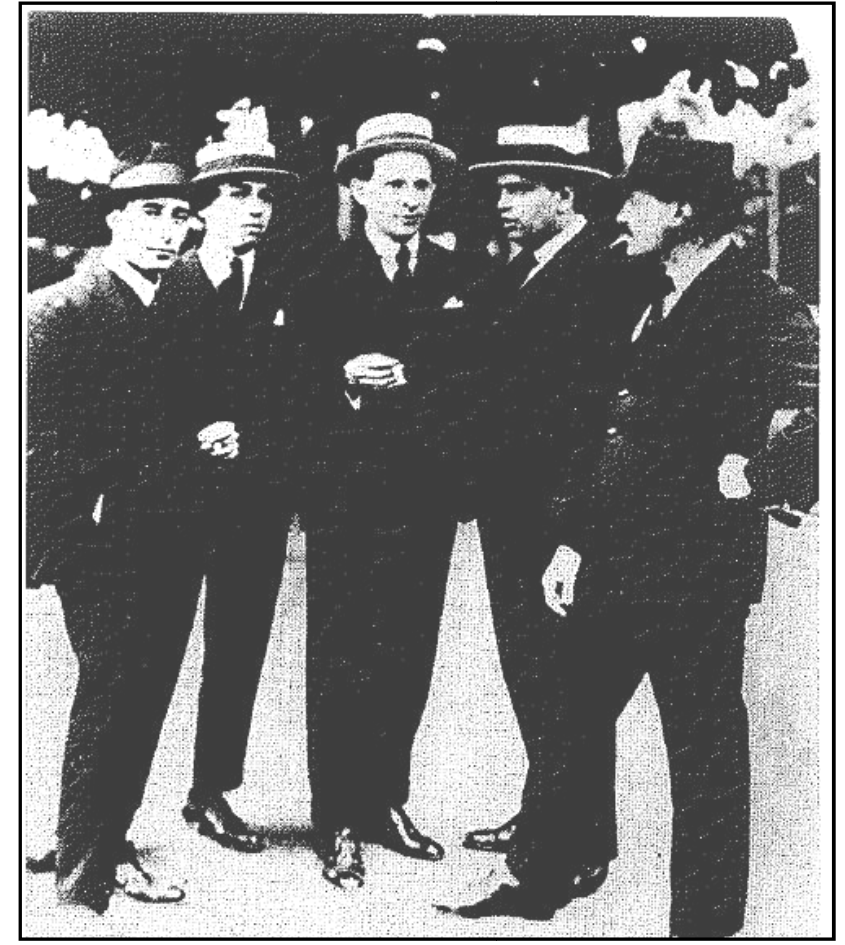

Figura 3.3 - Brecheret e seus descobridores: Di Cavalcanti, Menotti Del Picchia, Oswald de Andrade e Hélios Seeling. Fonte: Batista (1985). paulistanos. Em meio ao movimento modernista, Brecheret propôs a construção de um monumento às bandeiras, tema que partira do escritor Menotti del Picchia.

Picchia afirmava: "Os paulistas relembrariam os heróis de sua terra nas comemorações do Centenário da Independência" (Batista, 1985).

No entanto, a maquete exposta na época (Figura 3.1) não conseguiu atrair patrocínio público nem particular. Exposta a partir de 28 de julho de 1920, na Casa Byington, na Rua 15 de Novembro, n. 26, compareceu à inauguração o Presidente do Estado Washington Luís, acompanhado de seu secretário do interior Alarico Silveira.

Em 1921, as possibilidades de construção do Monumento das Bandeiras se esgotavam, e em Março do mesmo ano, já se sabia que não seria erguido e que Brecheret iria partir (Batista, 1985).

Brecheret então vai a Paris estudar nesta ocasião, onde entra em contato com escultores europeus, como Maillol e Hery Moore. Assim, alterna residência entre Brasil e França até 1936, ainda sendo uma das figuras mais importantes da Semana de Arte Moderna de 1922, expondo algumas de suas esculturas, mesmo estando fora do País (DPH, 2012).

Somente em 1936 é apresentada uma nova proposta ao Governo do Estado de São Paulo. As obras tiveram início no mesmo ano, prosseguindo em ritmo intenso até 1937. Entre os anos de 1938 e 1939 o ritmo da construção é muito reduzido, sendo paralizado nos anos posteriores. Em 1944, o Governador do Estado resolveu transferir a obrigação da 
construção para a Prefeitura de São Paulo, que firmou contrato com o escultor em 1946, e em Maio do mesmo ano é dado início ao processo de confecção da obra (DPH, 2012).

\subsection{A Rocha}

De acordo com o Departamento de Patrimônio Histórico do Município de São Paulo, uma pedreira ofereceu o Granito Itaquera, de granulação fina e duro de desbastar, no entanto esta pedreira tinha dificuldades de fornecer blocos nas dimensões necessárias para a confecção da obra.

A firma Irmãos Milanezi ganha então a concorrência, fornecendo o Granito Mauá (Figuras 3.4 e 3.5) que permitia a retirada de blocos, sendo este granito de granulação mais grossa e menos penoso ao desbaste.

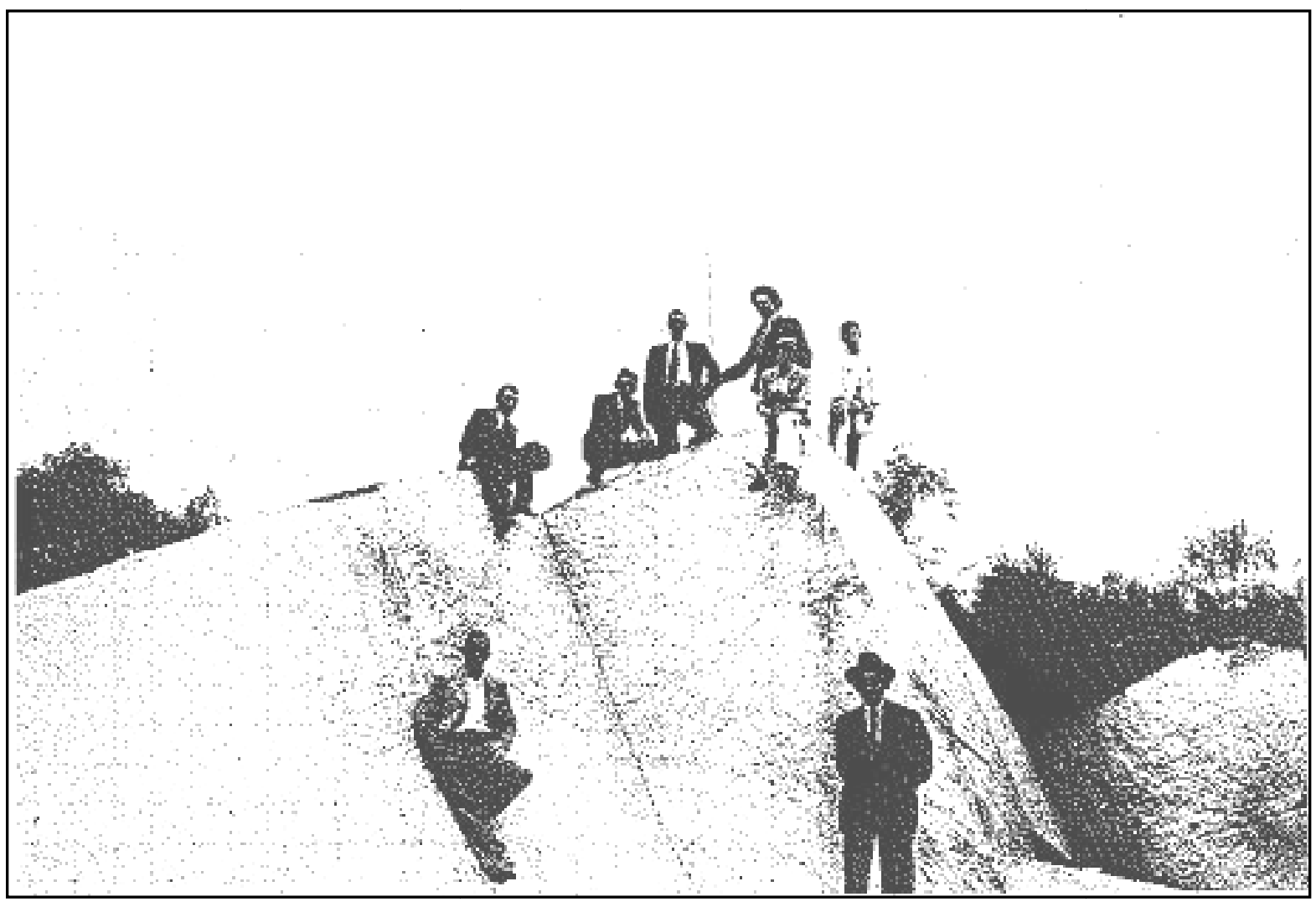

Figura 3.4 - Pedreira Irmãos Milanezi, anos 40. Fonte: Batista (1985). 


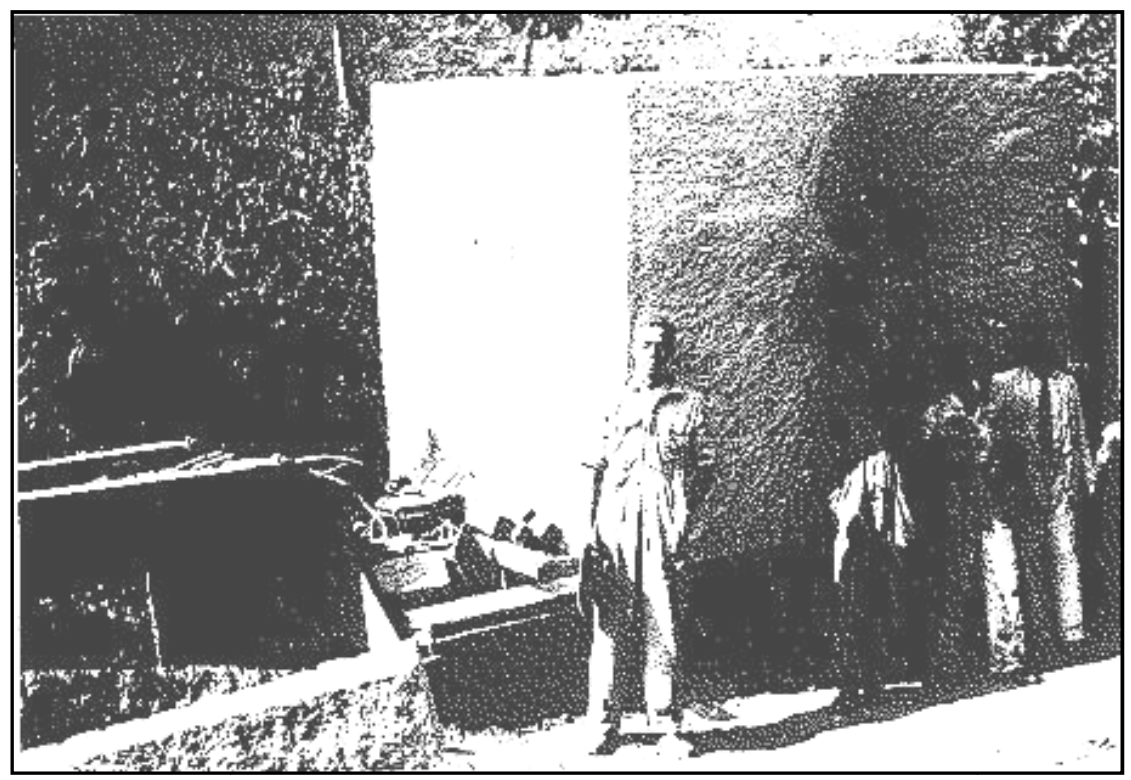

Figura 3.5 - Bloco de granito carregado no caminhão, anos 40. Estrada da Pedreira, Mauá, SP. Fonte: Batista (1985).

\subsection{Implantação do Monumento às Bandeiras}

Os estudos de implantação do monumento na época do projeto apresentaram uma disposição muito próxima daquilo que vemos hoje na Praça Armando Sales de Oliveira. No entanto, na Figura 3.6 vemos que o projeto previa escadarias em volta do monumento e não a base atual. Esta alteração deu-se entre 1949 e 1950. A Figura 3.7 aponta a localização do monumento.

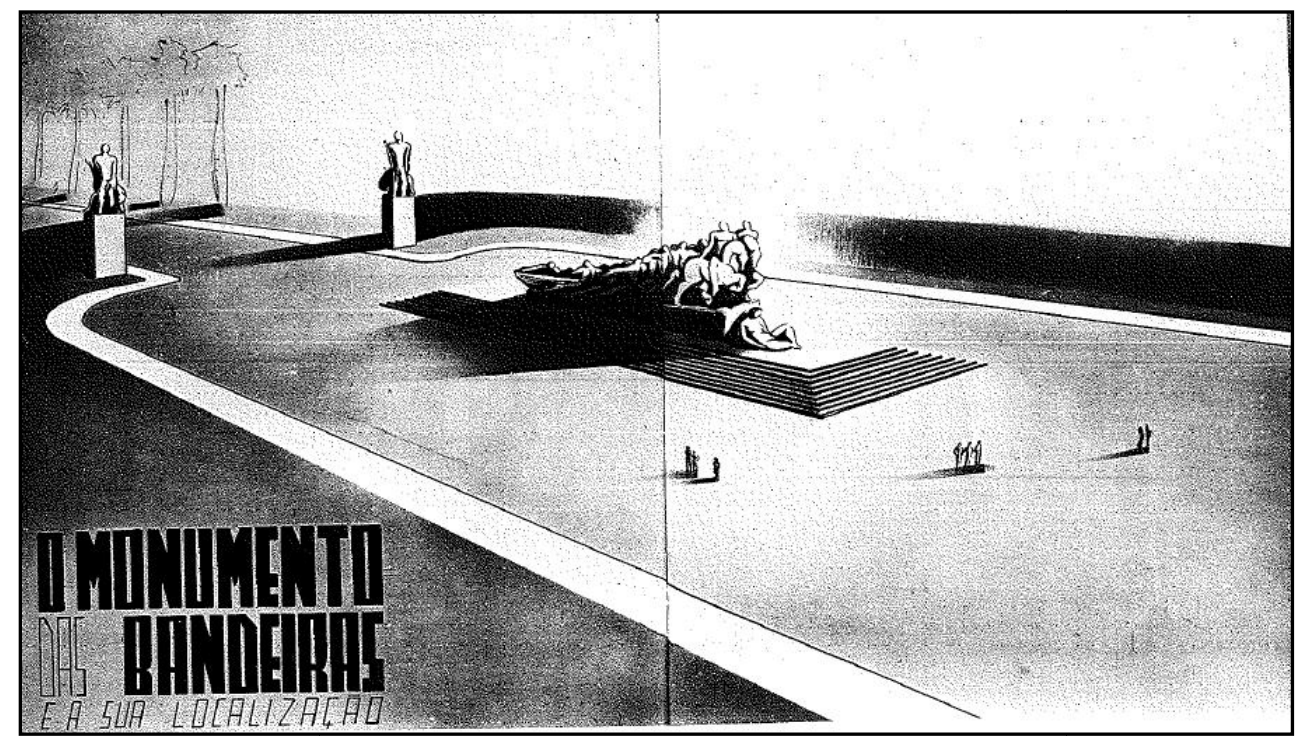

Figura 3.6 - Estudo de implantação do monumento na praça, 1936. Fonte: Batista (1985). 


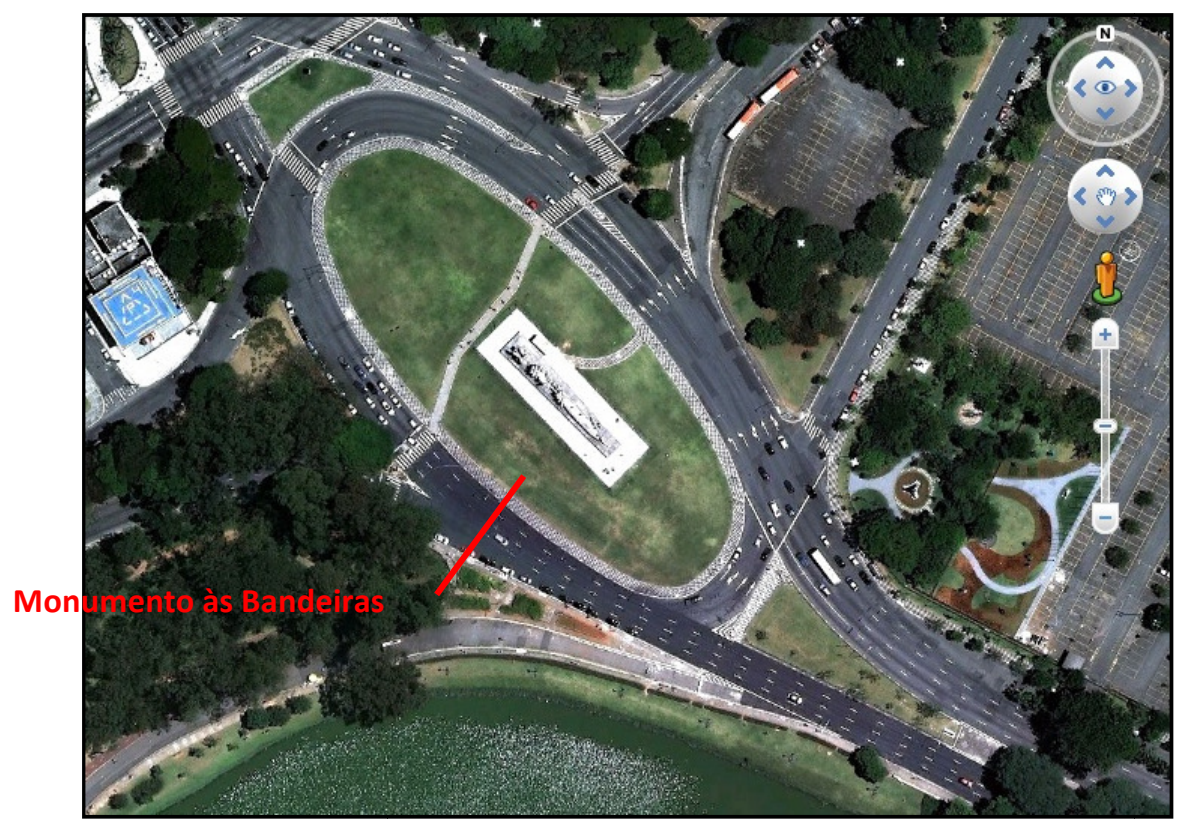

Figura 3.7 - Implantação do Monumento às Bandeiras na Praça Armando Sales de Oliveira, São Paulo SP, Imagem de Satélite Atual. Fonte: Google Maps.

\subsection{Os Modelos}

Auxiliado por vários operários, Brecheret trabalhou entre 1936 e 1937 em um processo complexo e trabalhoso de confecção de modelos previamente às esculturas definitivas em rocha. Foram executados desde maquetes em barro na escala de 1:10 (Figura 3.8), a diversas modelagens em gesso (Figura 3.9), material usado em todas as etapas seguintes (Batista, 1985).

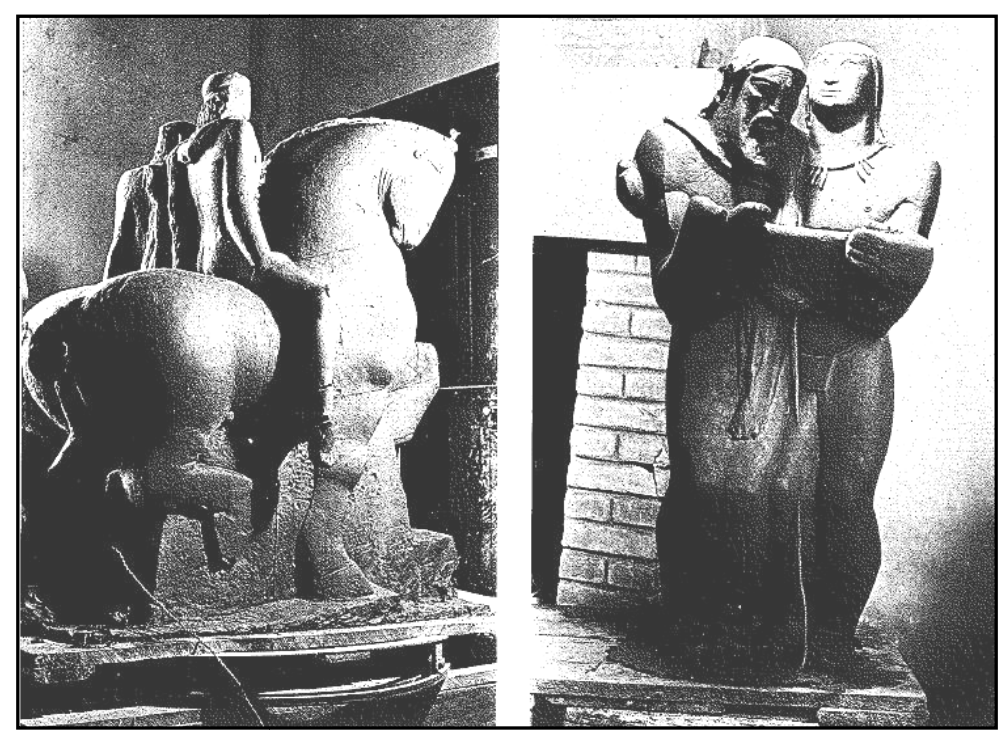

Figura 3.8 - Estudos em Barro. Escala 1:10, 1936 (Cavalos - Esquerda; Imagens - Direita). Fonte: Batista (1985). 


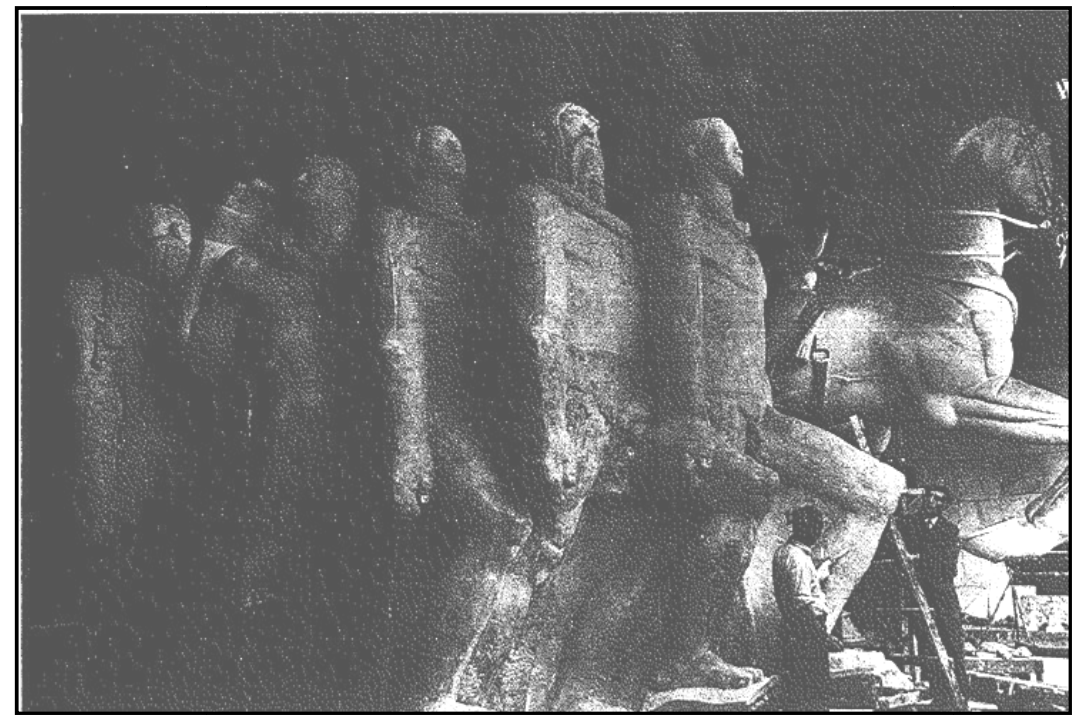

Figura 3.9- Victor Brecheret retocando modelo em gesso do Monumento às Bandeiras, escala 1:1, 1937. Fonte: Batista (1985).

\subsection{A Construção}

Embora as fundações (Figura 3.10) do monumento tenha se iniciado em 1937, a montagem efetiva da obra teve início no ano de 1951, quando a Oficina de Cantaria A. Incerpi e Cia., ganhadora da concorrência para a execução da escultura (Figura 3.11), inicia a montagem do Monumento às Bandeiras como um grande quebra-cabeças, atingindo a impressão final de se tratar de um único bloco de rocha (Figura 3.12). Assim no dia 25 de Janeiro de 1953, um ano antes do quarto centenário da cidade de São Paulo, é inaugurado o Monumento às Bandeiras (Figura 3.13).

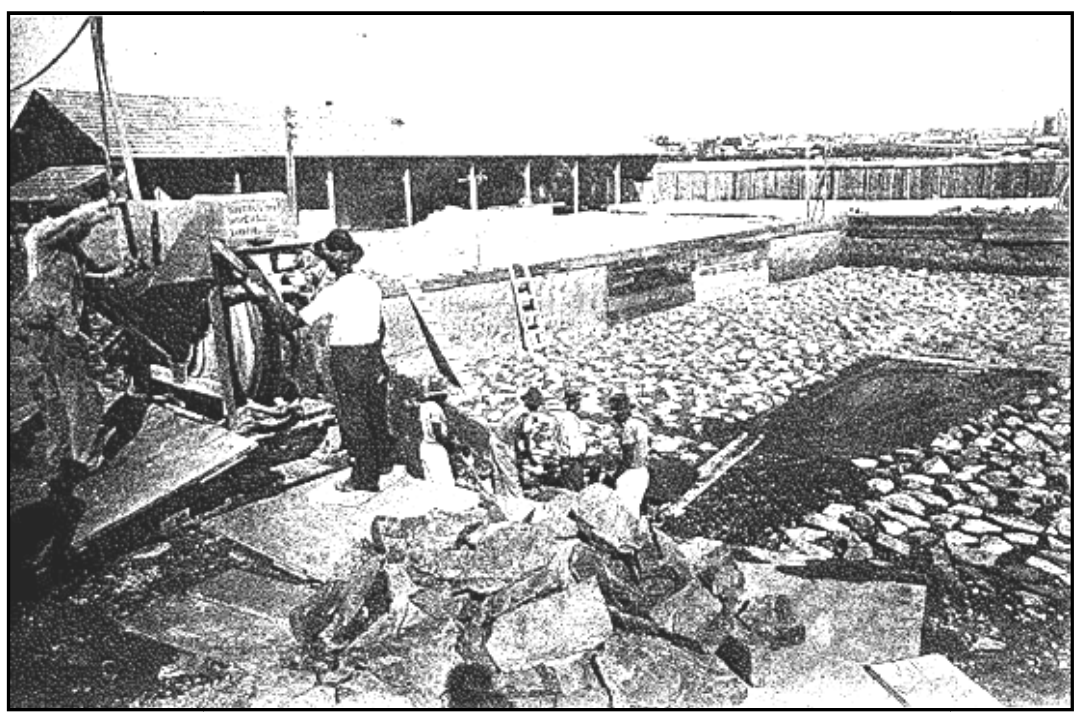

Figura 3.10 - Fundações do Monumento às Bandeiras, 1937. Fonte: Batista (1985). 


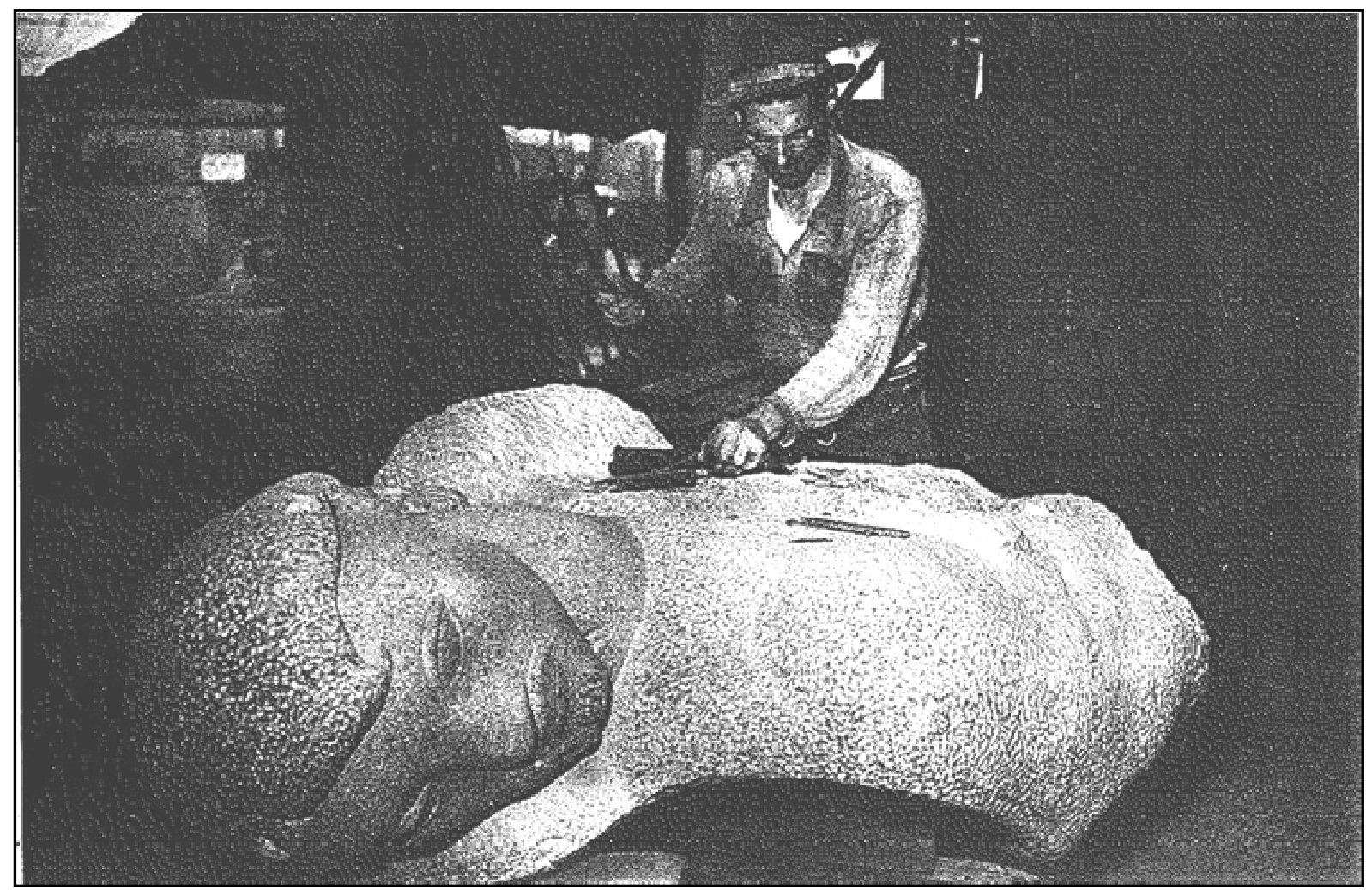

Figura 3.11 - Bloco sendo trabalhado. Oficina Incerpi, fim dos anos 40. Fonte: Batista (1985).

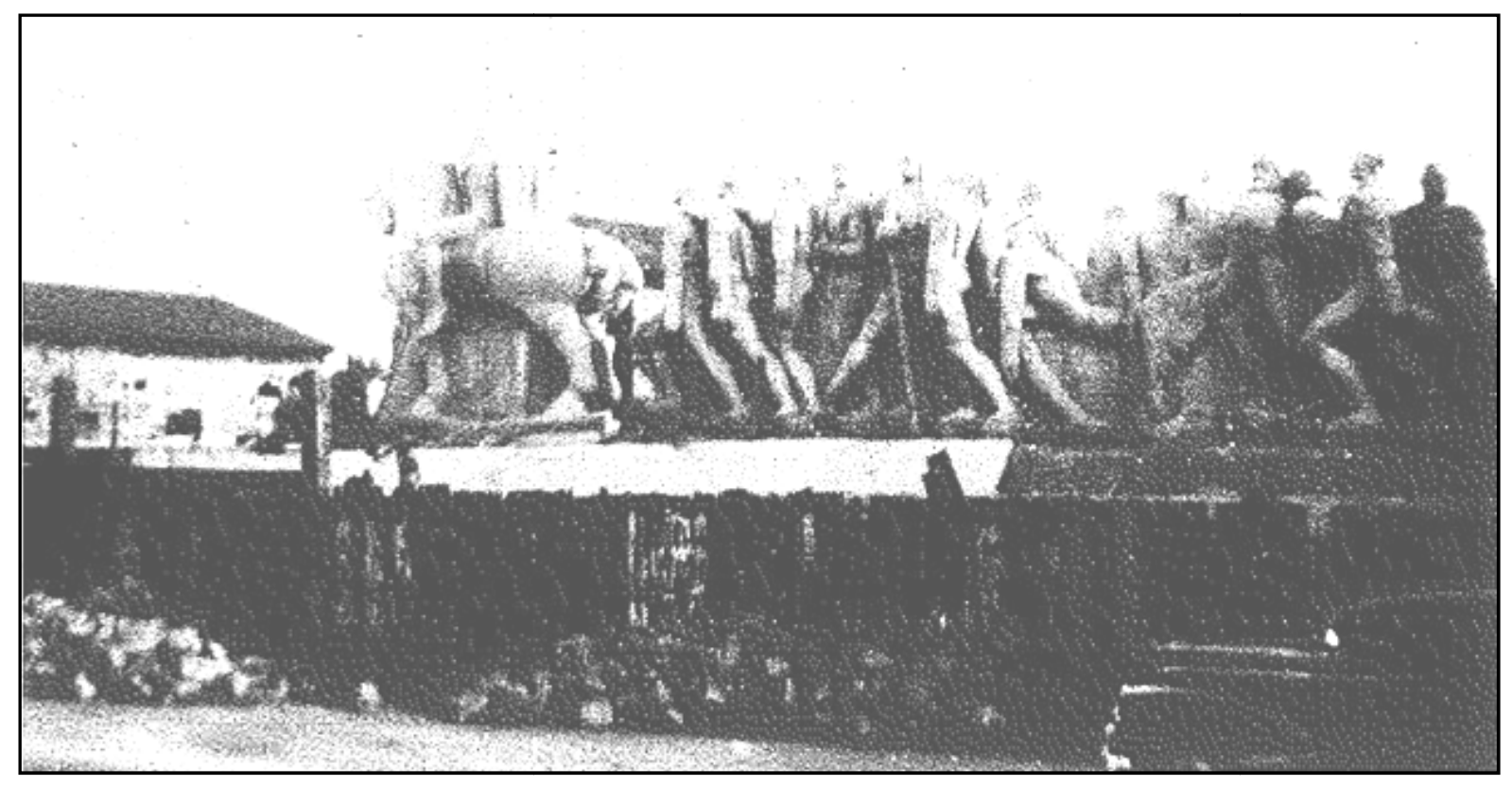

Figura 3.12 - O Monumento às Bandeiras montado. Fonte: Batista (1985). 


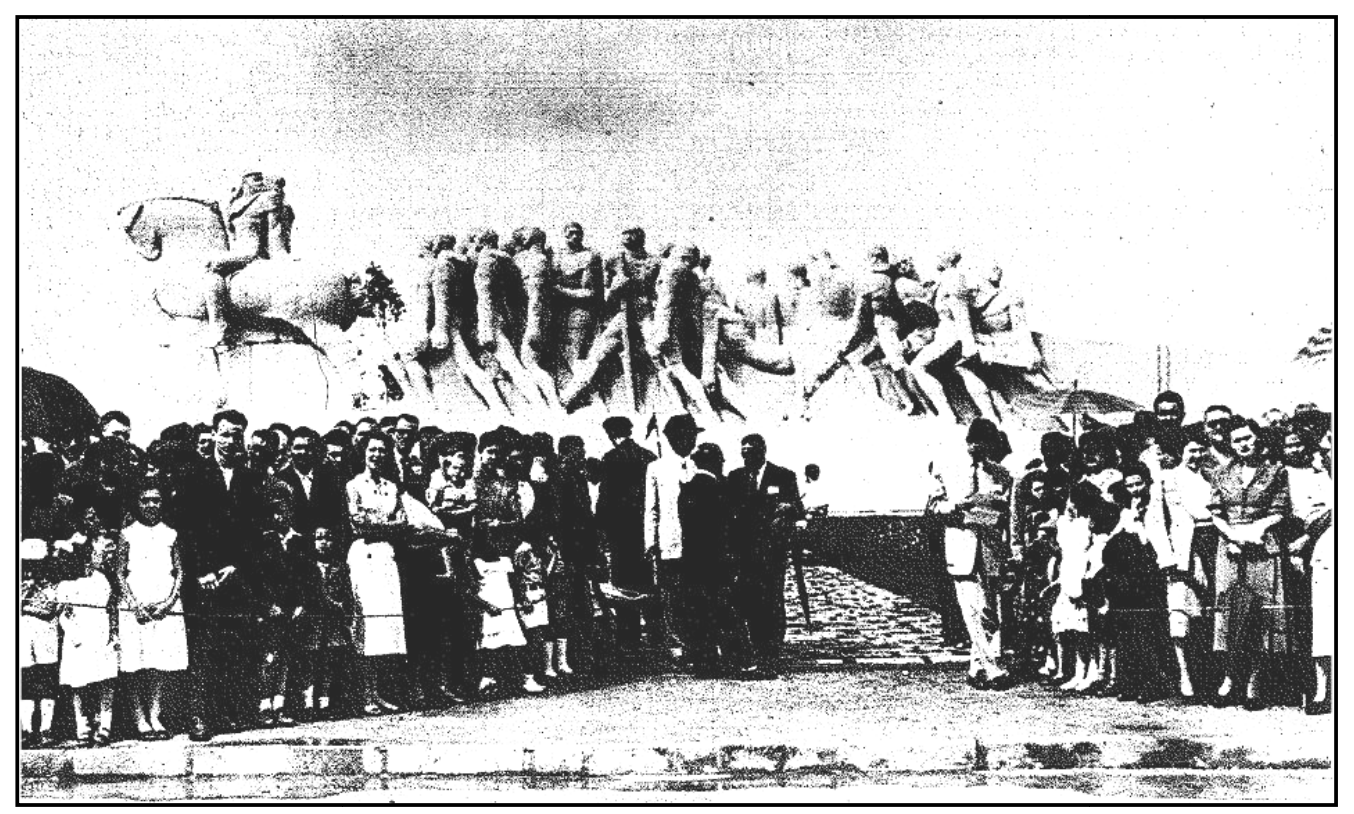

Figura 3.13 - Inauguração do Monumento às Bandeiras, 25 de Janeiro de 1953. Fonte: Batista (1985).

\subsection{Vandalismo}

Embora o Monumento às Bandeiras esteja localizado em um das praças mais movimentadas de São Paulo, são inevitáveis os atos de vandalismo no mesmo.

A segurança do monumento é feita pela polícia civil metropolitana, no entanto, é impossível que a vigilância permaneça integralmente no local, por esse motivo é corriqueiro ver pessoas escalando o monumento com objetivo de posar para fotografias, mesmo sabendo da proibição dessa prática.

Nas Figuras 3.14 a 3.17 podemos verificar alguns dos atos de vandalismo ocorridos no Monumento às Bandeiras nos últimos anos.

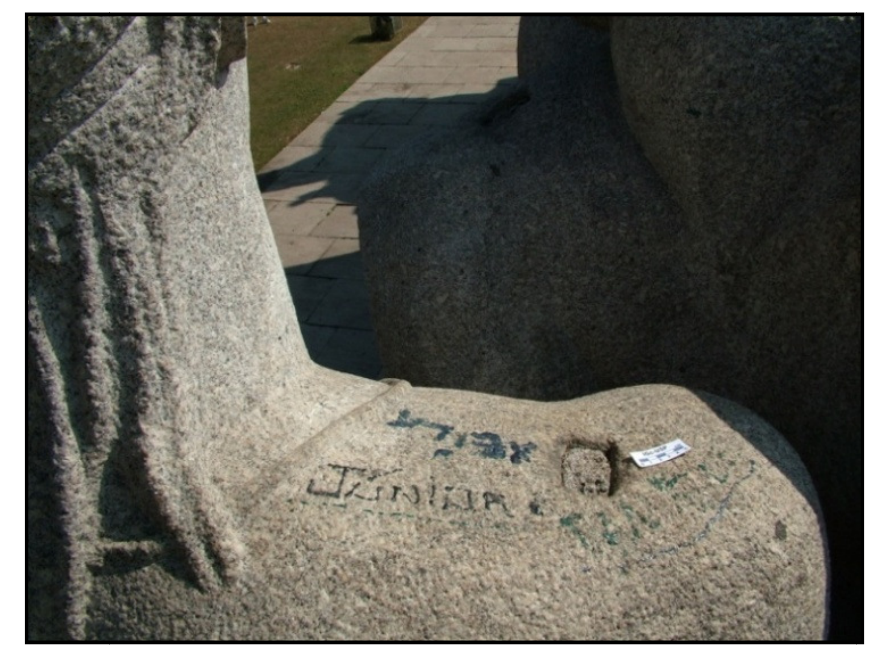

Figura 3.14 - Pichação com tinta no topo do Monumento às Bandeiras. Fonte: Reys (2006). 


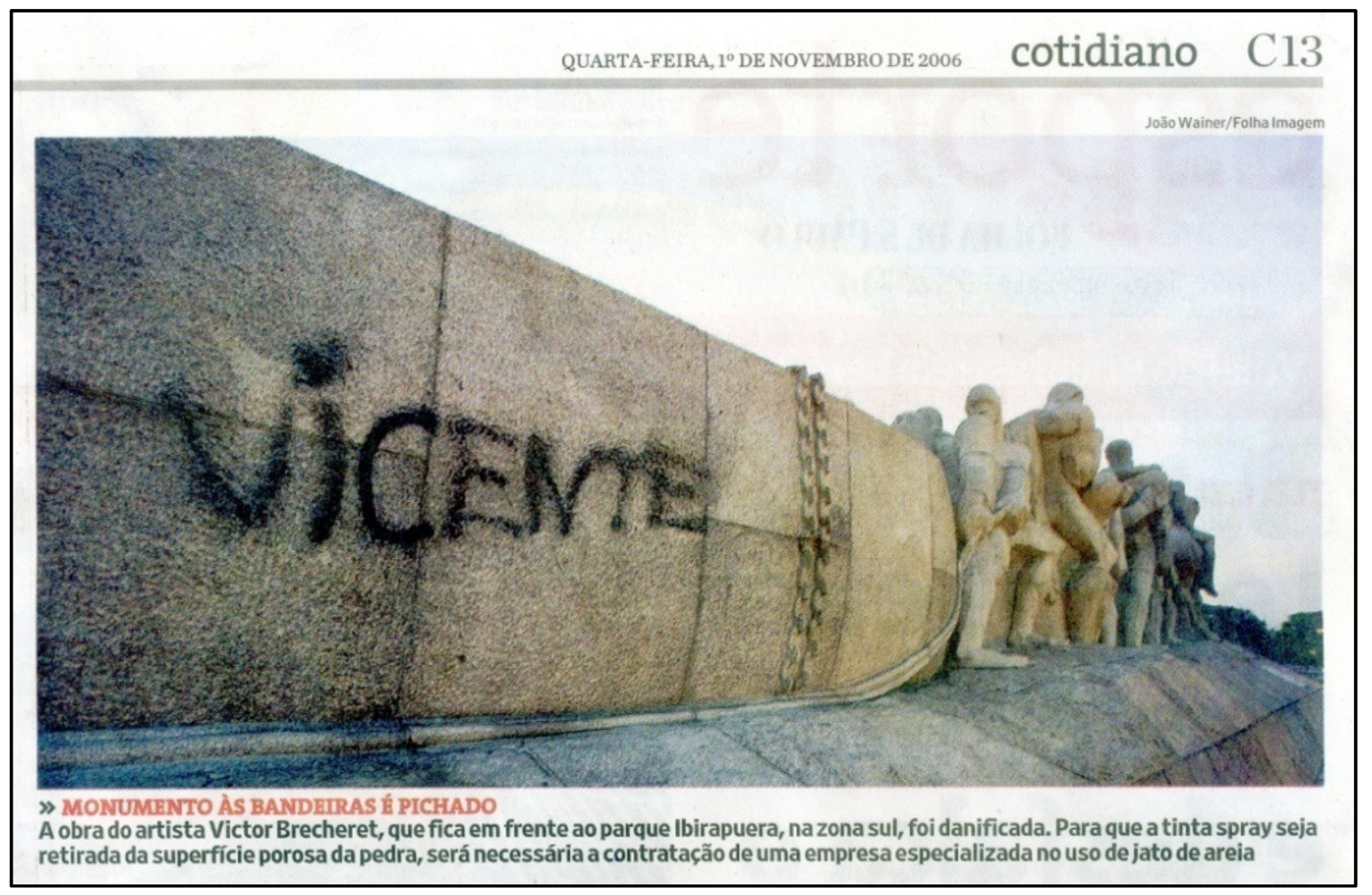

Figura 3.15 - Notícia de Jornal de $1^{\circ}$ de Novembro de 2006 apresentando o barco do Monumento às Bandeiras pichado. Fonte: Jornal Folha de São Paulo - 01/11/2006.

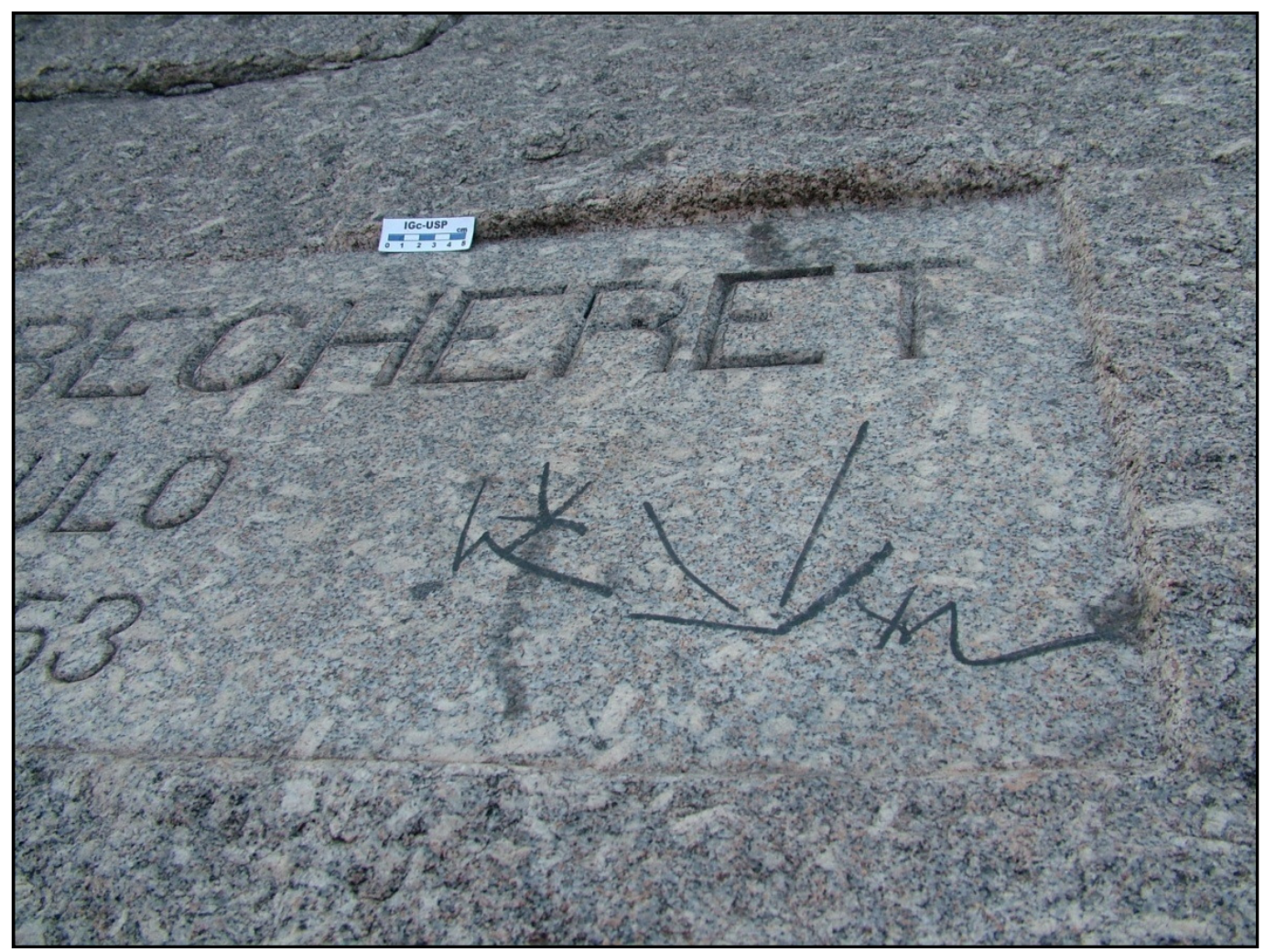

Figura 3.16 - Pichação em placa da base do Monumento às Bandeiras. Foto: Eliane A. Del Lama 13/07/2008. 


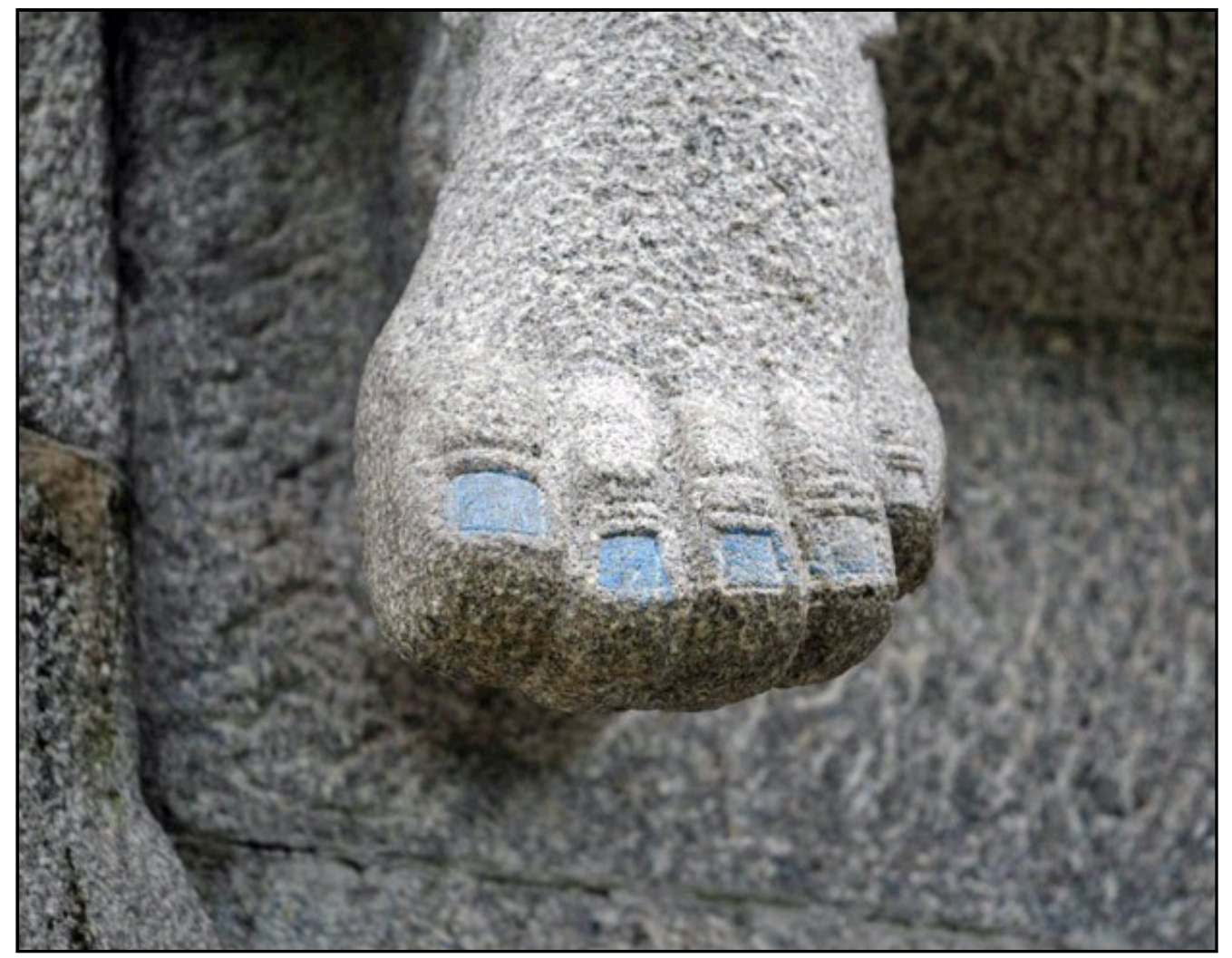

Figura 3.17 - Dois personagens do Monumento às Bandeiras tiveram unhas pintadas. Fonte: g1.globo.com - 15/05/2012. 


\section{Granito Cinza Mauá}

Trata-se de uma das rochas ornamentais mais utilizadas em São Paulo desde as primeiras décadas do século XX (Del Lama et al., 2009). Exemplares desta rocha são encontrados facilmente na região, sendo diversas as suas aplicações, isso por se tratar de rocha ornamental com baixo custo agregado, considerando-se a área fonte a poucos quilômetros da capital e também por não se tratar de um granito exótico.

O Cinza Mauá é um corpo granítico com ocorrência entre os municípios de Mauá e Ribeirão Pires. A Figura 4.1 aponta sua localização e sua abrangência.

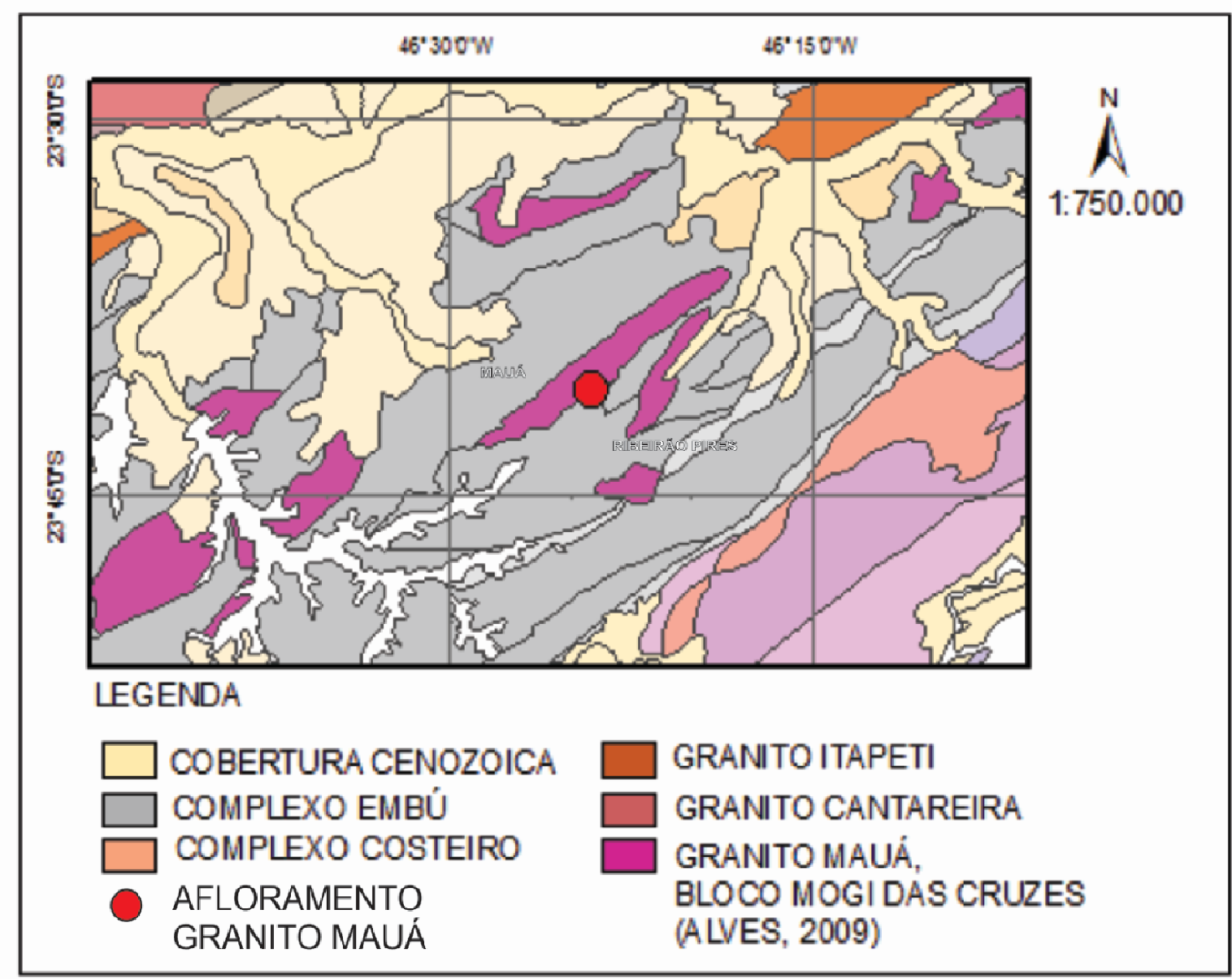

4.1 - Representação litoestratigráficas regional da ocorrência do Granito Cinza Mauá (CPRM, 2006).

Com cerca de 45 km², o Maciço Mauá (Coutinho, 1972; Theodorovicz et al., 1990; apud Alves, 2009) tem forma bastante alongada na direção N45 por 22 km x 2-3 km.

Das utilizações mais conhecidas do Cinza Mauá, excetuando-se sua utilização na confecção de monumentos, estão o calçamento do centro velho de São Paulo e o piso das 
estações de metrô de São Paulo, além de ser encontrado por toda a cidade em utilizações diversas (Figura 4.2).

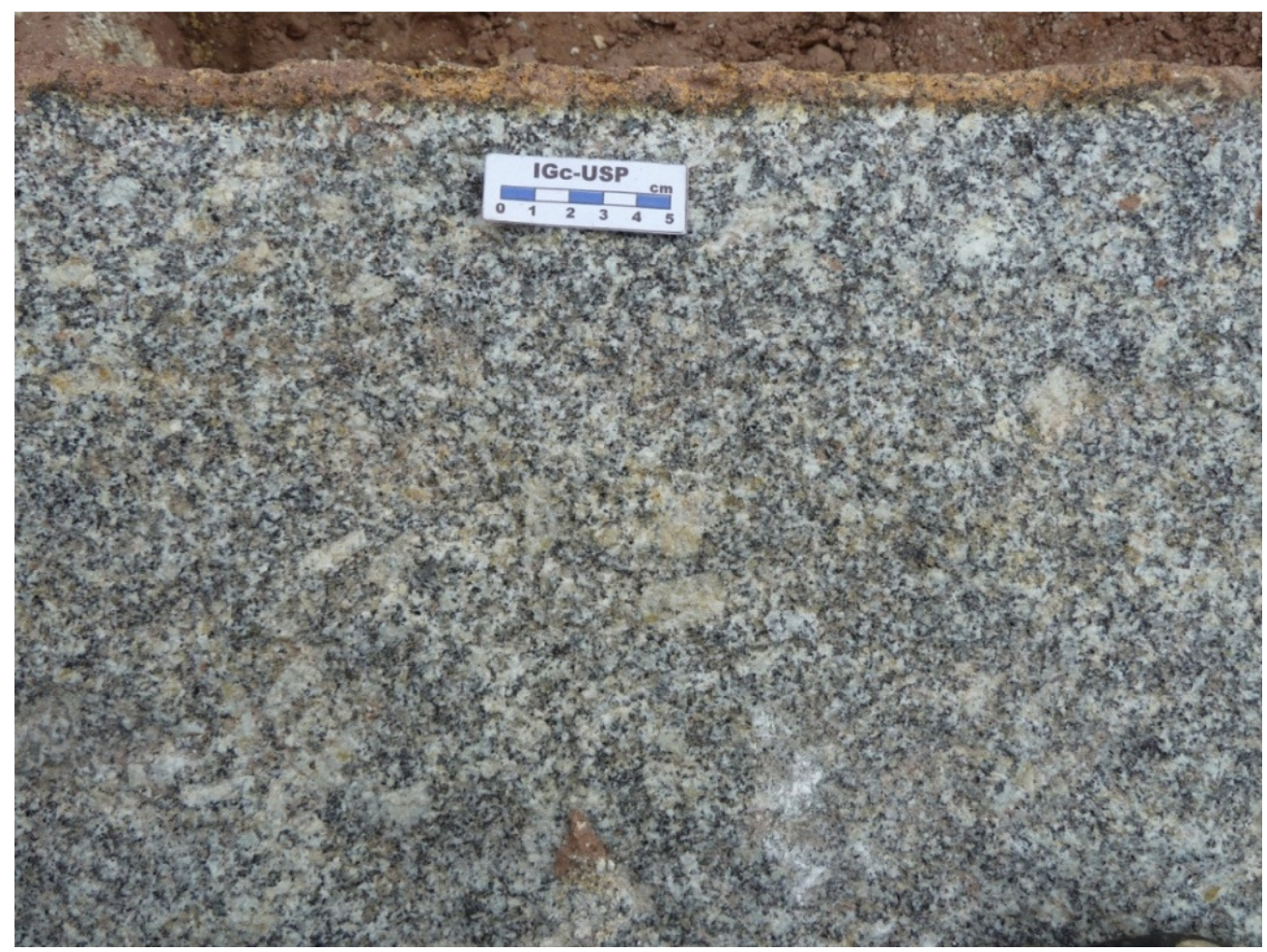

Figura 4.2 - Granito Cinza Mauá - Bloco extraído para cantaria exposto no município de Ribeirão Pires, SP. Foto: Lauro K. Dehira - 30/07/2011.

\subsection{Características do Granito Cinza Mauá}

De acordo com Del Lama et al. (2009), através de avaliação efetuada por microscopia petrográfica, o Granito Cinza Mauá apresenta textura fanerítica porfirítica, sendo constituído por microclínio pertítico (35\%), oligoclásio (30\%), quartzo (28\%), biotita marrom (7\%) e traços de epidoto, allanita, zircão, apatita, titanita, opacos, clorita, sericita e carbonato.

Ainda nesta passagem, os mesmos autores tratam que a biotita, muito presente em enclaves no Granito Cinza Mauá, não apresenta alteração intempérica, o que não provoca degradação dos monumentos por eles estudados.

Augusto (2009) apresenta o Granito Cinza Mauá como um biotita granito com textura fanerítica e estrutura porfirítica, com fenocristais de feldspato com $10 \mathrm{~mm}$ a $15 \mathrm{~mm}$, e matriz de $0,2 \mathrm{~mm}$ a $0,5 \mathrm{~mm}$. 


\subsection{Enclaves}

"Os enclaves mais comuns são microgranulares e de composição granítica. Apresentam IC variável, mas em geral baixo, devendo sua coloração escura à granulometria mais fina que a do granito hospedeiro.

Enclaves metamórficos são geralmente menores, de morfologia ovalada, sem indícios de reação com o hospedeiro; apresentam granulação fina, foliação muito pronunciada e composição de um biotita-gnaisse." (Alves, 2009).

Alves (2009) ainda descreve variedades distintas para os enclaves microgranulares, separando-os em três grupos: enclaves graníticos cinza-médio; enclaves graníticos cinzaescuros e enclaves graníticos brancos, apresentando para estes características composicionais e texturais específicas para cada uma das variedades.

\subsection{Características Físico-Mecânicas}

Abaixo estão representadas as características físico-mecânicas do Granito Cinza Mauá de acordo com o Catálogo das Rochas Ornamentais do Estado de São Paulo do Instituto de Pesquisas Tecnológicas (IPT, 1990).

- Massa Específica Aparente Seca: $2.645 \mathrm{~kg} / \mathrm{m}^{3}$

- Porosidade Aparente: $1,17 \%$

- Absorção de Água: 0,44\%

- Desgaste Amsler: 0,82 mm

- Impacto: $38 \mathrm{~cm}$

- Compressão Uniaxial: 164,4 MPa

- Flexão: 16,2 MPa

- Módulo de Deformabilidade Estático: $44.442 \mathrm{MPa}$

- Coeficiente de Dilatação Térmica Linear: 0,0106 +/- 0,0006 mm/m. ${ }^{\circ} \mathrm{C}$ 


\section{Método de Propagação de Ondas Ultrassônicas}

A utilização do método de propagação de ondas ultrassônicas como método não destrutivo para avaliação de concreto se originou na década de 20, nos Estados unidos as primeiras publicações referentes ao método surgem por volta de 1940 (Bungey,1989; apud Evangelista, 2002).

Considerando-se a aplicação deste método na avaliação de rochas, sabe-se que o mesmo permite avaliar, indiretamente, o grau de alteração e de coesão das rochas, tendo como vantagem ser um dos poucos ensaios não destrutivos, disponível para verificação de propriedades rochosas. Em função disso é especialmente útil para comparação das propriedades físicas entre corpos-de-prova de uma mesma amostra ou entre amostras petrograficamente semelhantes (Frascá, 2003).

A propagação de ondas ultrassônicas é uma metodologia bem difundida e vem sendo utilizado para avaliações de diversos materiais, como madeira, concreto e argamassas, bem como em rochas.

\subsection{Tipos de Ondas}

Para um melhor entendimento do processo envolvido no método de propagação de ondas ultrassônicas é importante que sejam apresentadas as suas características.

De acordo com Serway \& Jewett (2004), a maioria das ondas pode ser subdivida em duas categorias:

- Ondas Mecânicas: São ondas que perturbam e se propagam através de um meio. Todas as ondas mecânicas requerem (1) alguma fonte de perturbação, (2) um meio que possa ser perturbado e (3) algum mecanismo físico pelo qual as partículas do meio possam influenciar outras partículas. Como, por exemplo, as ondas sonoras.

- Ondas Eletromagnéticas: Classe especial de ondas que não requerem um meio para se propagar, as ondas luminosas e de rádio são exemplos destas.

Ainda segundo os mesmos autores, as ondas mecânicas podem se propagar em padrões diferenciados de acordo com fatores condicionantes do meio pelo qual se propagam, podendo ser denominadas de: 
- Ondas transversais: são ondas nas quais as partículas do meio perturbado se movem perpendicularmente à direção da propagação.

- Ondas longitudinais: são ondas nas quais as partículas do meio realizam deslocamentos paralelos ao sentido da propagação. As ondas sonoras no ar, por exemplo, são longitudinais.

Callegari (2006) demonstra esquemas representativos da diferença entre o comportamento das ondas transversais e ondas longitudinais (Figura 5.1).

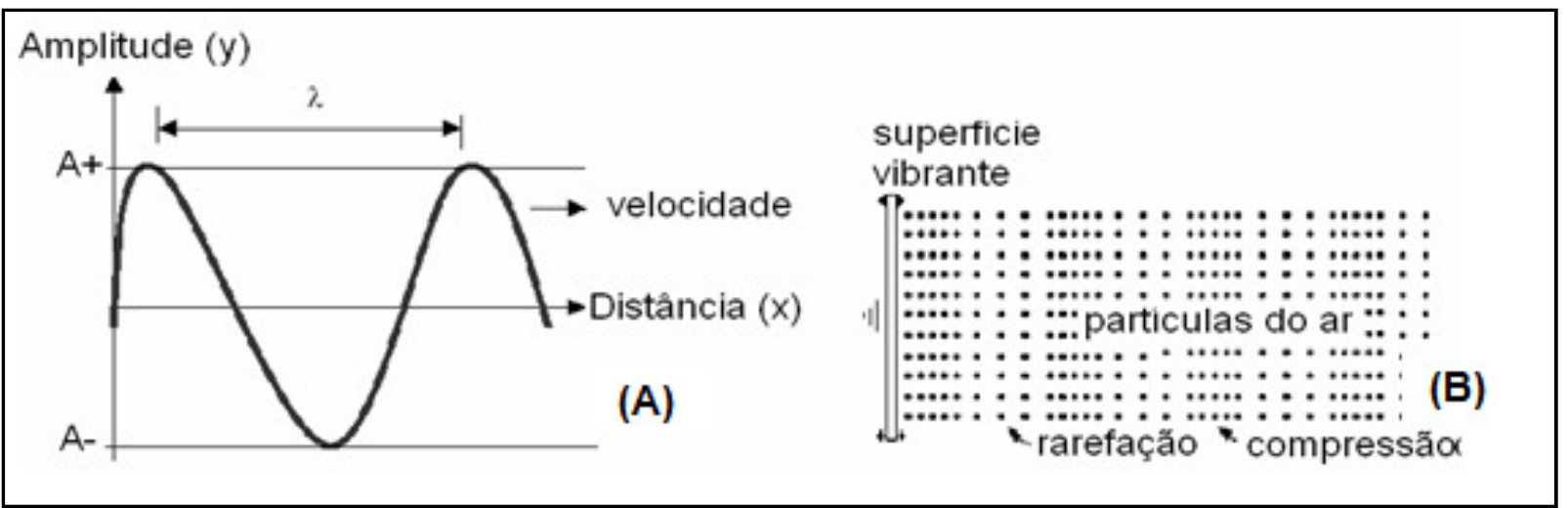

Figura 5.1 - (A) Ondas transversais e (B) ondas longitudinais no ar. Fonte: Calegari (2006).

\section{Ondas Ultrassônicas}

As ondas ultrassônicas são ondas mecânicas, classificadas dentro do grupo das ondas sonoras. O intervalo que compreende as ondas ultrassônicas é definido pelas frequências (f) de $20 \mathrm{kHz}$ a $20.000 \mathrm{kHz}$ sendo $1 \mathrm{~Hz}$ igual 1 ciclo por segundo.

A frequência é descrita pela formula abaixo:

$$
f=1 / T
$$

Onde: $f$ é a frequência; $T$ é o Período. 


\subsection{Equipamentos}

\subsubsection{Aparelho de ensaio por ultrassom}

Para a realização do ensaio de ultrassom é necessário um aparelho capaz de emitir um pulso de um terminal emissor, que é acoplado à amostra que se pretende estudar, o pulso por sua vez atravessa o material que constitui a amostra e é recebido em outro terminal receptor após o percurso pela amostra.

Este aparelho informa o tempo de trânsito entre o terminal emissor e o terminal receptor, esses terminais recebem o nome de transdutores.

Conhecendo-se a distância de ponto a ponto de posicionamento dos transdutores na amostra no momento do ensaio é possível calcular a velocidade de propagação de onda ultrassônica.

Os equipamentos para análises pelo método de propagação de ondas ultrassônicas disponíveis no mercado são similares ao apresentado por Callegari (2006) na Figura 5.2, a grande maioria dos equipamentos possui um display que durante a execução do ensaio apresenta unicamente o valor do tempo de percurso através da amostra.

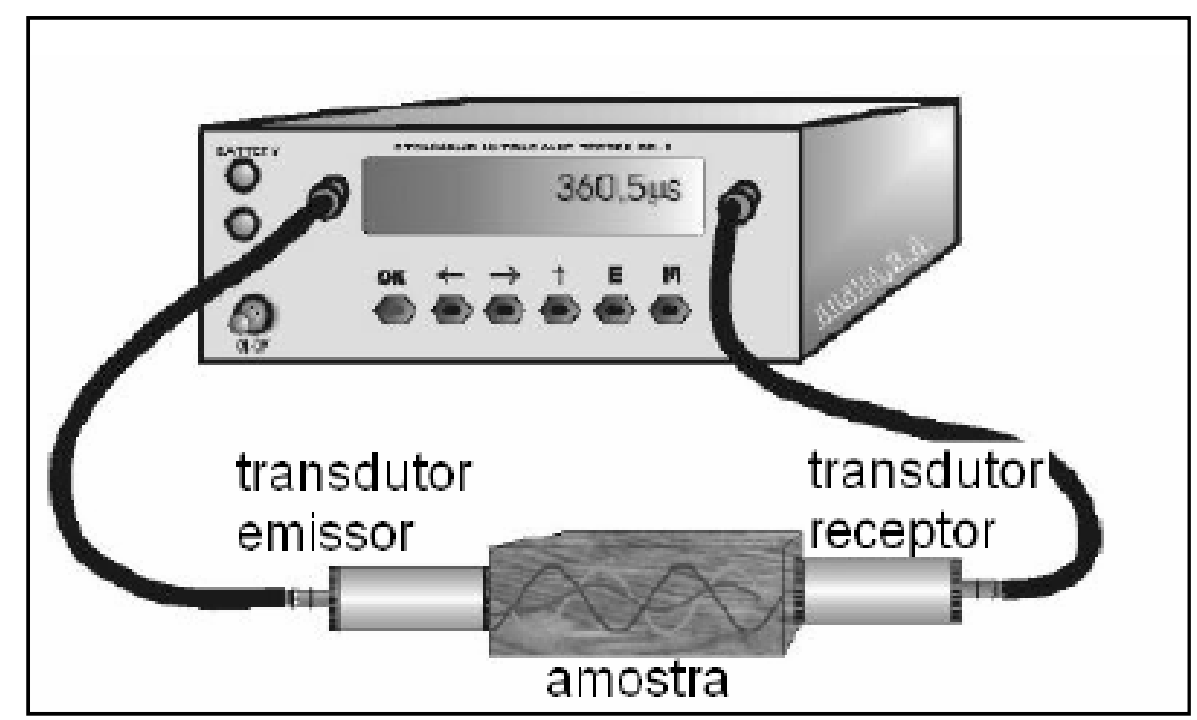

Figura 5.2 - Esquema simplificado de aparelho de ultrassom executando ensaio. Fonte: Callegari (2006).

Novos aparelhos vêm sendo desenvolvidos e se apresentam mais completos, como é o caso do aparelho V-Meter III da James Instruments Inc. (Figura 5.3), que nos possibilita extrair diretamente a velocidade de propagação de ondas ultrassônicas, já que é fornecido o valor da distância, e também apresenta em sua tela o gráfico da onda transmitida. Posteriormente, os dados podem ser salvos em um computador. 
Embora este equipamento, mais avançado, apresente funções que pretendam minimizar o trabalho do operador, foi observado que o mesmo quando conectado aos transdutores exponenciais, fornecidos separadamente ao equipamento pelo mesmo fabricante, não considera o tempo de percurso do pulso através dos cabos e transdutores, assim informando resultados incorretos para essa utilização.

Para calibrar o equipamento na utilização destes transdutores foi necessária a utilização de um osciloscópio que permitiu a determinação do tempo de percurso do pulso nos cabos e transdutores.

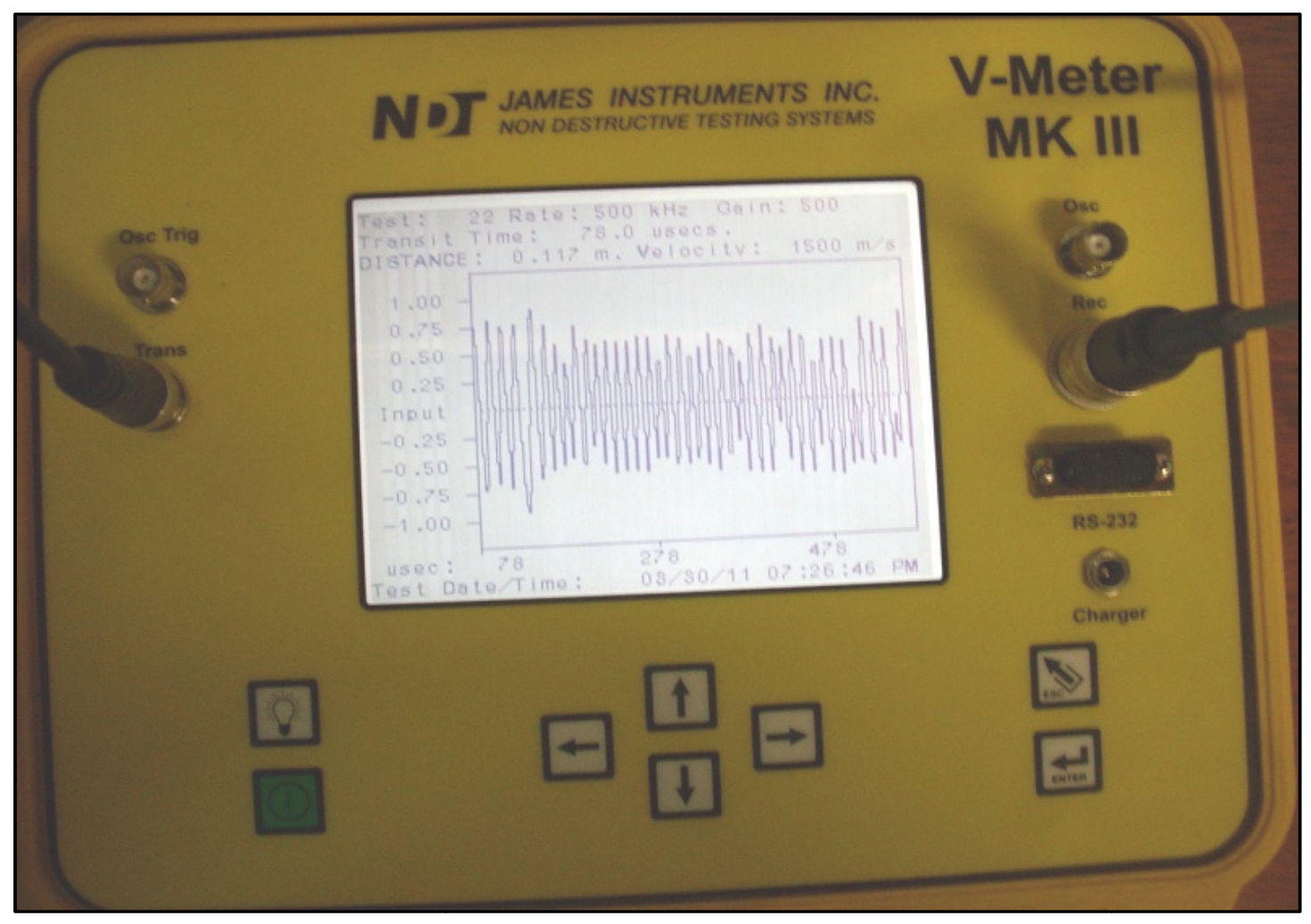

Figura 5.3 - V-Meter III - James Intruments Inc.

O fato de se fornecer ao aparelho a dimensão do corpo a ser analisado previamente a execução das leituras, auxiliaria o operador caso as distâncias entre diversas análises fossem sempre fixas para todas as leituras, no entanto, no estudo desta dissertação isto não ocorreu, pois a cada medida a distância entre os transdutores varia, sendo desfavorável e trabalhoso fornecer a cada análise os dados da distância, sendo que esta situação é ainda mais agravante nas análises de campo.

Quanto à extração dos dados da memória do equipamento para um computador, notou-se que a ferramenta disponibilizada pelo fabricante não favorece a utilização, pois esta simplesmente transfere os dados numéricos para um arquivo de texto (extensão ".txt") 
sem apresentar uma planilha com gráfico e valores organizados favorecendo a compreensão dos dados, como é visualizado na tela da Figura 5.3.

Todos os aparelhos de ultrassom utilizados para esta finalidade são portáteis, o que possibilita o seu uso tanto em laboratório como no campo. Dessa forma é instrumento útil para a avaliação do patrimônio histórico construído em rocha, bem como em outros materiais como madeira, concreto, argamassas, aço, entre outros.

\subsubsection{Transdutores}

Os transdutores são terminais que devem ser conectados por cabos coaxiais ao aparelho de ultrassom, são os responsáveis pela emissão e recepção da onda ultrassônica, e pela conversão do pulso elétrico gerado pelo equipamento em onda ultrassônica. Os transdutores emissores convertem o pulso elétrico em ondas ultrassônicas e os receptores fazem o procedimento inverso.

As altas frequências associadas aos ultrassons podem ser produzidas por vibrações elásticas de um cristal de quartzo induzidas por ressonância com um campo elétrico alterado (efeito piezoelétrico), o transdutor incorpora este elemento piezoelétrico que converte sinais elétricos em vibrações mecânicas gerando a onda do ultrassom (Pelizan, 2004).

Quanto maior a frequência do transdutor, menor o feixe de propagação. A frequência usada para testar concreto e rocha é muito menor do que a usada em metais. As frequências adequadas para aqueles materiais variam de 20 a $250 \mathrm{kHz}$, e a mais usada é a de $50 \mathrm{kHz}$.

\subsubsection{Tipos de Transdutores}

Diferentes tipos de transdutores são utilizados para a avaliação de propagação de ondas ultrassônicas, a escolha e o emprego irão variar de acordo com o tipo de material a ser analisado, as condições e dimensões do mesmo. Os tipos de transdutores são:

- Transdutores planos ou retos: Estes apresentam superfícies planas de contato com as amostras, as diferenças entre um transdutor plano e outro são em suas dimensões e frequências de transmissão. Na Figura 5.4 estão exemplos de dois tipos de transdutores planos, os de $54 \mathrm{kHz}$ com diâmetro de aproximadamente 50 $\mathrm{mm}$ e os de $150 \mathrm{kHz}$ com aproximadamente $22 \mathrm{~mm}$ de diâmetro. 
- Transdutores exponenciais: Estes apresentam superfícies de contato pontuais, com áreas muito reduzidas, sendo recomendados para utilização em leituras sobre superfícies de alta irregularidade ou curvas.

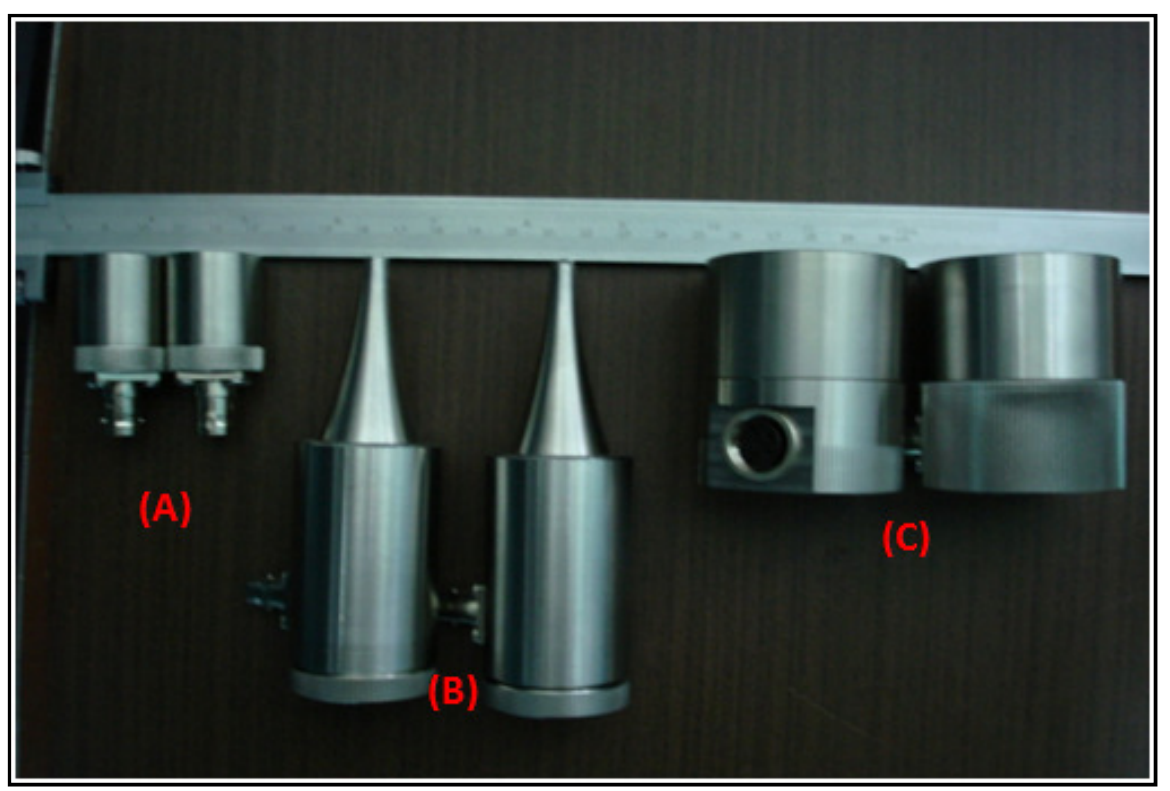

Figura 5.4 - Transdutores - (A) Transdutores Planos de 150 kHz, (B) Transdutores Exponenciais, (C) Transdutores Planos 54 kHz.

\subsubsection{Acoplante}

Acoplante é o nome dado a um material viscoso que auxilia no contato entre o transdutor e a superfície da amostra em análise de forma a permitir a continuidade da onda nessa interface, conforme demonstrado na Figura 5.5. Como acoplante, podem ser empregados diversos materiais como: gel, graxa, glicerina, etc.

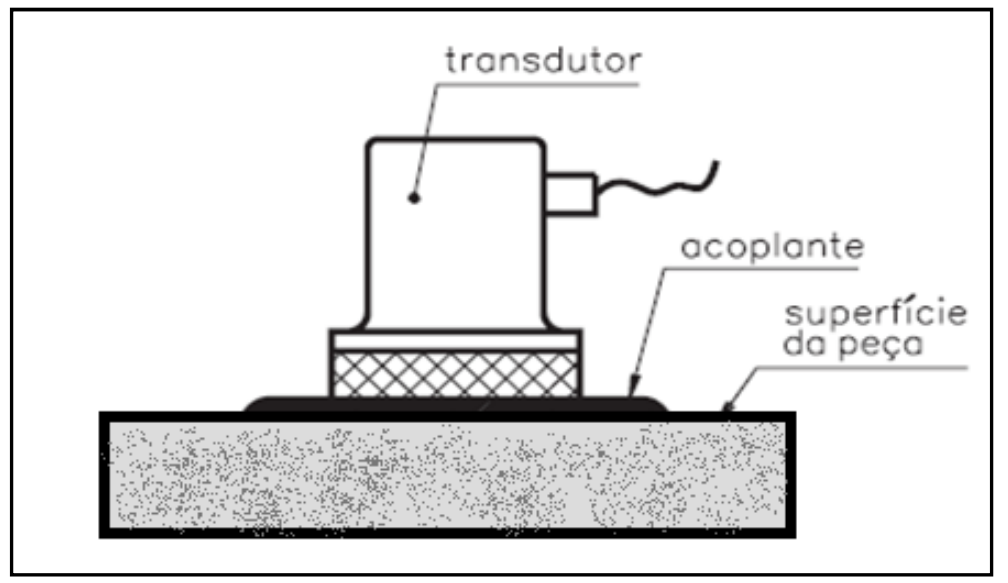

Figura 5.5 - Função do acoplante na interface transdutor/amostra. Imagem adaptada de www.epcapelas.com. 


\subsection{Ensaio de Ultrassom}

Pelizan (2004) descreve os métodos disponíveis para inspeção pelo método de propagação de onda ultrassônica podendo estes ser diferenciados em quatro grupos, dependendo da técnica:

- Técnica do eco pulsado onde é necessário que apenas uma das superfícies do objeto de análise esteja acessível, sendo a análise do fenômeno executado por reflexão, devido às descontinuidades ou à interface da peça. Geralmente é utilizado um único transdutor (emissor/receptor) ou os dois transdutores na mesma superfície.

- Técnica da ressonância que se baseia na frequência fundamental de vibração da amostra; esta é mensurada pelo aumento brusco da amplitude, que ocorre quando o comprimento de onda, ou um múltiplo de meio comprimento, iguala a espessura da peça analisada.

- Técnica da transmissão é a mais usada, é a que se aplica ao equipamento descrito neste trabalho. Consiste na utilização de dois transdutores (um transmissor e outro receptor) em duas faces opostas ou não da amostra.

- Técnica de imersão é semelhante às técnicas de eco pulsado ou de transmissão, a principal característica que difere das outras técnicas é o fato do corpo a ser analisado ficar imerso em água, neste caso, a água elimina a necessidade da utilização de acoplante.

Dentre as técnicas acima descritas o método que melhor se aplica ao estudo do patrimônio histórico construído em rocha é a técnica da transmissão.

O ensaio pela técnica da transmissão nos fornece o tempo de trânsito da onda ultrassônica de um ponto a outro da amostra estudada. No entanto, existem formas diferenciadas no posicionamento dos transdutores, é o que denominamos tipos de transmissão. 


\subsubsection{Tipos de Transmissão}

Contamos com três formas de transmissão para a execução das leituras com 0 ultrassom (Figura 5.6) de acordo com a ABNT NBR 8802/94. São elas:

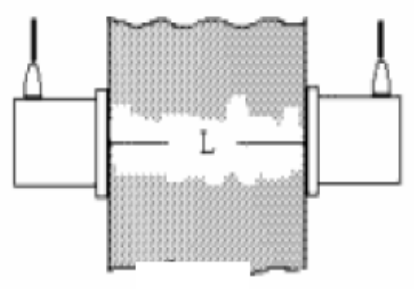

(A)

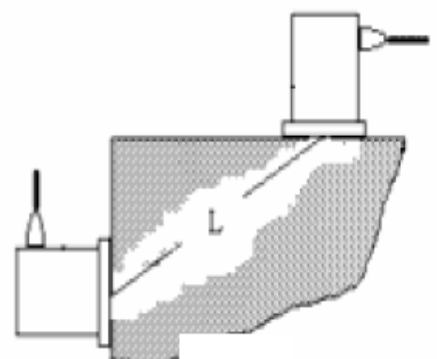

(B)

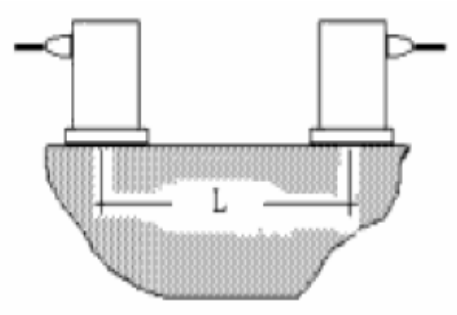

(C)

Figura 5.6 - Tipos de Transmissão. Fonte: Callegari (2006).

(A) Transmissão Direta - Os transdutores são colocados em faces opostas do material.

(B) Transmissão Semidireta - Colocam-se os transdutores em faces perpendiculares.

(C) Transmissão Indireta - Consiste no posicionamento dos transdutores em uma mesma face.

A transmissão direta é o método mais sensível, pois o transdutor-receptor recebe a maior energia do pulso transmitido, uma vez que os pulsos longitudinais são propagados predominantemente na direção normal à face do transdutor-emissor, e em seguida a transmissão semidireta é o segundo melhor método, sendo a transmissão indireta o método menos eficiente, pois para um mesmo comprimento a amplitude recebida é somente cerca de $2 \%$ do sinal recebido em comparação à transmissão direta (James Instruments Inc., 2010).

A escolha do tipo de transmissão deve ser efetuada de acordo com o objeto da análise, sempre que possível deve se optar pelo método da transmissão direta, quando for impossível o uso da transmissão direta e o objeto apresentar ao menos duas faces disponíveis para análise deve se optar pela transmissão semidireta e somente em último caso utilizar o método da transmissão indireta.

Nunca devem ser analisados juntamente valores de diferentes tipos de transmissão, pois de um tipo de transmissão para outro existe uma perda considerável do sinal da onda ultrassônica, estes devem ser considerados separadamente. 


\subsubsection{Procedimento de ensaio}

Antes de iniciar o ensaio é necessário levantar previamente os itens abaixo:

a) Escolha do objeto de estudo: É necessário saber se a amostra será estudada no laboratório ou se será necessário o deslocamento até o objeto para realizar as medidas.

b) Definir qual o transdutor deve ser utilizado, dadas as dimensões do objeto e condições superficiais para acoplagem.

c) Determinar o tipo de transmissão mais adequado ao objeto, neste caso é importante buscar o tipo de transmissão que melhor possa ser empregado em toda a peça.

Após levantar os dados acima, devem-se iniciar os ensaios. A análise consiste em:

- Conectar os transdutores previamente escolhidos ao aparelho de ultrassom, o aparelho se encarregará de enviar o pulso elétrico até o transdutor emissor, para que seja gerado o pulso ultrassônico.

- O transdutor emissor deve estar devidamente acoplado à amostra, com o auxílio do acoplante para regularização do contato com a base da amostra.

- O pulso emitido pelo transdutor emissor percorrerá a amostra até alcançar a superfície onde se encontra o transdutor receptor.

- O transdutor receptor também devidamente acoplado à amostra, com o uso do acoplante, recebe a onda após o tempo de percurso na amostra, assim transformando o pulso ultrassônico novamente em elétrico, enviando-o ao aparelho.

- O aparelho recebe o pulso elétrico e calcula o tempo de percurso da onda através da amostra, apresentando este tempo no painel digital. Alguns aparelhos apresentam o valor da velocidade de propagação da onda ultrassônica em seu painel, desde que a distância seja inserida no aparelho previamente ao ensaio.

O procedimento descrito tem por objetivo a determinação da velocidade de propagação da onda ultrassônica através do corpo avaliado. Para tal determinação, as distâncias entre os transdutores devem ser medidas na amostra com o máximo de precisão possível, indica-se o uso de paquímetro, ou equipamento capaz de garantir a precisão mínima de 0,1 mm, conforme sugerido pela norma norteamericana ASTM D2845/00. 
Após a determinação do tempo de percurso e distância entre os transdutores, a velocidade de propagação da onda ultrassônica deve ser calculada pela formula da velocidade:

$$
V=\frac{L}{t}
$$

Onde:

$V$ é a velocidade em metros por segundo $(\mathrm{m} / \mathrm{s})$.

$L$ é a distância entre os pontos de acoplagem dos transdutores em (m).

$t$ é o tempo em segundos (s).

\subsection{Exemplos de utilização do método}

\subsubsection{Usos em materiais diversos}

O método de propagação de ondas ultrassônicas vem sendo largamente utilizado para diversas avaliações. A seguir estão expostos alguns exemplos de estudos que utilizaram este método em pesquisas diversas.

Ziegler \& Carmo (2003) utilizam o método para inspeção e manutenção de estruturas em concreto armado, de acordo com o procedimento prescrito pela norma brasileira ABNT NBR 8802/94, expondo que a determinação da velocidade de propagação da onda ultrassônica auxilia na detecção de fissuras e falhas de adensamento do concreto, pelo fato do ar não se tratar de bom condutor (Figura 5.7).

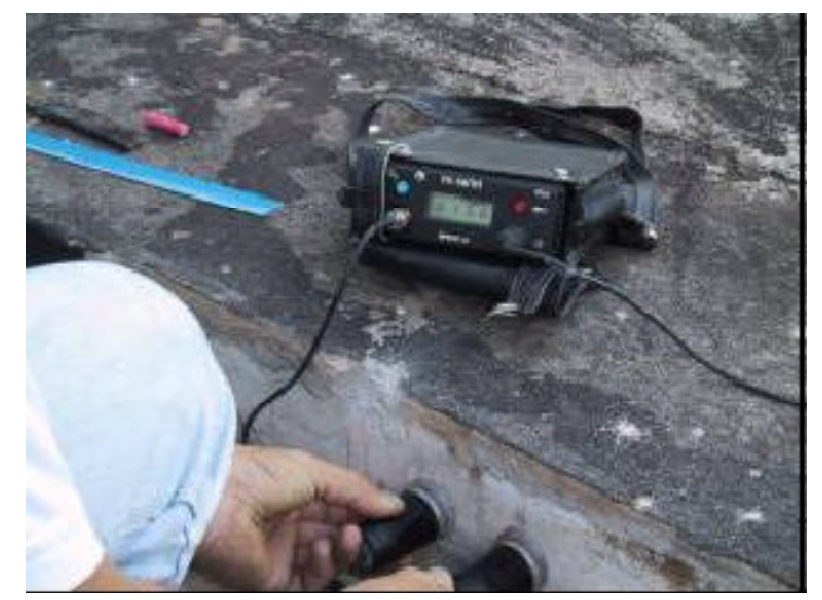

Figura 5.7 - Inspeção de concreto armado pelo método de ultrassom. Fonte: Ziegler \& Carmo (2003). 
Pelizan (2004) aplica o método do ultrassom para a determinação do módulo de Young em toras de madeira, executando avaliações longitudinais e transversais pelo método da transmissão direta utilizando transdutores exponenciais. A autora refere-se a estes transdutores como transdutores ultrassônicos de contato puntual.

Calegari (2006) utiliza o método como forma de controle do processo de secagem da madeira, utilizando transdutores planos e transdutores exponenciais com frequência de aproximadamente $50 \mathrm{kHz}$ com diâmetro útil de $2,5 \mathrm{~mm}$, considerando que os transdutores exponenciais são dotados de extensores, que partem de uma superfície plana para um adaptador e permite análises pontuais, assim denominados pelo autor de transdutores de ponto seco (Figura 5.8).

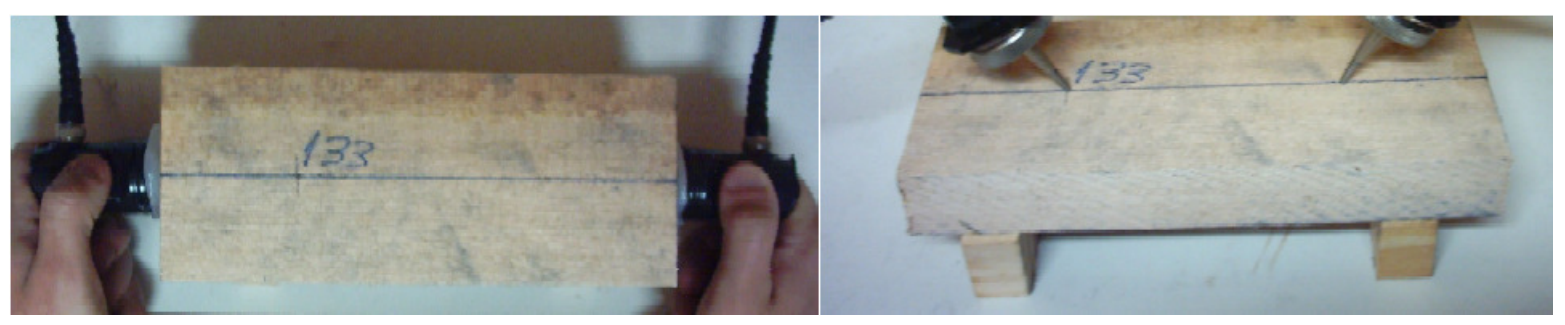

Figura 5.8 - Imagens da análise ultrassônica no controle de secagem de madeiras. Transdutores de faces planas [Esquerda] e transdutores de ponto seco [Direita]. Fonte: Calegari (2006).

\subsubsection{Usos em estudos de rochas}

Rossi-Manaresi \& Tucci (1983) utilizam o método para a avaliação da eficiência de aplicação de consolidantes em arenito. Esta avaliação trata a consolidação do arenito presente nas colunas do Palazzo Gaudenzi, construção do século XVI. Neste estudo, os autores efetuaram analises in loco da propagação da onda ultrassônica pelas transmissões direta e semidireta. Em laboratório, analisaram a mesma rocha que compõe o Palazzo Gaudenzi para a determinação das consequências do tratamento.

Topal \& Doyuran (1995) avaliam o tufo da Capadócia, Turquia, utilizando o método ultrassônico para a determinação do comportamento da rocha em simulação intempérica de ciclos de saturação em água e secagem, congelamento e degelo e cristalização salina. Para esta avaliação os autores utilizaram transdutores de $63 \mathrm{~Hz}$ para determinação das ondas longitudinais e transdutores de $100 \mathrm{kHz}$ para determinação das ondas transversais.

Köhler et al.(1996) aplicam o método de propagação de ondas ultrassônicas no portal oeste da catedral de St. Stephen em Viena. Nessa avaliação levantam por volta de mil pontos de leitura, abordando quase toda a rocha que compõe o portal, as distâncias entre as leituras foram de 1,5 a $60 \mathrm{~cm}$ e a frequência utilizada para a avaliação foi de $250 \mathrm{kHz}$. 
Almesberger et al. (2000) avaliam em laboratório o calcário Pietra D’lstria, oriundo da península de Istria (Itália), presente em aproximadamente $80 \%$ dos monumentos e construções de Veneza. Em função da anisotropia presente na rocha, utilizam o método de propagação de ondas ultrassônicas tanto no sentido paralelo à estrutura, como no perpendicular. No estudo em questão utilizam tanto transdutores de $55 \mathrm{kHz}$ como de 120 $\mathrm{kHz}$, e afirmam que os transdutores com maior frequência apresentaram-se mais sensíveis aos distúrbios gerados na onda em função de defeitos nas amostras, optando assim por obter a velocidade com transdutores de $120 \mathrm{kHz}$.

Papida et al. (2000) utilizam o método de propagação de ondas ultrassônicas na avaliação da ação física e microbiana aplicado a corpos de prova de dois calcários de Creta, Grécia e um dolomito do Reino Unido durante estudo de aceleração intempérica, combinando água, soluções de $\mathrm{NaCl}$ e $\mathrm{Na}_{2} \mathrm{SO}_{4}$ com populações microbiológicas.

Sheremeti-Kabashi \& Snethlage (2000) determinam a estrutura anisotrópica de seis amostras cúbicas de Mármore Carrara com transdutores de $46 \mathrm{kHz}$, através de avaliações angulares da propagação de ondas ultrassônicas.

Maia (2004) utiliza o método do ultrassom como técnica de avaliação de rochas ornamentais. Submete amostras de laboratório de duas espécies de granito ao procedimento prescrito pela norma norteamericana ASTM 2845/95, efetuando as leituras pela transmissão direta e utilizando transdutores de $54 \mathrm{kHz}$ (Figura 5.9).

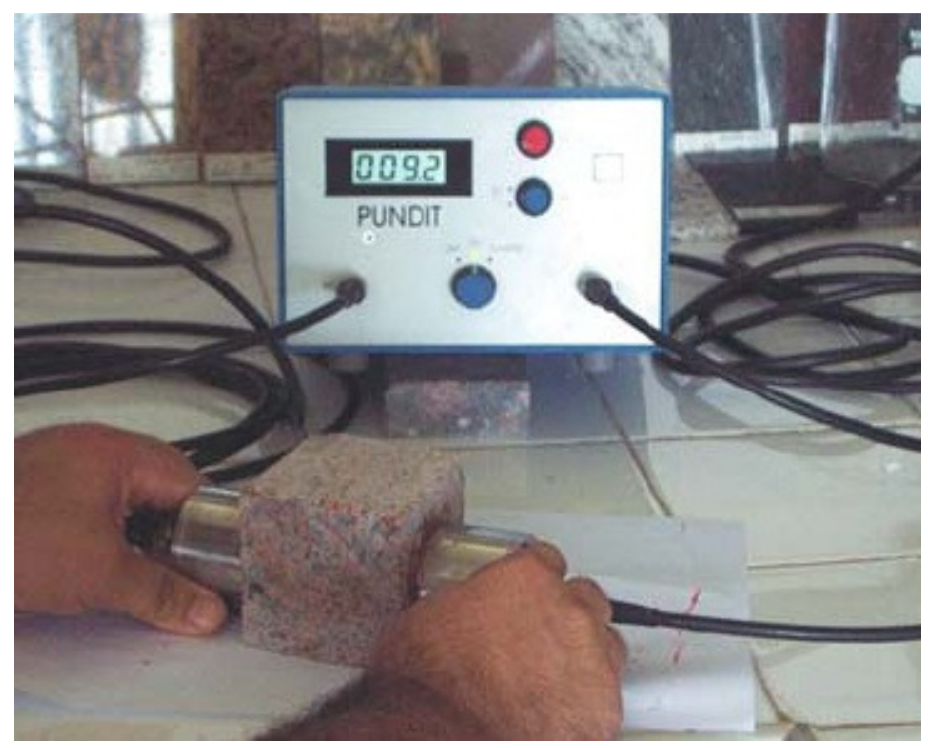

Figura 5.9 - Execução de ensaio em laboratório em granito. Fonte: Maia (2004).

Fitzner (2004) apresenta o estudo de um monumento em rocha, onde executa o mapeamento das velocidades de propagação de ondas ultrassônicas, complementando o mapeamento das formas de alteração da rocha que o compõe (Figura 5.10). 


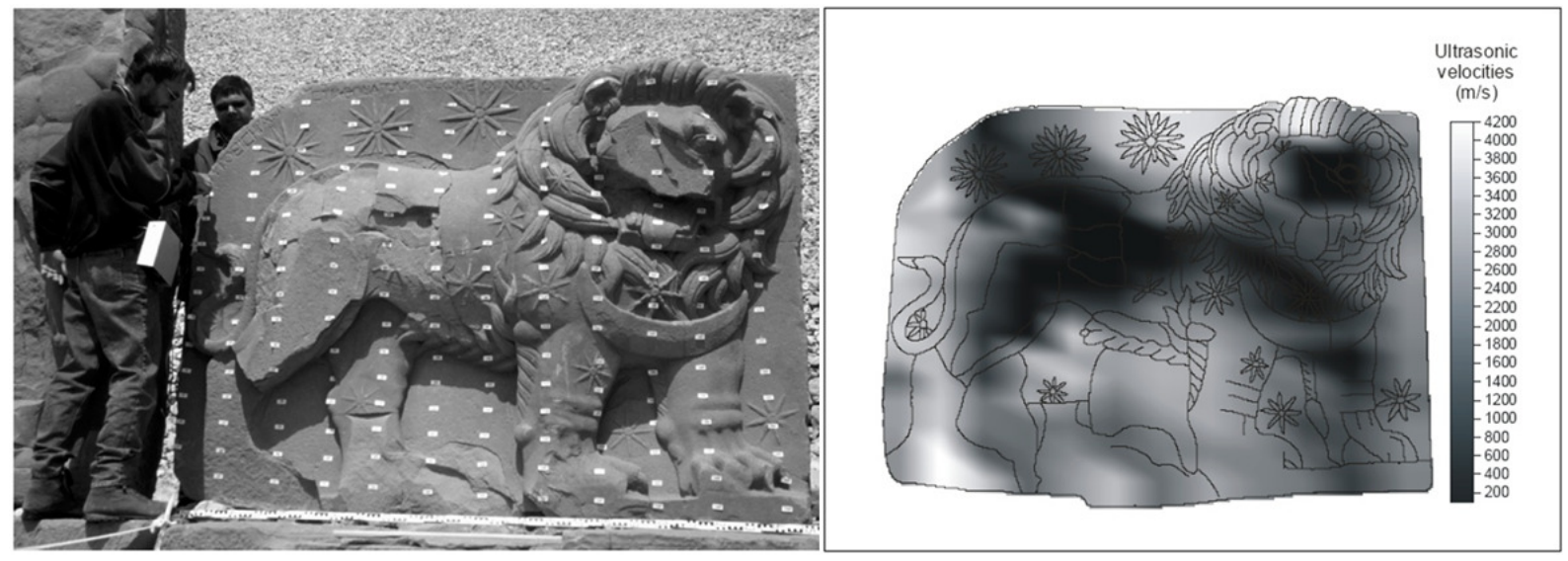

Figura 5.10 - Distribuição de pontos e execução da leitura com ultrassom em monumento [Esquerda] e diagrama das velocidades de propagação de ondas de US no monumento [Direita]. Fonte: Fitzner (2004).

Silva (2005) utiliza o método na avaliação do Teatro Municipal da cidade do Rio de Janeiro onde expressa a dificuldade de aquisição dos resultados em base constituída de rocha com superfícies irregulares, o que ocorre em função da difícil acoplagem dos transdutores à base, e comenta a influência das vibrações geradas pelo tráfego de veículos na Avenida Rio Branco, próxima ao Teatro Municipal, interferindo na avaliação pelo método de propagação de ondas ultrassônicas.

Myrin \& Malaga (2008) avaliam o tratamento de consolidação de arenito pelo método de propagação de onda ultrassônica, efetuando análises de laboratório do arenito em deterioração e na rocha recém minerada. As análises in loco ocorreram na varanda da Casa da Família Petersen, construída do século XVII, na cidade velha de Estocolmo.

Marques et al. (2010) aplicam a análise ultrassônica em rochas metamórficas utilizando o método sugerido pelo ISRM (2007). Apontam que é possível distinguir a variação da velocidade das ondas longitudinais para diferentes orientações da foliação nas rochas, bem como, a redução da velocidade de propagação de onda com o aumento da condição de intemperismo, sugerindo avaliações do método como índice de intemperismo. 


\section{Resultados e Discussões}

\subsection{Preparação da amostra para utilização em laboratório}

Dentre as amostras coletadas, uma foi preparada para os ensaios de laboratório. Esta amostra possui formato de paralelepípedo com dimensões aproximadas de 40 centímetros de comprimento, 20 centímetros de largura e 12 centímetros de altura.

O preparo da amostra consistiu na regularização da superfície de quatro faces da amostra, embora a ideia inicial fosse de que todas as faces estivessem regularizadas para os ensaios. No entanto não encontramos equipamento capaz de efetuar os cortes das faces maiores, com dimensões aproximadas de 20 por 40 centímetros, pois até mesmo as faces que foram cortadas apresentaram irregularidades, que não comprometeram as análises de laboratório (Figura 6.1).

Esta regularização fez-se necessária, pois a forma da amostra inicialmente apresentava irregularidades de relevo muito expressivas, impossibilitando a utilização do ultrassom.

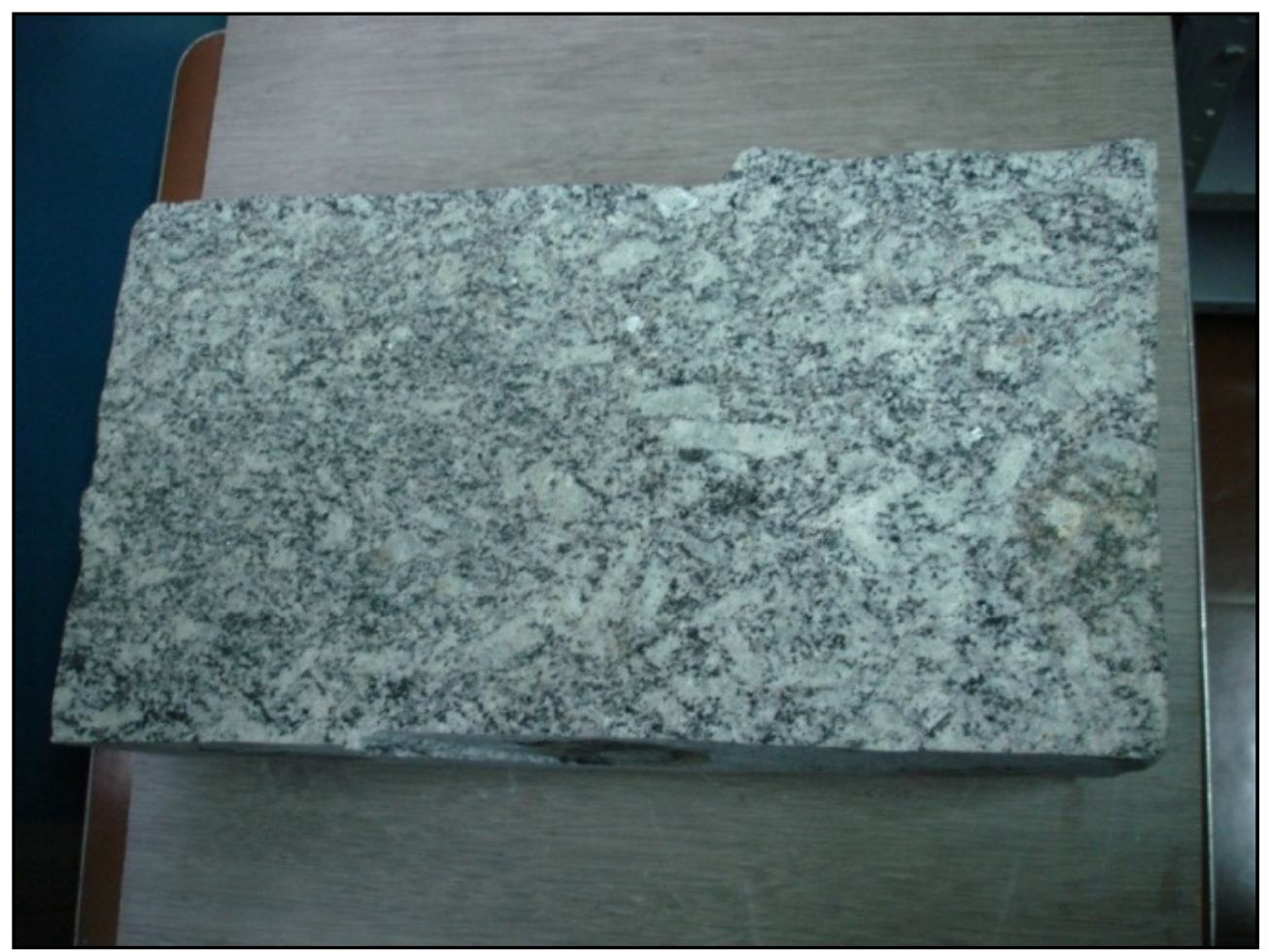

Figura 6.1 - Amostra preparada com faces serradas em quatro lados (vista superior). 


\subsection{Determinações em laboratório}

As análises de laboratório foram efetuadas seguindo as orientações das normas ASTM 2845/00 e NBR 8802/94, embora esta segunda norma refira-se unicamente a ensaios de concreto endurecido.

Considerou-se prudente que os três tipos de transmissão fossem testados a fim de efetuar os comparativos entre os resultados dos mesmos no Granito Cinza Mauá.

Esta medida também se apresentou necessária, pois não se sabia ao certo qual tipo de transmissão seria aplicável no Monumento às Bandeiras, dadas as formas, relevos e irregularidades que poderiam vir a ser encontradas no mesmo.

Assim, na amostra previamente preparada, efetuou-se a marcação e identificação de pontos para as análises nos três tipos de transmissão. Esta identificação foi efetuada da seguinte forma: as quatro faces serradas da amostra foram denominadas de Face $A$, Face $B$, Face C e Face D, sendo as faces A e B opostas assim como as faces C e D.

Navarro et al. (2003) indicam que a avaliação da propagação de onda ultrassônica deve ser realizada em diferentes pontos de acordo com o formato e tamanho da peça, sugerindo que as leituras sejam efetuadas a cada 20 centímetros segundo uma linha na secção transversal da peça (Figura 6.2).

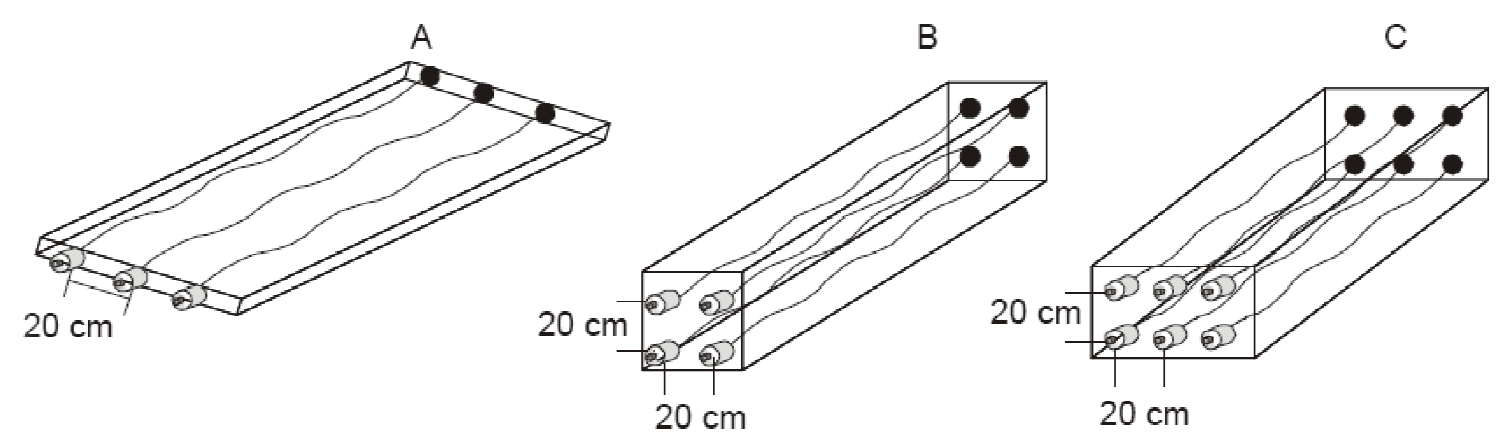

(2) Transdutor de emissão - Transdutor de recepção m onda de ultra-som

Figura 6.2 - Esquema hipotético para medidas de ultrassom em diferentes tipos de blocos de rocha. Fonte: Navarro et al. (2003).

De acordo com as dimensões da amostra, adequaram-se um ponto de leitura para as faces $A$ e $B$ e três pontos de leitura para as faces $C$ e $D$ com espaçamentos de centro a centro de aproximadamente 15 centímetros entre os pontos de uma mesma face, estes pontos foram dispostos nas extremidades de quatro eixos que cortam a amostra de lado a lado, sendo que o Eixo 1 liga os pontos posicionados nas faces $A$ e $B$, e os Eixos 2, 3 e 4 
ligam os pontos a estes correspondentes nas faces $C$ e $D$. Dessa forma os pontos foram denominados de acordo com o encontro entre as faces e os eixos, totalizando oito pontos, sendo estes definidos como pontos: 1A, 1B, 2C, 3C, 4C, 2D, 3D e 4D. A exemplificação das disposições das faces, eixos e pontos na amostra está exibida na Figura 6.3.

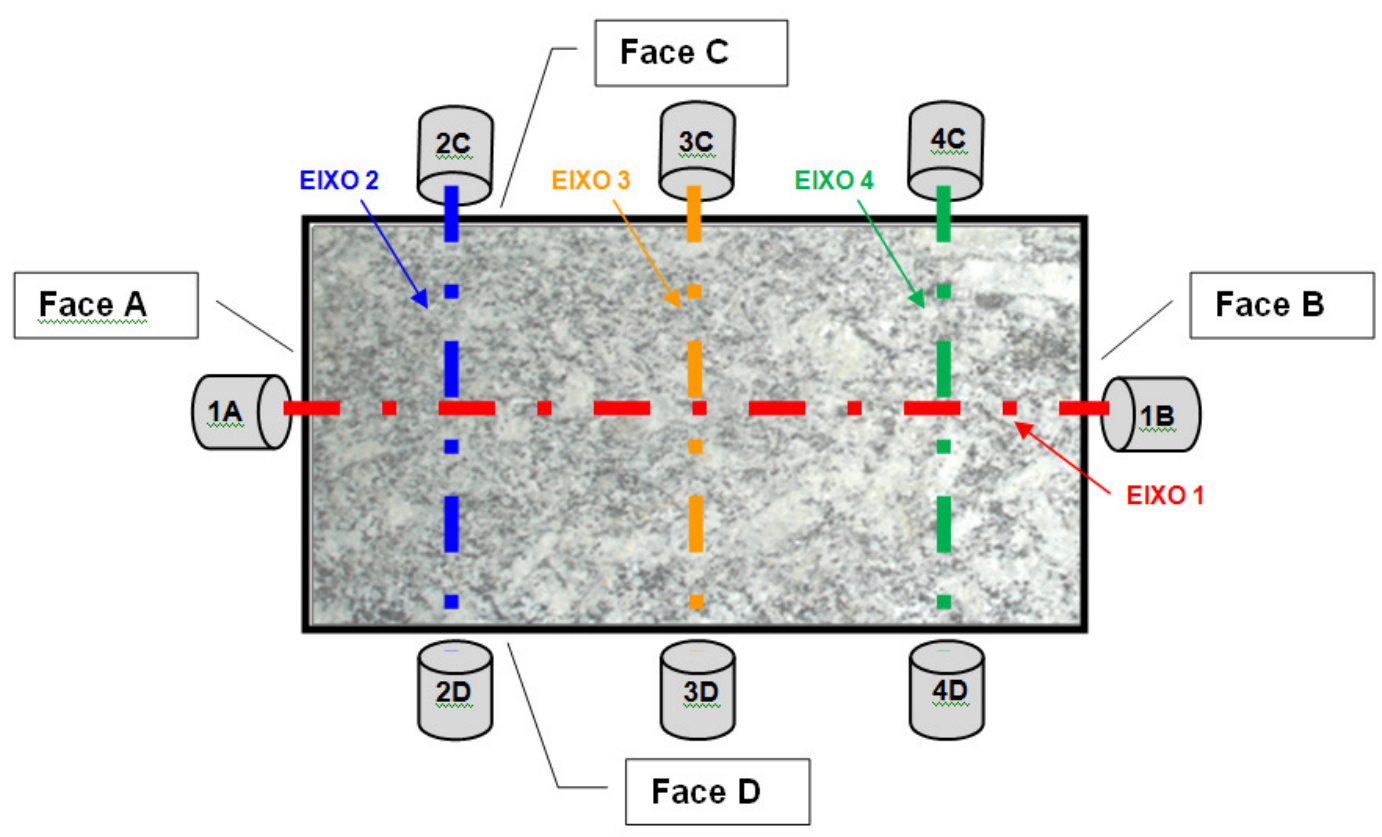

Figura 6.3 - Esquema da disposição dos pontos de leitura em relação aos eixos e faces de referência.

$\mathrm{Na}$ sequência, determinou-se que as leituras seriam efetuadas na amostra nos três tipos de transmissão, diferindo-se os pares de transdutores em todas as análises, pois estes também seriam empregados nos estudos do Monumento às Bandeiras.

Foram utilizados os pares de transdutores exponenciais e os transdutores planos de $54 \mathrm{kHz}$ e de $150 \mathrm{kHz}$.

As distâncias entre os pontos de leitura nas avaliações da amostra de laboratório foram medidas com o auxílio de paquímetro, obtendo-se as dimensões de centro a centro dos pontos para os três tipos de transmissão efetuados na amostra, todos com precisão de $0,1 \mathrm{~mm}$.

A aplicação dos métodos de transmissão direta, semidireta e indireta está esquematizada nas Figuras 6.4 a 6.6, respectivamente. 


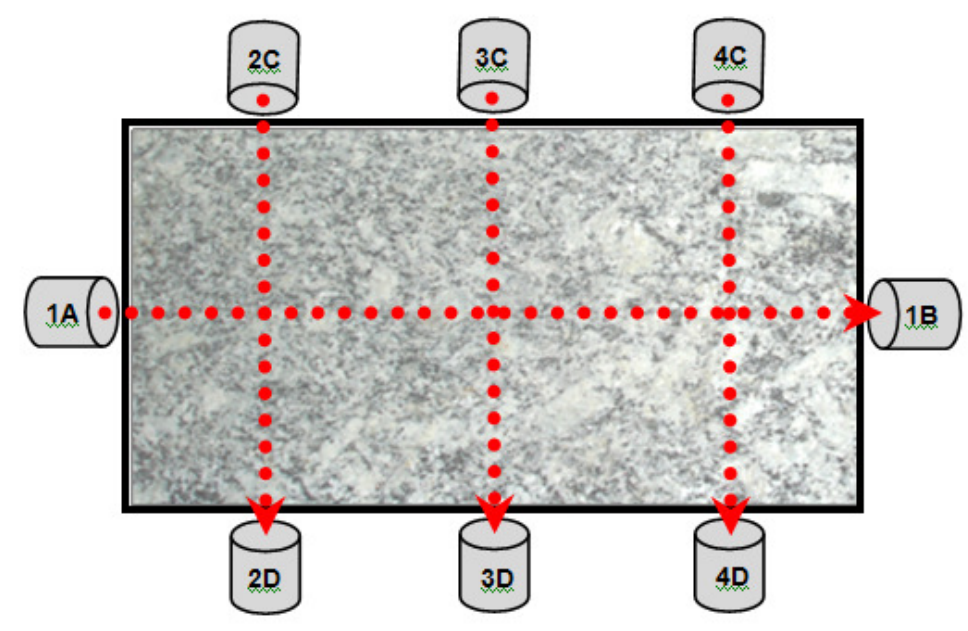

Figura 6.4 - Diagrama da aplicação das leituras da transmissão direta na amostra de laboratório.

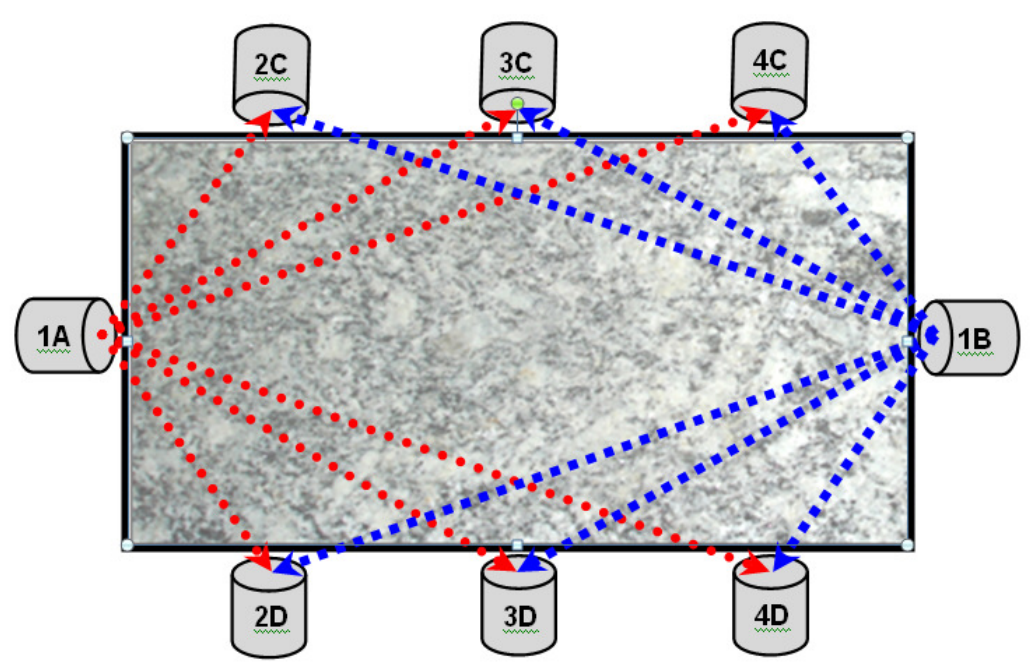

Figura 6.5 - Diagrama da aplicação das leituras da transmissão semidireta na amostra de laboratório.

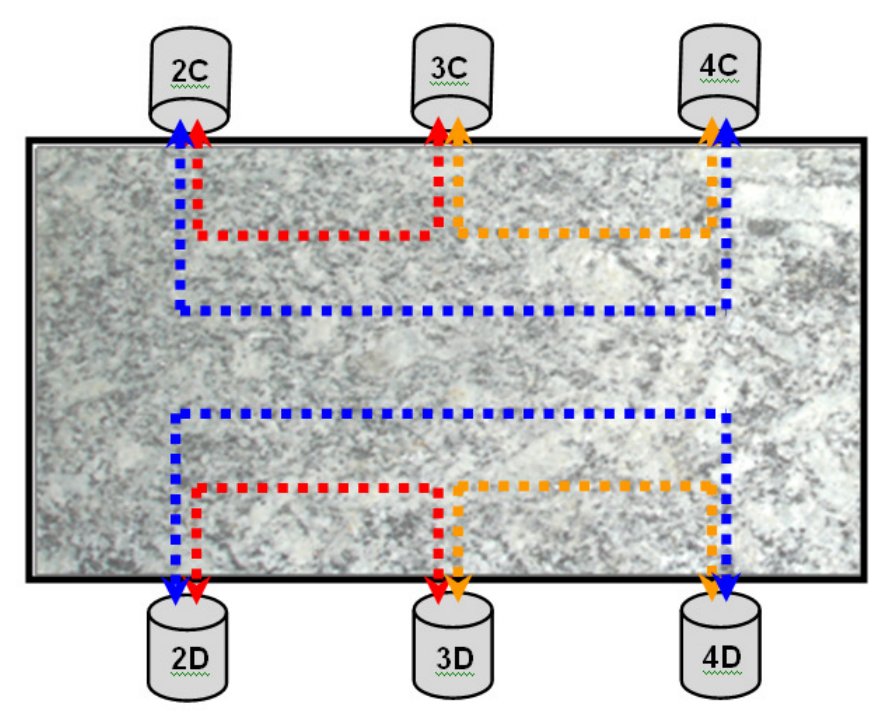

Figura 6.6 - Diagrama da aplicação das leituras da transmissão indireta na amostra de laboratório. 


\subsection{Determinações nas figuras do monumento}

O Monumento às Bandeiras é uma obra com formas volumétricas de grandes dimensões, as figuras que o compõe representam corpos humanos, cavalos e uma canoa, bem como alguns objetos que são representados juntamente as figuras. Esta característica das formas que se aproximam à anatomia de corpos humanos restringe muito o paralelismo perfeito de faces para a determinação de pontos de leitura, uma vez que os métodos sugeridos pelas normas NBR 8802/94 e ASTM D 2845/00 tratam a necessidade da presença dessas faces para a realização dos ensaios. Outro fator notório e prejudicial para a determinação dos pontos de leitura efetuados no monumento é a variação de acabamento superficial presente no monumento, pois quanto maior a rugosidade, pior torna-se a acoplagem dos transdutores no mesmo. Os braços, pernas e objetos representados no monumento apresentam rugosidades satisfatórias, já os cavalos, cabeças, torsos e a canoa, apresentam rugosidade elevada, e em muitos pontos, a exemplo da canoa, a superfície é de acabamento apicoado, ou seja, muito irregular.

Portanto definiu-se que as leituras nas figuras do monumento seriam efetuadas em todo o entorno do monumento nas figuras que apresentassem superfícies com rugosidade baixa, passível da acoplagem dos transdutores.

As dimensões foram levantadas com auxílio de paquímetro, onde os pontos de leitura permitiam determinar a distância do ponto de emissão até o ponto de recepção da onda. Os bicos do paquímetro, em alguns casos, não alcançaram os pontos de faces posteriores do monumento, para estes casos extraímos a medida com o auxílio do compasso externo, que permite fixar a abertura do mesmo entre os pontos com maior facilidade, e posteriormente retira-se o compasso com a dimensão fixada e então é determinada com auxílio de paquímetro ou trena.

Como somente o paquímetro nos permite a determinação da distância com precisão igual ou superior a $0,1 \mathrm{~mm}$, determinamos que a precisão para os pontos lidos com o auxílio do compasso externo apresentariam precisão de $1 \mathrm{~mm}$.

A transmissão direta foi a única utilizada para as avaliações das figuras do monumento, executadas em pontos opostos de uma secção transversal, de forma que os transdutores emissor e receptor estivessem frontalmente posicionados (Figura 6.7).

As avaliações pela transmissão semidireta não foram realizadas, pois requerem que os transdutores sejam posicionados em planos perpendiculares o que era impossível de se assegurar em função das formas arredondadas do monumento.

A transmissão indireta não foi utilizada nas figuras que constituem o monumento por estas não apresentarem planos contínuos com rugosidade satisfatória onde este tipo de transmissão pudesse ser empregado. 
Os três pares de transdutores foram utilizados na avaliação do Monumento às Bandeiras No entanto, os transdutores exponenciais não apresentaram resultados satisfatórios nos primeiros testes efetuados no monumento, pois o sinal emitido por muitas vezes não era recebido, outro fator que dificultou as análises com estes é que o tempo apresentado pelo aparelho, mesmo em um mesmo ponto, raramente se repetia, tornando assim este par de transdutores inadequado para a avaliação proposta neste estudo.

Os estudos prosseguiram somente com a utilização dos pares de transdutores planos de $54 \mathrm{kHz}$ e $150 \mathrm{kHz}$, estes apresentaram comportamento adequado nas leituras, diferindo suas condições de acoplagem em função das superfícies de contato e área da base.

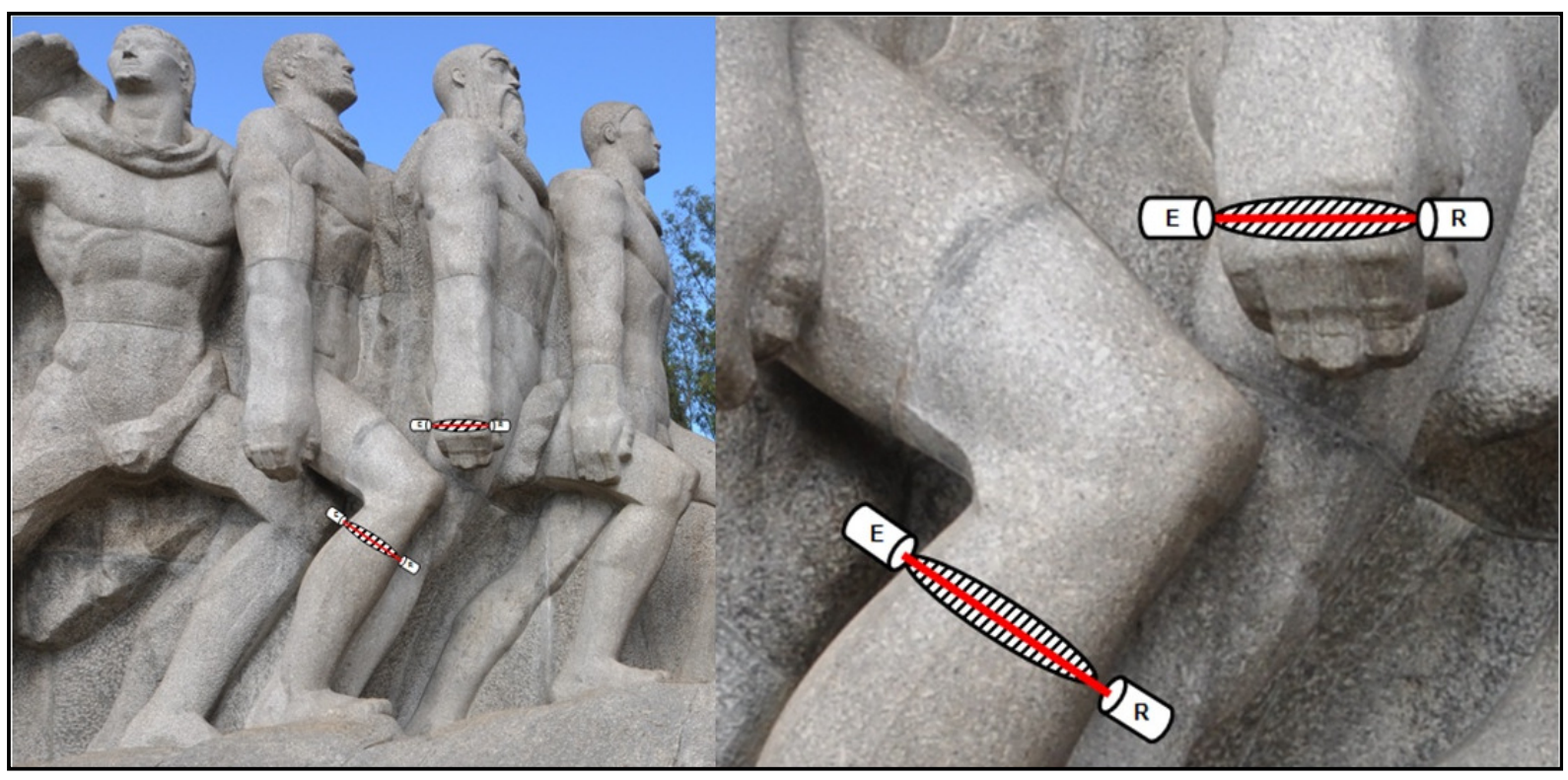

Figura 6.7 - Esquema ilustrativo da aplicação do método ultrassônico pela transmissão direta. Imagem das figuras e pontos de leitura no Monumento às Bandeira apresentando os transdutores, emissor (E) e receptor $(R)$ [Esquerda]. Detalhe dos pontos de leitura, posicionamento dos transdutores e percurso da onda [Direita]. Foto: Lauro K. Dehira - 26.05.2012.

\subsubsection{Determinações na base do monumento}

A base do Monumento às Bandeiras apresenta o Granito Cinza Mauá com acabamento rústico, praticamente em estado bruto, exceto em função de áreas planas e polidas, que se tratam de quatro placas onde estão representados, o mapa das bandeiras, na face frontal e demais inscrições nas outras três faces do monumento. 
Os trabalhos de ultrassom nesta área foram efetuados em apenas uma das áreas polidas da rocha do monumento, através do método indireto. Foram utilizados nestas avaliações os transdutores planos de 54 kHz e 150 kHz (Figura 6.8).

Para esta região, as transmissões direta e semidireta foram descartadas por não existirem meios de se posicionar os transdutores em faces paralelas ou perpendiculares.

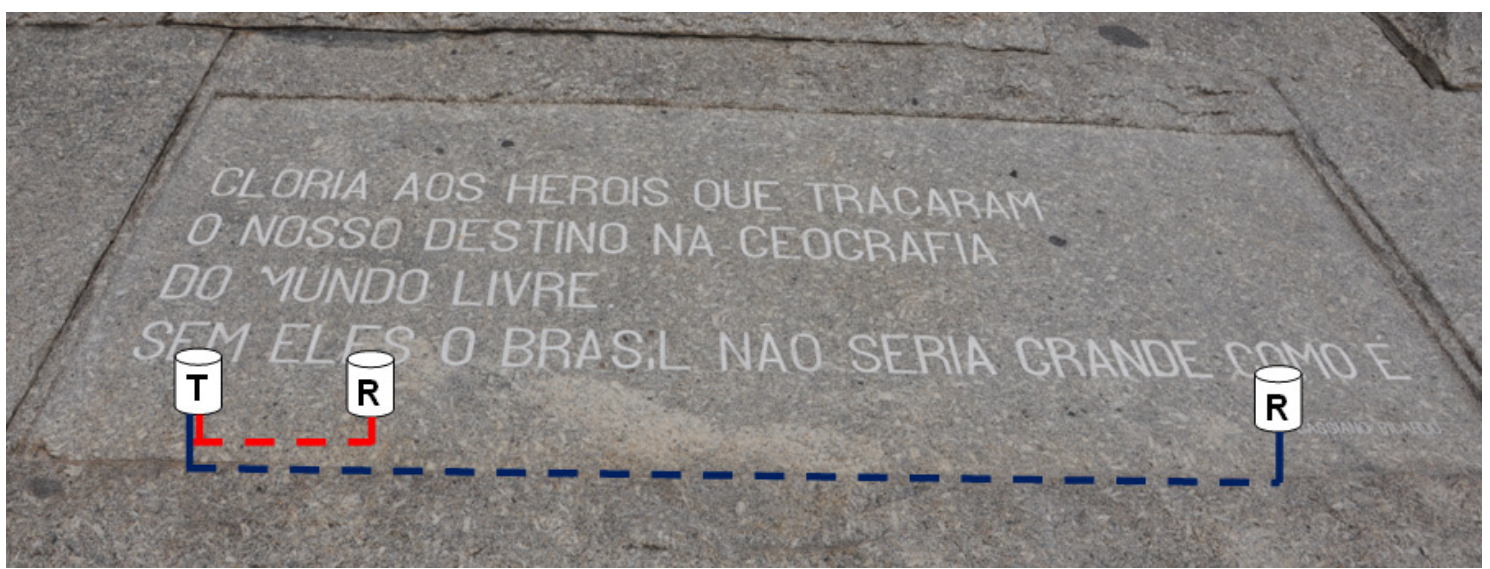

Figura 6.8 - Exemplificação da aplicação da transmissão indireta na base do Monumento às Bandeiras.

\subsection{Condições Gerais de Avaliação Ultrassônica no Monumento às Bandeiras e em Amostra de Laboratório}

Para todas as leituras efetuadas no Monumento às Bandeiras, da mesma forma que no laboratório, fez-se uso de acoplante em gel, sendo que a quantidade de acoplante utilizado para cada situação foi condicionada à rugosidade da superfície de análise de cada ponto.

No monumento, após a execução das leituras realizadas, procedeu-se a limpeza para remoção do acoplante, esta foi efetuada com água e escova de nylon com cerdas macias e inspecionada para a certificação de que todos os resíduos do acoplante haviam sido eliminados da superfície do monumento.

O critério de definição da leitura do valor do tempo de percurso da onda através do corpo ensaiado consiste na estabilidade/repetibilidade do valor apresentado pelo aparelho em três ou mais emissões do pulso ultrassônico, ou seja, para cada leitura executada neste trabalho, o resultado apresentado pelo aparelho teve de repetir-se no mínimo três vezes consecutivas para ser considerado válido.

É importante acrescentar que este critério de estabilidade de leitura mostrou-se ineficiente na utilização do par de transdutores exponenciais em função da alta variação dos 40 
resultados para um mesmo ponto, ocorrência esta que se manteve tanto nas leituras de laboratório quanto nas leituras efetuadas no monumento.

\subsection{Avaliações em Laboratório}

De acordo com os objetivos do trabalho, as análises de laboratório foram executadas na amostra previamente citada como objeto comparativo aos trabalhos efetuados no Monumento às Bandeiras.

Os ensaios realizados resultaram na determinação do valor médio da velocidade de propagação de ondas ultrassônicas no Granito Cinza Mauá, constituinte da amostra de laboratório, utilizando-se as transmissões direta, semidireta e indireta.

As avaliações comparativas em laboratório foram importantes não somente para a determinação da diferença física entre a amostra sã e o Monumento às Bandeiras, mas também para a adequação do método ao estudo do monumento.

Nos tópicos a seguir estão expostas as representações gráficas dos resultados, bem como as tabelas dos resultados médios da velocidade de propagação de ondas ultrassônicas para cada tipo de transmissão, complementados pelo desvio padrão, o afastamento relativo e o desvio relativo máximo.

\subsubsection{Transmissão Direta}

$\mathrm{Na}$ Figura 6.9 estão dispostos os resultados da determinação da velocidade de propagação de ondas ultrassônicas pelo método direto e do comparativo entre os transdutores de $54 \mathrm{kHz}, 150 \mathrm{kHz}$ e exponenciais da amostra submetida aos ensaios de laboratório. Buscou-se verificar a confiabilidade e estabilidade de cada par de transdutores, comparando-se entre os três tipos qual se apresenta mais eficaz para utilização em campo. 


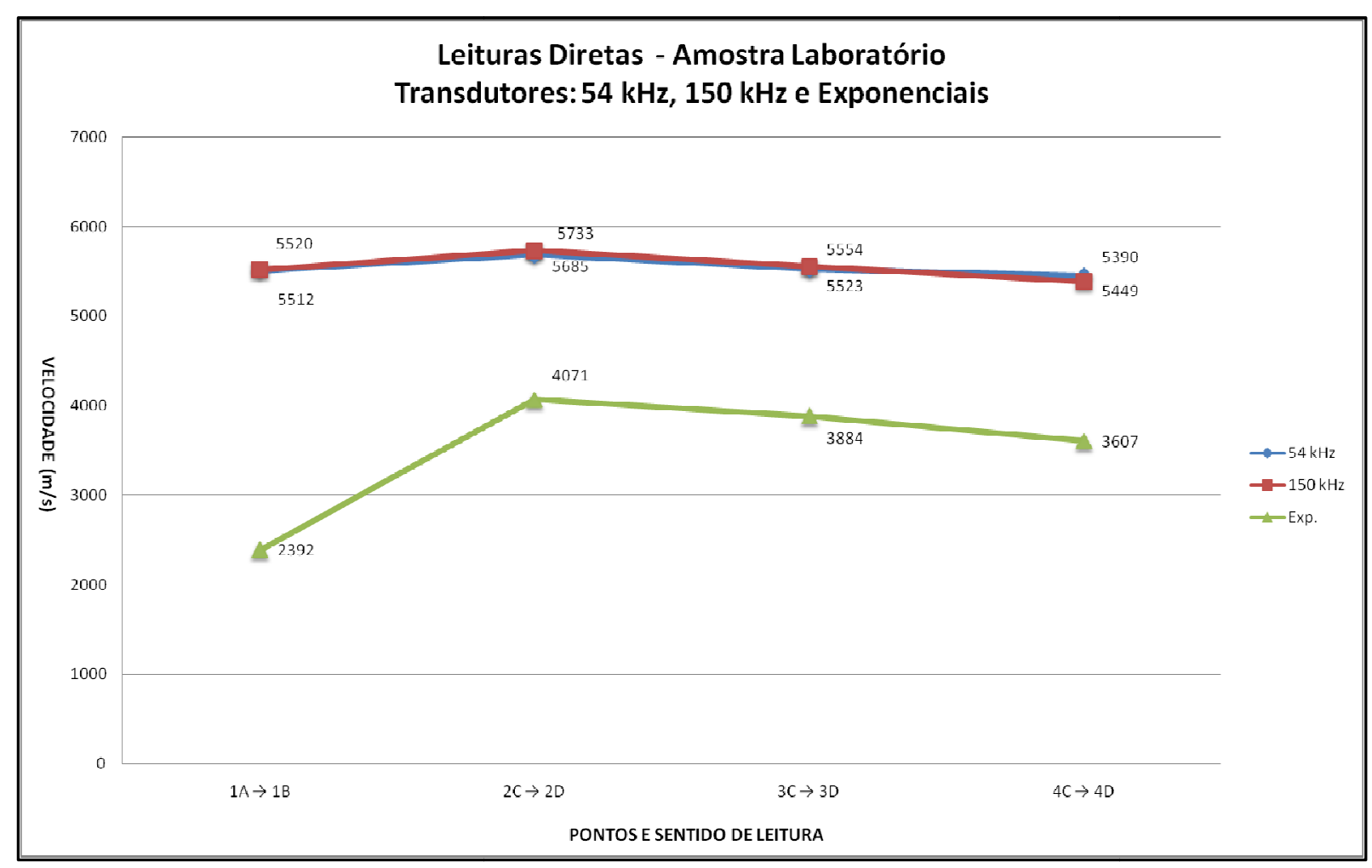

Figura 6.9 - Transmissão direta em amostra de laboratório.

Analisando o gráfico da Figura 6.9 é possível verificar que os pares de transdutores de $54 \mathrm{kHz}$ e de $150 \mathrm{kHz}$ apresentaram resultados similares, sendo que os transdutores exponenciais geraram resultados mais discrepantes.

Os resultados do desvio padrão e desvio relativo máximo com os transdutores de 54 $\mathrm{kHz}$ e de $150 \mathrm{kHz}$ também apresentaram maior estabilidade entre as leituras, sendo o desvio padrão dos transdutores exponenciais cerca de cinco a sete vezes maior, e desvio relativo máximo, dez vezes maior comparando-se aos outros transdutores (Tabela 6.1).

Tabela 6.1 - Resultados médios e desvios na análise da transmissão direta em laboratório.

\begin{tabular}{ccccc}
\hline Transdutores & $\begin{array}{c}\text { Velocidade Média } \\
(\mathbf{m} / \mathbf{s})\end{array}$ & $\begin{array}{c}\text { Desvio } \\
\text { Padrão }(\mathbf{m} / \mathbf{s})\end{array}$ & $\begin{array}{c}\text { Afastamento } \\
\text { Relativo }(\mathbf{m} / \mathbf{s})\end{array}$ & $\begin{array}{c}\text { Desvio Relativo } \\
\text { Máximo }(\%)\end{array}$ \\
\hline $\mathbf{5 4} \mathbf{~ k H z}$ & 5.542 & 101 & 143 & 2,6 \\
$\mathbf{1 5 0} \mathbf{~ k H z}$ & 5.549 & 142 & 184 & 3,3 \\
Exponenciais & 3.488 & 756 & 1096 & 31,4 \\
\hline
\end{tabular}




\subsubsection{Transmissão Semidireta}

Analisando a Figura 6.10, vemos que existe uma tendência entre os transdutores de $54 \mathrm{kHz}$ e $150 \mathrm{kHz}$ em apresentar velocidades entre 5.000 e $6.000 \mathrm{~m} / \mathrm{s}$, o que confirma a maior confiabilidade para estes transdutores, enquanto os transdutores exponenciais não apresentam homegeneidade de resultados. Notemos também que mesmo com a alteração da transmissão de direta para semidireta os resultados das velocidades apresentaram-se dentro do mesmo intervalo ocorrido na transmissão direta, isso avaliando os transdutores planos sem considerar os transdutores exponenciais. A diferença mais visível para estes transdutores foi o aumento do desvio padrão e desvio relativo máximo (Tabela 6.2), ou seja, esse tipo de transmissão gera maior dificuldade ao operador, por ser mais penoso em se obter repetibilidade das leituras.

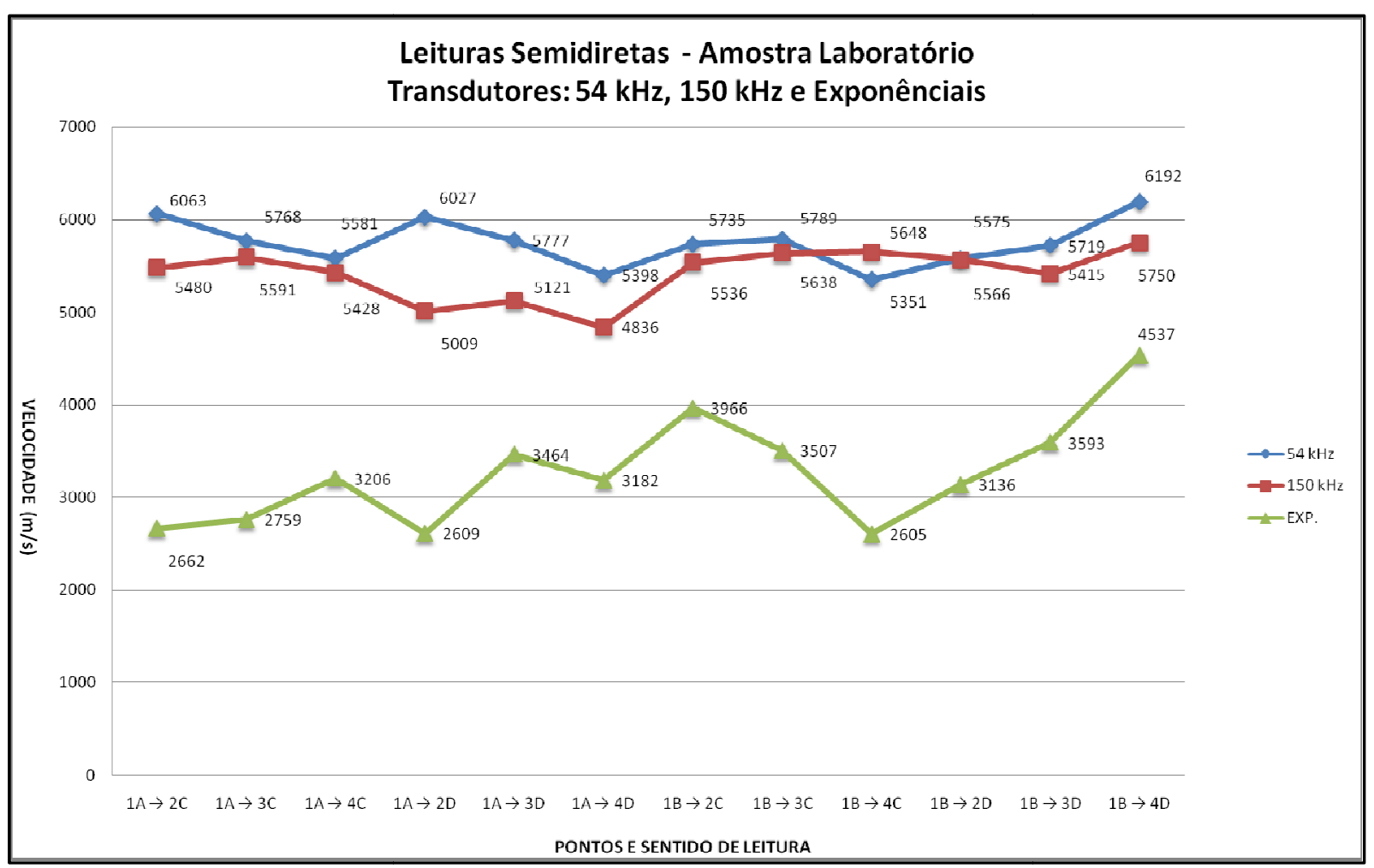

Figura 6.10 - Transmissão semidireta em amostra de laboratório.

Tabela 6.2 - Resultados médios e desvios na análise da transmissão semidireta em laboratório.

\begin{tabular}{ccccc}
\hline Transdutores & $\begin{array}{c}\text { Velocidade } \\
\text { Média (m/s) }\end{array}$ & $\begin{array}{c}\text { Desvio Padrão } \\
(\mathbf{m} / \mathbf{s})\end{array}$ & $\begin{array}{c}\text { Afastamento } \\
\text { Relativo (m/s) }\end{array}$ & $\begin{array}{c}\text { Desvio Relativo } \\
\text { Máximo (\%) }\end{array}$ \\
\hline $\mathbf{5 4} \mathbf{~ k H z}$ & 5.748 & 255 & 444 & 7,7 \\
$\mathbf{1 5 0} \mathbf{~ k H z}$ & 5.418 & 282 & 583 & 10,8 \\
\hline Exponenciais & 3.269 & 590 & 1268 & 38,8 \\
\hline
\end{tabular}


As avaliações pela transmissão semidireta, igualmente às realizadas pela transmissão direta, confirmam uma estabilidade maior nas leituras realizadas com os transdutores de $54 \mathrm{kHz}$ e $150 \mathrm{kHz}$ apresentando velocidades consideravelmente próximas, desvio padrão, desvio médio e afastamento relativo inferiores ao ocorrido com os transdutores exponenciais.

\subsubsection{Transmissão Indireta}

O principal aspecto mostrado na Figura 6.11 é o fato dos transdutores exponenciais, mesmo apresentando valores muito discrepantes, apresentam maior estabilidade nos resultados se comparados com os obtidos pela transmissão direta e semidireta com este par de transdutores. O fator desta melhor concordância de resultados na transmissão indireta utilizando os transdutores exponenciais pode ocorrer pelo fato da onda ultrassônica não penetrar consideravelmente na rocha, sendo seu percurso predominantemente superficial, fator este que contribui com a estabilidade nas leituras efetuadas.

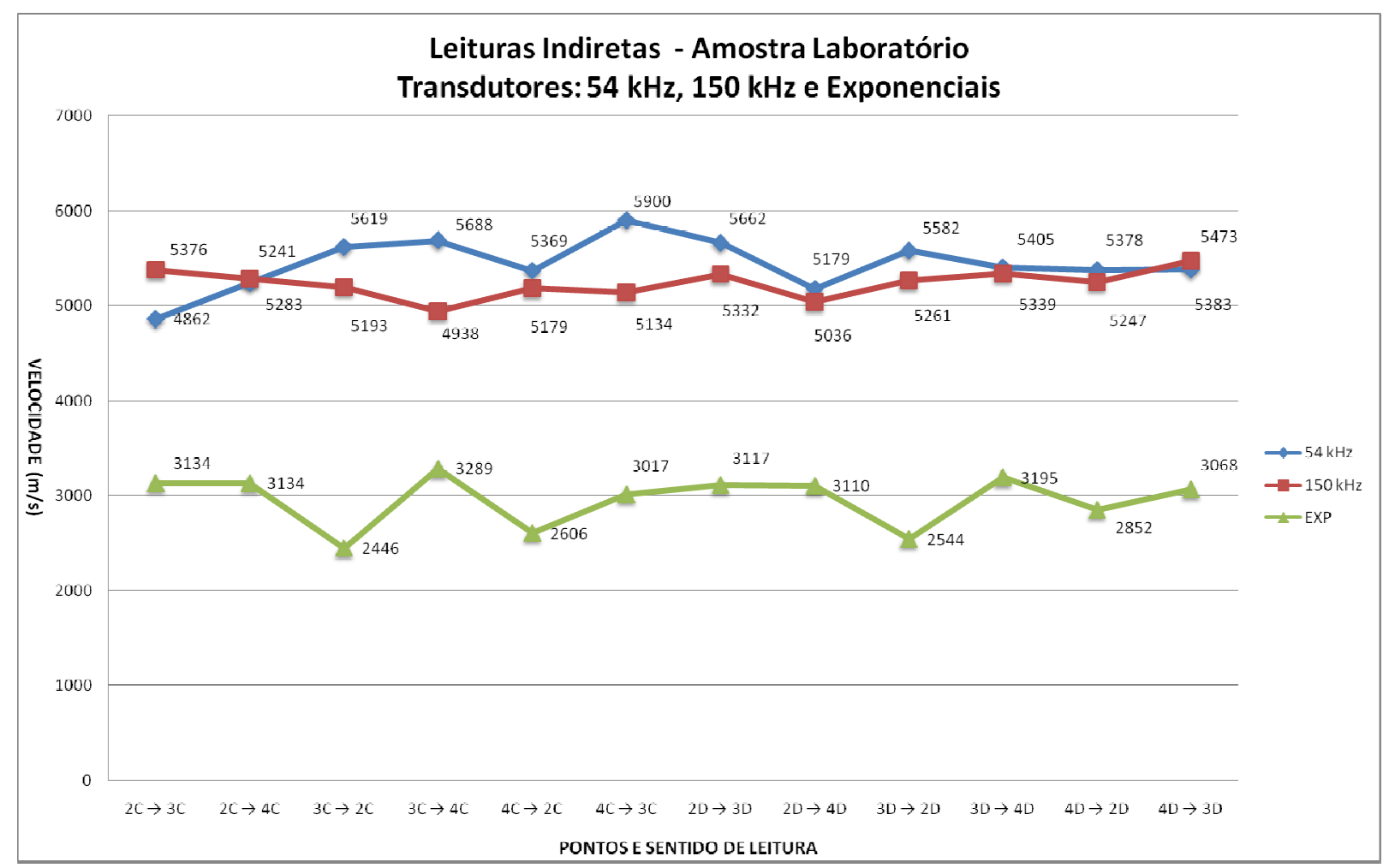

Figura 6.11 - Transmissão indireta em amostra de laboratório. 
Neste tipo de transmissão, considerada a menos favorável para execução de análises, ocorreu uma grande dispersão dos valores das velocidades, embora estes apresentem um intervalo coerente para cada tipo de transdutor.

No entanto, vemos que o transdutor de $54 \mathrm{kHz}$ apresenta os valores médios mais próximos dos resultados obtidos nas transmissões direta e semidireta, mas o desvio relativo máximo se eleva, o que já não ocorre com o transdutor de $150 \mathrm{kHz}$ que apresenta redução neste quesito (Tabela 6.3).

Tabela 6.3 - Resultados médios e desvios na análise da transmissão indireta em laboratório.

\begin{tabular}{ccccc}
\hline Transdutores & $\begin{array}{c}\text { Velocidade } \\
\text { Média (m/s) }\end{array}$ & $\begin{array}{c}\text { Desvio Padrão } \\
(\mathbf{m} / \mathbf{s})\end{array}$ & $\begin{array}{c}\text { Afastamento Relativo } \\
(\mathbf{m} / \mathbf{s})\end{array}$ & $\begin{array}{c}\text { Desvio Relativo } \\
\text { Máximo }(\%)\end{array}$ \\
\hline $\mathbf{5 4} \mathbf{~ k H z}$ & 5.439 & 275 & 577 & 10,6 \\
$\mathbf{1 5 0} \mathbf{~ k H z}$ & 5.233 & 149 & 295 & 5,6 \\
Exponenciais & 2.959 & 280 & 513 & 17,3 \\
\hline
\end{tabular}

\subsection{Comparativos de leituras entre diversos operadores}

Os primeiros ensaios realizados em laboratório demonstraram que ocorreu variação em relação às médias nos resultados utilizando-se os três tipos de transmissão, estes ocorreram na ordem de 2 a 11\% para os transdutores de $54 \mathrm{kHz}$ e $150 \mathrm{kHz}$ e 17 a $38 \%$ para os transdutores exponenciais.

A variação nos resultados de laboratório levantou a preocupação para a operação do aparelho de ultrassom, necessitávamos saber se havia influência do operador ou se esta característica estava intrínseca à amostra analisada.

Para isso, resolveu-se efetuar o comparativo entre as leituras de quatro operadores na mesma amostra, com isso buscava-se determinar se as leituras efetuadas nos mesmos pontos e com mesmas distâncias apresentariam resultados idênticos ou aproximados.

Certamente a ocorrência de leitura extremamente discrepante aos valores médios pode ser detectada como erro ou falha de leitura, assim podendo se descartar a mesma do resultado médio global.

Para determinar a discrepância de análise entre os operadores utilizamos as avaliações dos resultados do desvio padrão, afastamento relativo e desvio relativo máximo.

Outra contribuição que o comparativo entre operadores pode nos fornecer é o aspecto da repetibilidade operacional, ou seja, nos informará se qualquer usuário submetido a um treinamento básico de operação é capaz de utilizar o equipamento de ultrassom, e se os diversos operadores são capazes de obter resultados dentro de uma faixa aceitável de variação em uma mesma amostra. 
Neste estudo utilizou-se um único aparelho de ultrassom, assim sugere-se que estudos comparativos com diferentes operadores e aparelhos distintos de diferentes fabricantes sejam efetuados para maior aprimoramento da utilização do método.

$\mathrm{Na}$ Tabela 6.4, constam os resultados obtidos no comparativo entre diversos operadores pela transmissão direta.

Tabela 6.4 - Resultados médios e desvios na análise da transmissão direta no comparativo de diversos operadores.

\begin{tabular}{|c|c|c|c|c|c|}
\hline \multirow{3}{*}{ Transdutores } & Operador & $\begin{array}{c}\text { Velocidade } \\
\text { Média }(\mathbf{m} / \mathbf{s})\end{array}$ & $\begin{array}{c}\text { Desvio } \\
\text { Padrão } \\
(\mathbf{m} / \mathbf{s})\end{array}$ & $\begin{array}{c}\text { Afastamento Relativo } \\
(\mathbf{m} / \mathbf{s})\end{array}$ & $\begin{array}{c}\text { Desvio Relativo } \\
\text { Máximo (\%) }\end{array}$ \\
\hline \multirow{3}{*}{$\mathbf{5 4} \mathbf{~ k H z}$} & 1 & 5.542 & 101 & 143 & 2,6 \\
\cline { 2 - 6 } & 2 & 5.326 & 134 & 156 & 2,9 \\
\cline { 2 - 6 } & 3 & 5.237 & 106 & 107 & 2,0 \\
\hline \multirow{3}{*}{$\mathbf{1 5 0} \mathbf{k H z}$} & 4 & 5.279 & 61 & 78 & 1,5 \\
\cline { 2 - 6 } & 1 & 5.549 & 142 & 184 & 3,3 \\
\cline { 2 - 6 } & 2 & 5.532 & 47 & 60 & 1,1 \\
\hline \multirow{5}{*}{ Exponenciais } & 3 & 5.391 & 36 & 54 & 1,0 \\
\cline { 2 - 6 } & 4 & 5.391 & 46 & 54 & 1,0 \\
\cline { 2 - 6 } & 2 & 3.488 & 756 & 1097 & 31,4 \\
\cline { 2 - 6 } & 3 & 3.338 & 584 & 875 & 26,2 \\
\hline
\end{tabular}

Embora sejam visíveis as variações nos resultados globais das médias, na maioria o comparativo gerou desvios inferiores aos realizados anteriormente, apresentados nesta tabela com os valores do operador 1 .

Através do desvio relativo máximo obtido pelos quatro operadores pode-se concluir que é possível que diferentes operadores utilizando um mesmo aparelho e amostra de estudo sejam capazes de atingir valores muito próximos, sendo a variação entre os resultados deste tipo de transmissão na ordem de $6 \%$, considerando-se o valor médio da velocidade entre os operadores.

Os gráficos representados nas Figuras 6.12 a 6.14 demonstram o comportamento dos resultados para cada operador, utilizando os transdutores de $54 \mathrm{kHz}, 150 \mathrm{kHz} \mathrm{e}$ exponenciais. Os transdutores de $54 \mathrm{kHz}$ e $150 \mathrm{kHz}$ apresentaram resultados aproximados, o que não ocorre na utilização dos transdutores exponenciais, ficando clara a alta dispersão de resultados na utilização destes. 


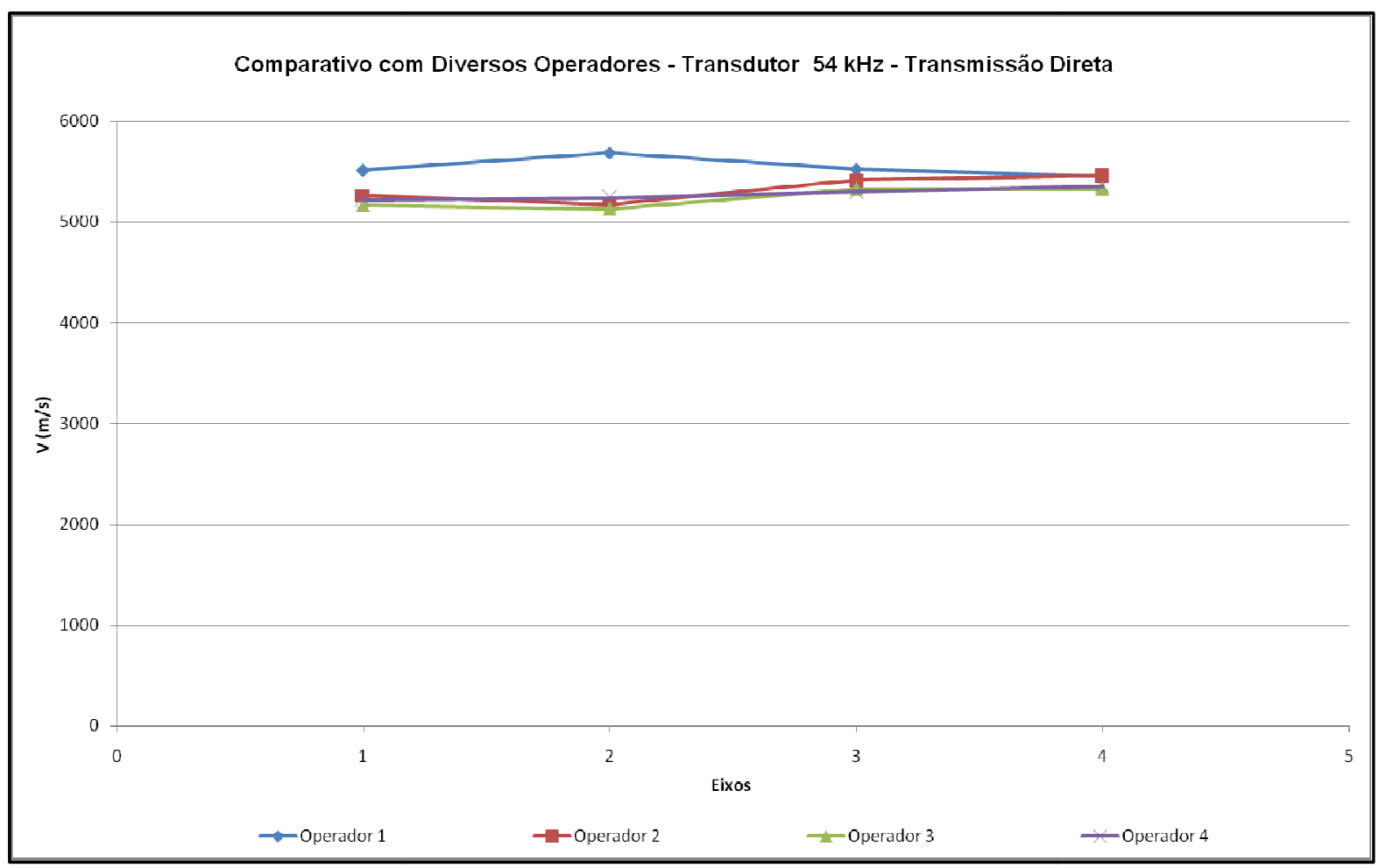

Figura 6.12 - Transmissão Direta - Transdutores de 54 kHz - Comparativo com diversos operadores.

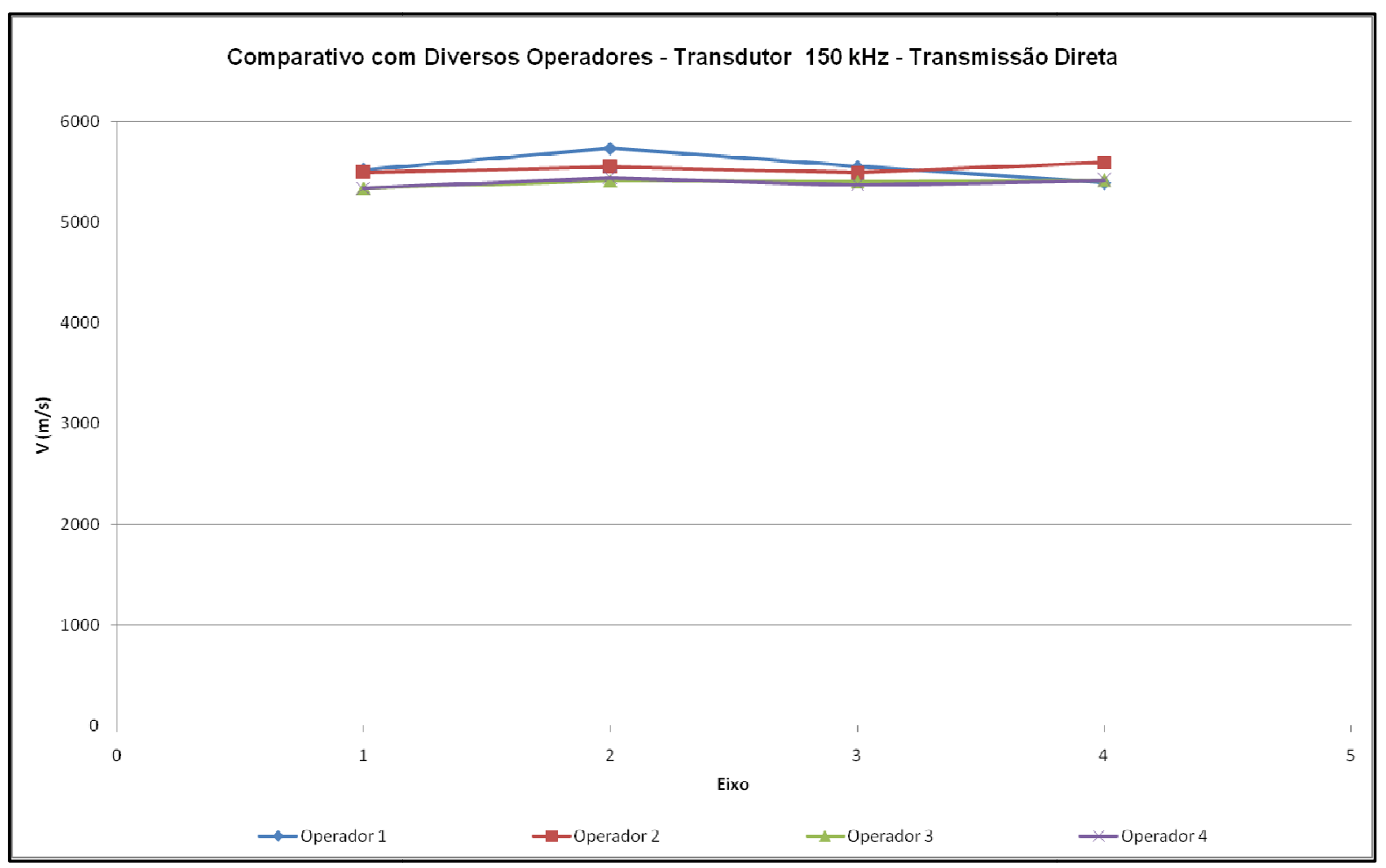

Figura 6.13 - Transmissão Direta - Transdutores de 150 kHz - Comparativo com diversos operadores. 


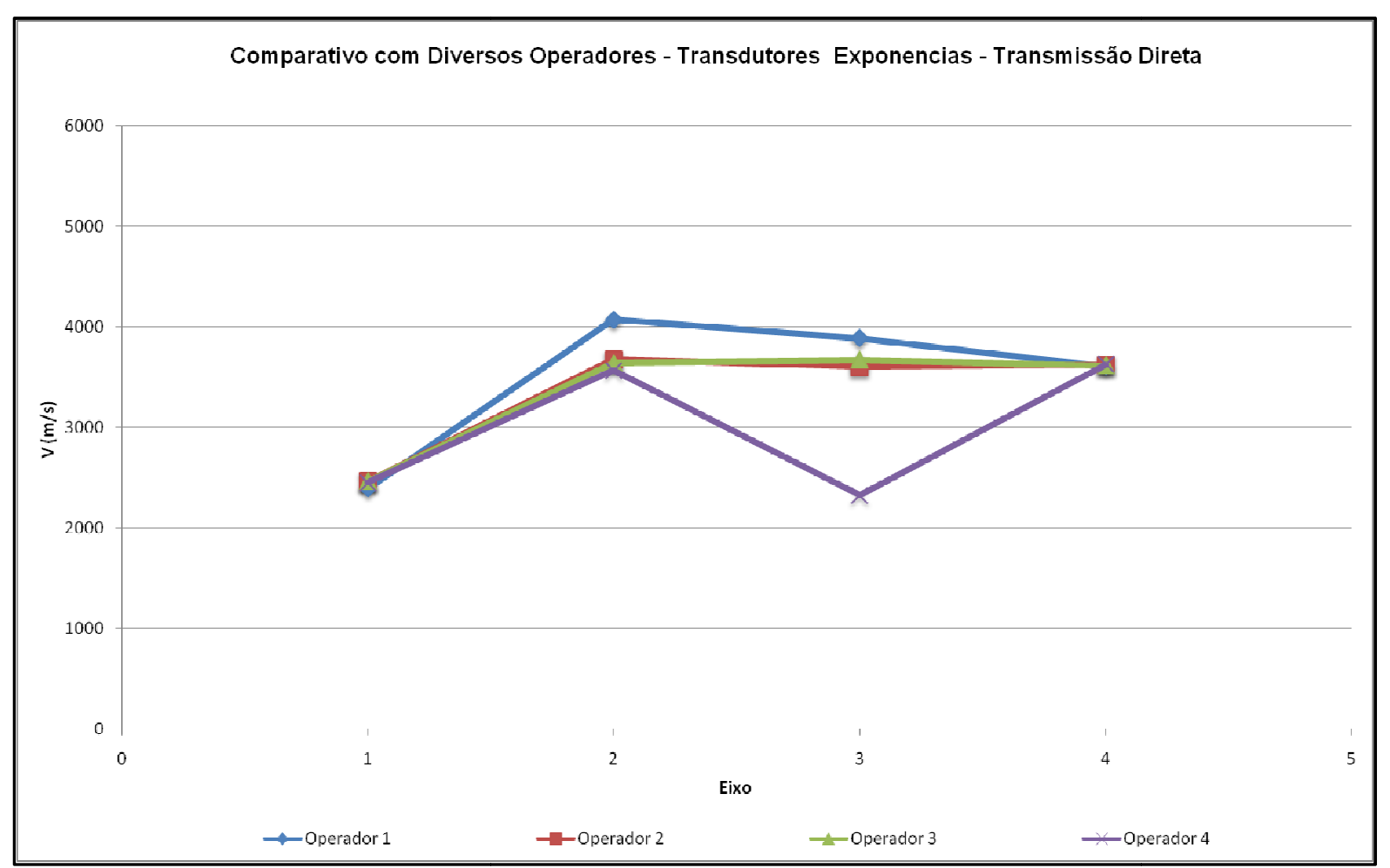

Figura 6.14 - Transmissão Direta - Transdutores Exponenciais - Comparativo com diversos operadores.

$\mathrm{Na}$ Tabela 6.5, seguem os resultados obtidos através dos estudos realizados no comparativo entre diversos operadores pela transmissão semidireta.

Tabela 6.5 - Resultados médios e desvios na análise da transmissão semidireta no comparativo de diversos operadores.

\begin{tabular}{|c|c|c|c|c|c|}
\hline Transdutores & Operador & $\begin{array}{l}\text { Velocidade } \\
\text { Média }(\mathrm{m} / \mathrm{s})\end{array}$ & $\begin{array}{c}\text { Desvio } \\
\text { Padrão } \\
\text { (m/s) }\end{array}$ & $\begin{array}{l}\text { Afastamento } \\
\text { Relativo }(\mathrm{m} / \mathrm{s})\end{array}$ & $\begin{array}{c}\text { Desvio Relativo } \\
\text { Máximo (\%) }\end{array}$ \\
\hline \multirow{4}{*}{$54 \mathrm{kHz}$} & 1 & 5.748 & 255 & 1068 & 18,6 \\
\hline & 2 & 5.610 & 264 & 449 & 8,0 \\
\hline & 3 & 5.675 & 291 & 613 & 10,8 \\
\hline & 4 & 5.745 & 339 & 596 & 10,4 \\
\hline \multirow{4}{*}{$150 \mathrm{kHz}$} & 1 & 5.418 & 282 & 582 & 12,3 \\
\hline & 2 & 5.548 & 94 & 175 & 3,2 \\
\hline & 3 & 5.383 & 143 & 249 & 4,6 \\
\hline & 4 & 5.457 & 194 & 380 & 7,0 \\
\hline \multirow{4}{*}{ Exponenciais } & 1 & 3.168 & 549 & 1068 & 33,7 \\
\hline & 2 & 2.369 & 487 & 845 & 35,7 \\
\hline & 3 & 3.098 & 585 & 1287 & 41,5 \\
\hline & 4 & 2.681 & 477 & 1039 & 38,8 \\
\hline
\end{tabular}


De acordo com o exposto na Tabela 6.5 é possível visualizar que os resultados das velocidades de propagação de ondas ultrassônicas utilizando-se os transdutores planos de $54 \mathrm{kHz}$ e $150 \mathrm{kHz}$ praticamente não sofrem alteração comparando-se a transmissão semidireta com a transmissão direta, somente na utilização dos transdutores exponenciais existe uma diminuição das velocidades.

Esperava-se que essa queda nos valores das velocidades fosse mais evidente considerando-se a forma de avaliação da transmissão semidireta que consiste do posicionamento dos transdutores em pontos perpendiculares.

Podemos observar também que os valores do desvio relativo máximo aumentam significativamente nesta forma de transmissão considerando-se os quatro operadores, o que demonstra que existe maior incerteza de medidas no uso da transmissão semidireta.

As Figuras 6.15 a 6.17 apresentam os gráficos dos resultados obtidos para cada ponto de leitura, bem como a variação de resultados encontrados.

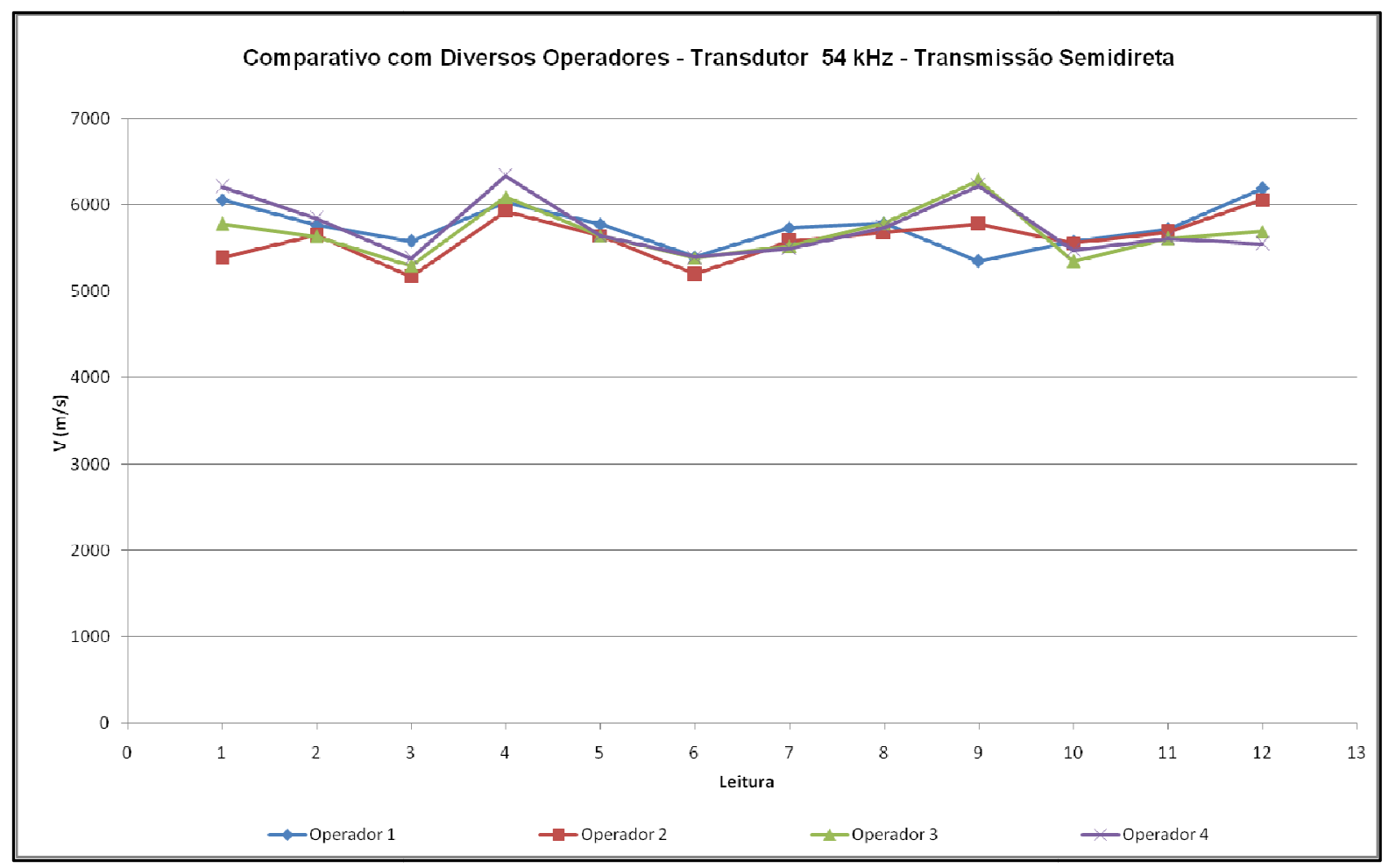

Figura 6.15 - Transmissão Semidireta - Transdutores de 54 kHz - Comparativo com diversos operadores. 


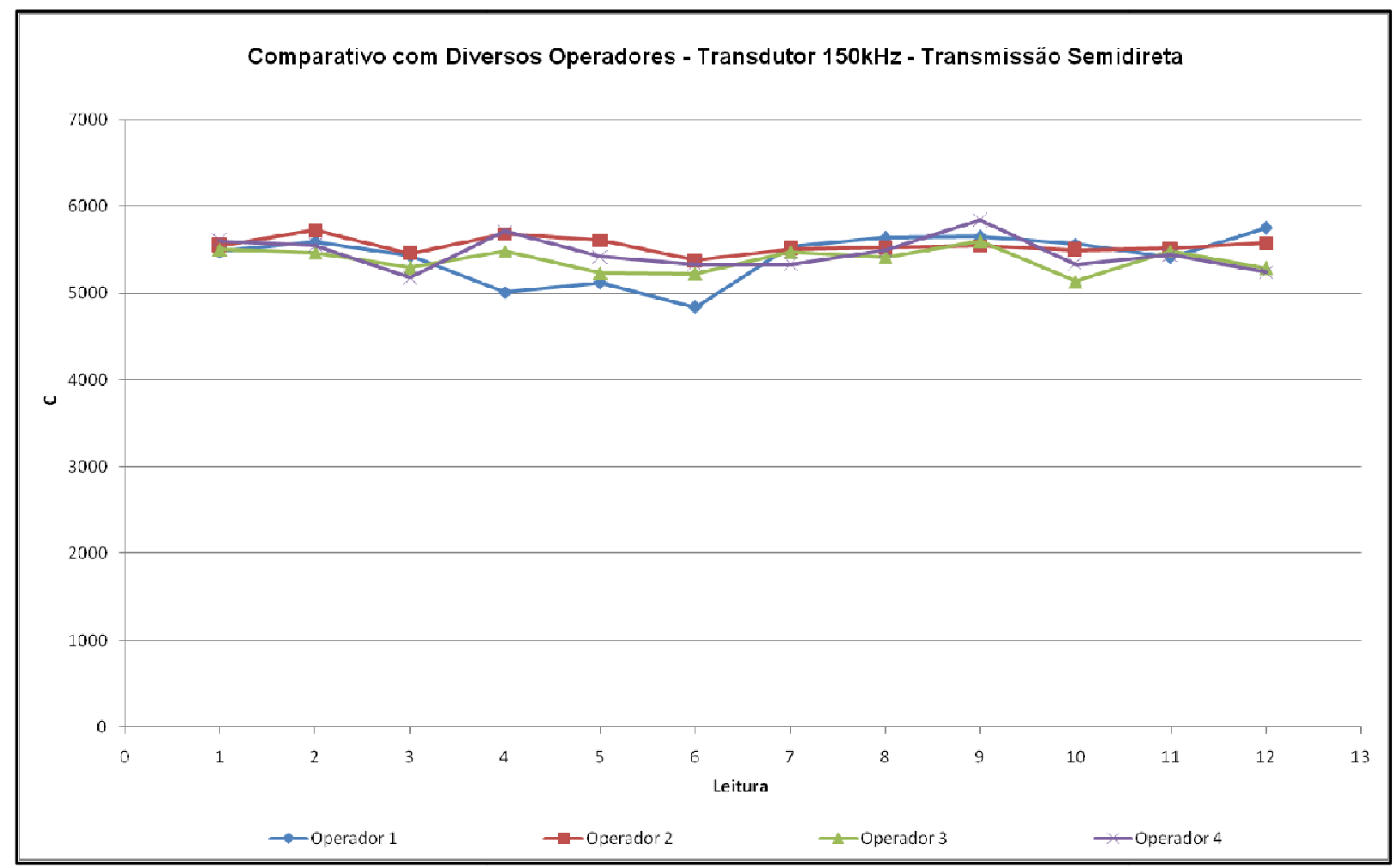

Figura 6.16 - Transmissão Semidireta - Transdutores de 150 kHz - Comparativo com diversos operadores.

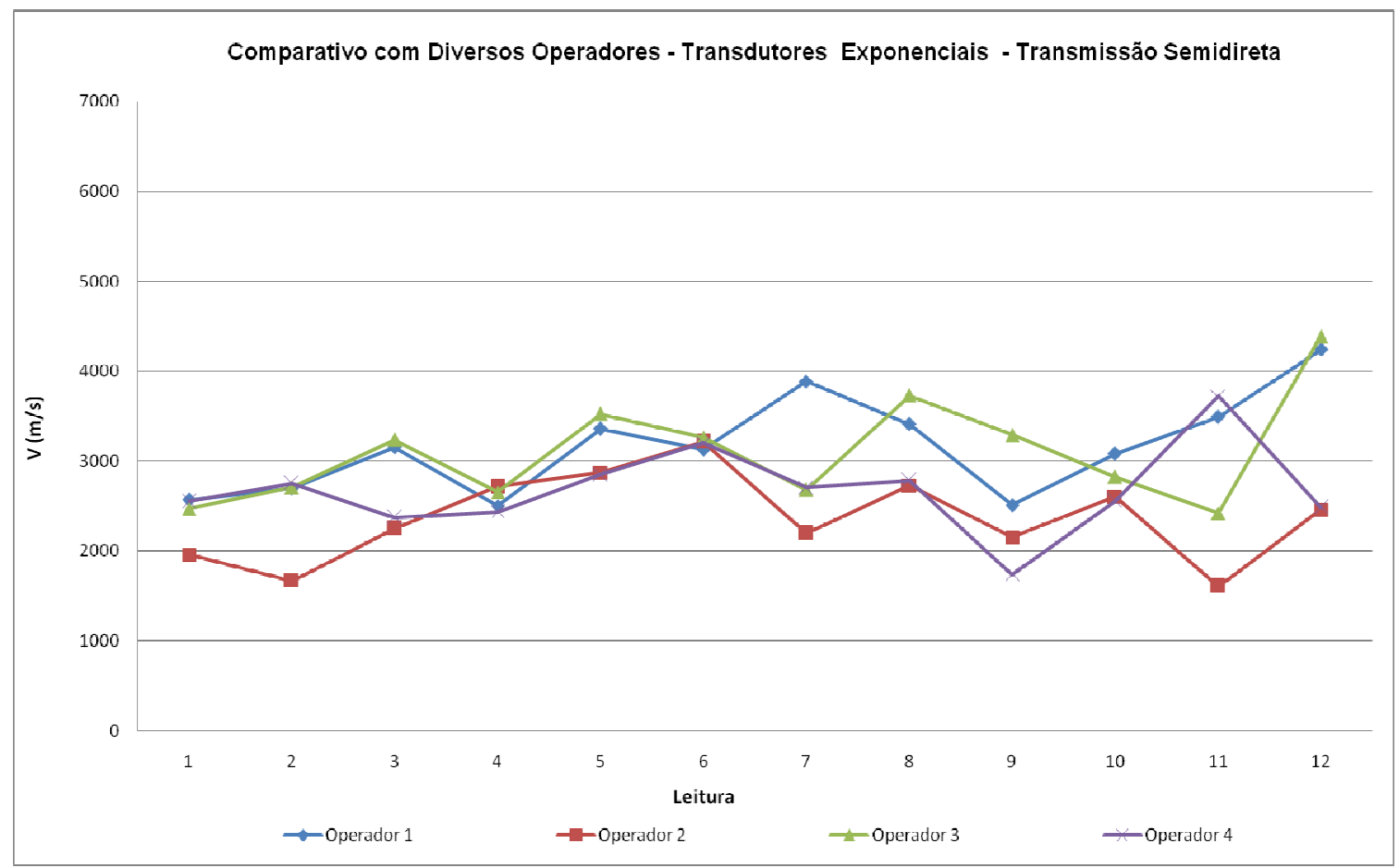

Figura 6.17 - Transmissão Semidireta- Transdutores Exponenciais - Comparativo com diversos operadores. 
Comparando os gráficos apresentados nas Figuras 6.15 a 6.17, conclui-se que o par de transdutores de $150 \mathrm{kHz}$ apresenta maior precisão entre os quatro operadores, os resultados levantados com os transdutores de $54 \mathrm{kHz}$ apresentam resultados próximos, porém mais dispersos.

Quanto aos transdutores exponenciais, a análise gráfica demonstra que os resultados não permitem um padrão de repetibilidade nos valores das velocidades de um mesmo operador, tornando-se mais evidente quando comparamos os quatro operadores, com confiabilidade de resultados praticamente nula.

A Tabela 6.6 apresenta os resultados obtidos através dos estudos realizados no comparativo entre diversos operadores pela transmissão indireta.

Tabela 6.6 - Resultados médios e desvios na análise da transmissão indireta no comparativo de diversos operadores.

\begin{tabular}{|c|c|c|c|c|c|}
\hline \multirow{3}{*}{ Transdutores } & Operador & $\begin{array}{c}\text { Velocidade } \\
\text { Média (m/s) }\end{array}$ & $\begin{array}{c}\text { Desvio } \\
\text { Padrão } \\
(\mathbf{m} / \mathbf{s})\end{array}$ & $\begin{array}{c}\text { Afastamento } \\
\text { Relativo (m/s) }\end{array}$ & $\begin{array}{c}\text { Desvio Relativo } \\
\text { Máximo (\%) }\end{array}$ \\
\hline \multirow{4}{*}{$\mathbf{5 4} \mathbf{~ k H z}$} & 1 & 5.439 & 275 & 577 & 10,6 \\
\cline { 2 - 6 } & 2 & 4.621 & 820 & 1211 & 26,2 \\
\cline { 2 - 6 } & 3 & 4.981 & 627 & 1628 & 32,7 \\
\cline { 2 - 6 } & 4 & 4.942 & 778 & 1745 & 35,3 \\
\hline \multirow{3}{*}{$\mathbf{1 5 0} \mathbf{~ k H z}$} & 1 & 5.233 & 149 & 295 & 5,6 \\
\cline { 2 - 6 } & 2 & 4.820 & 500 & 904 & 18,8 \\
\cline { 2 - 6 } & 3 & 4.948 & 262 & 548 & 11,1 \\
\hline \multirow{3}{*}{ Exponenciais } & 4 & 5.000 & 248 & 398 & 8,0 \\
\cline { 2 - 6 } & 2 & 2.959 & 280 & 513 & 17,3 \\
\cline { 2 - 6 } & 3 & 2.497 & 190 & 517 & 20,7 \\
\cline { 2 - 6 } & 4 & 2.626 & 270 & 609 & 14,4 \\
\hline
\end{tabular}

A avaliação comparativa pela transmissão indireta apresenta resultados mais dispersos, isolando cada operador. Na Tabela 6.6 fica visível a discrepância obtida pelos operadores através do resultado de desvio relativo máximo, no entanto novamente os transdutores planos de $150 \mathrm{kHz}$ apresentam melhores resultados comparados aos obtidos na utilização dos transdutores de $54 \mathrm{kHz}$.

Ainda analisando a Tabela 6.6 nota-se da mesma forma que na Tabela 6.3 que os resultados obtidos com os transdutores exponenciais atingem desvios relativos máximos inferiores aos obtidos pela transmissão direta e semidireta.

A análise gráfica das Figuras 6.18 a 6.20 configura uma melhor disposição de resultados na utilização dos transdutores de $150 \mathrm{kHz}$, seguidos pelos transdutores 
exponenciais que embora apresentem velocidades de propagação de onda discrepantes aos outros dois pares de transdutores, apresentam resultados com maior precisão comparando-se os operadores, o que pode ser confirmado pelos resultados dos desvios relativos máximos apresentados anteriormente na Tabela 6.6.

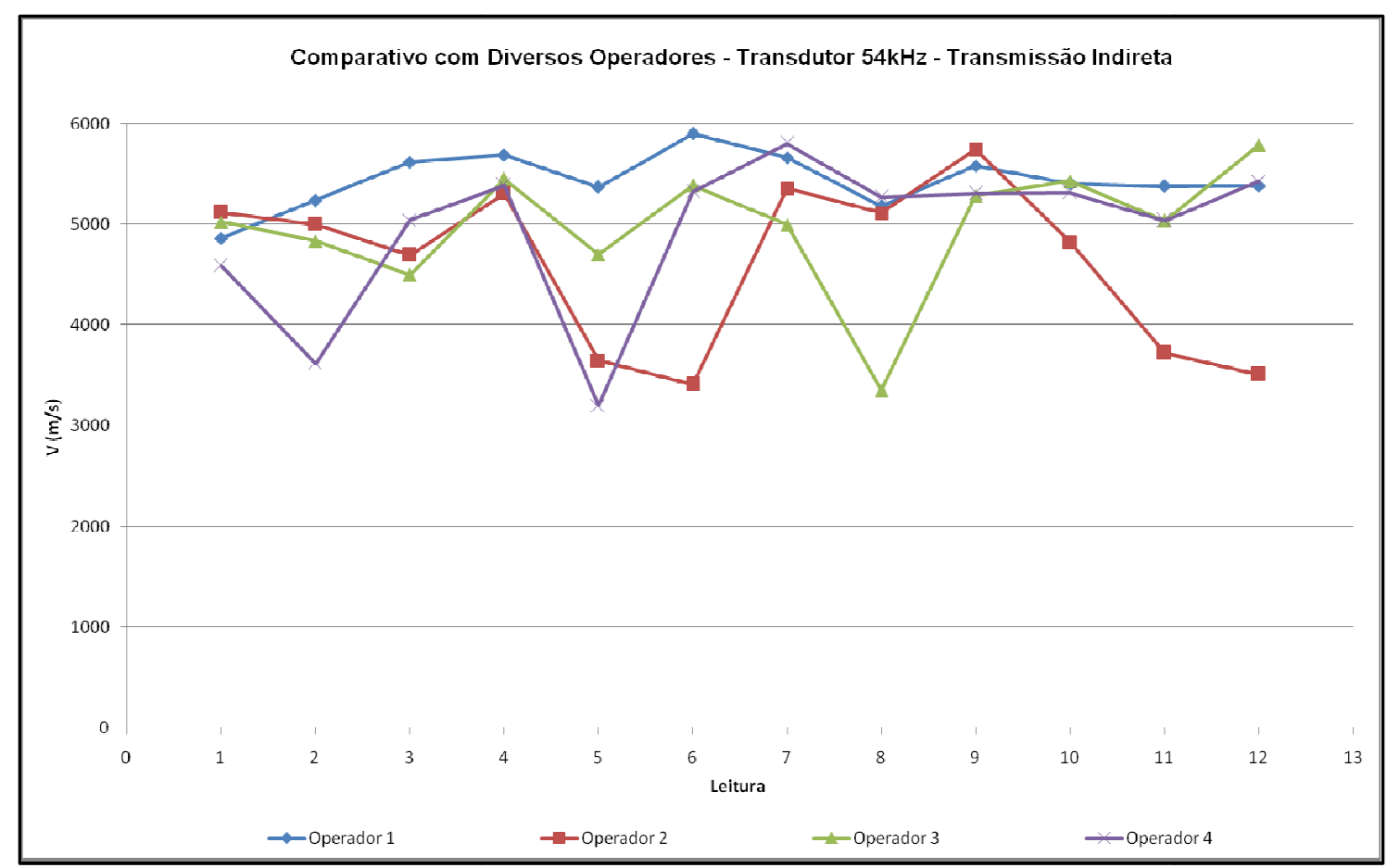

Figura 6.18 - Transmissão Indireta - Transdutores de 54 kHz - Comparativo com diversos operadores.

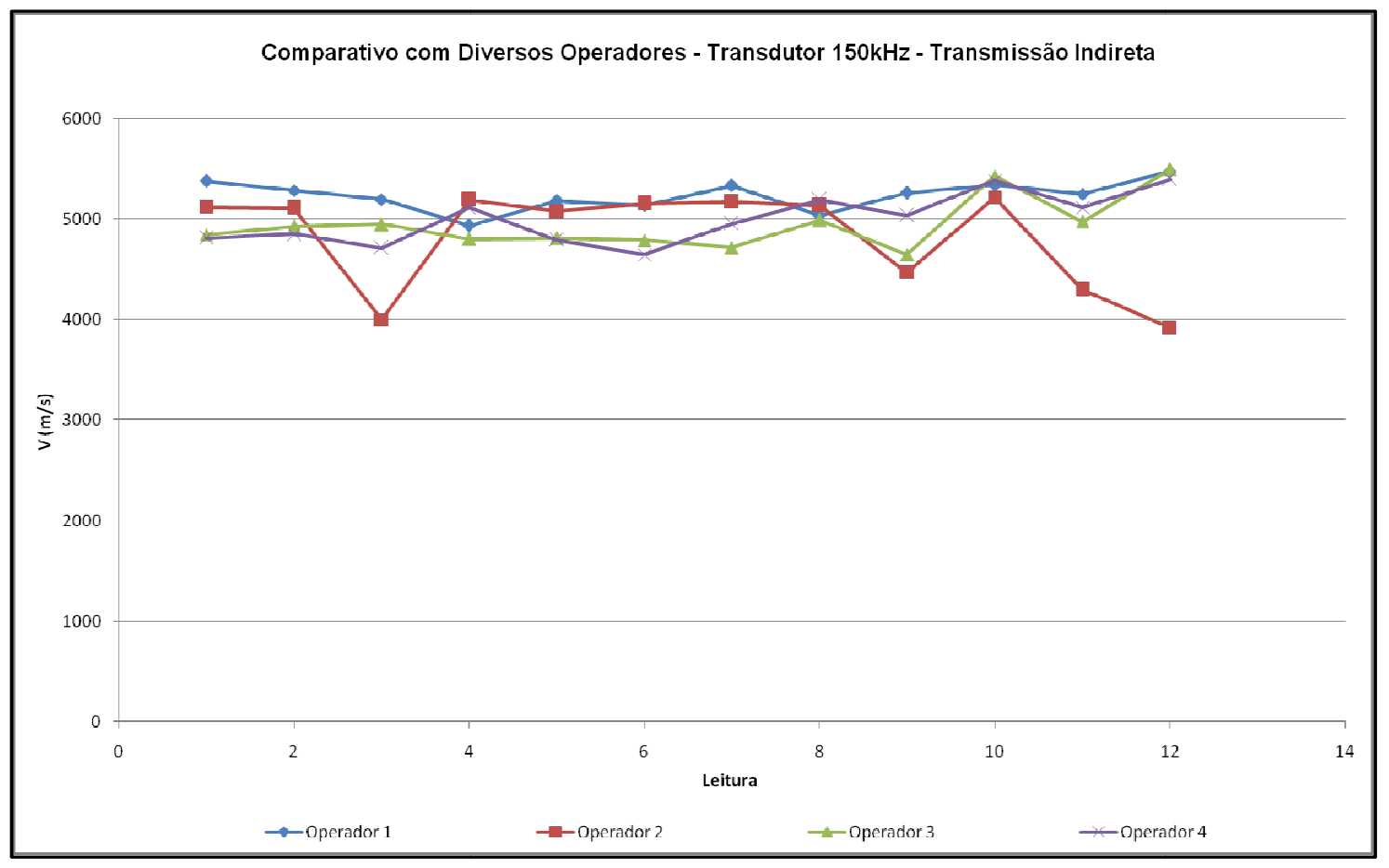

Figura 6.19 - Transmissão Indireta - Transdutores de 150 kHz - Comparativo com diversos operadores. 


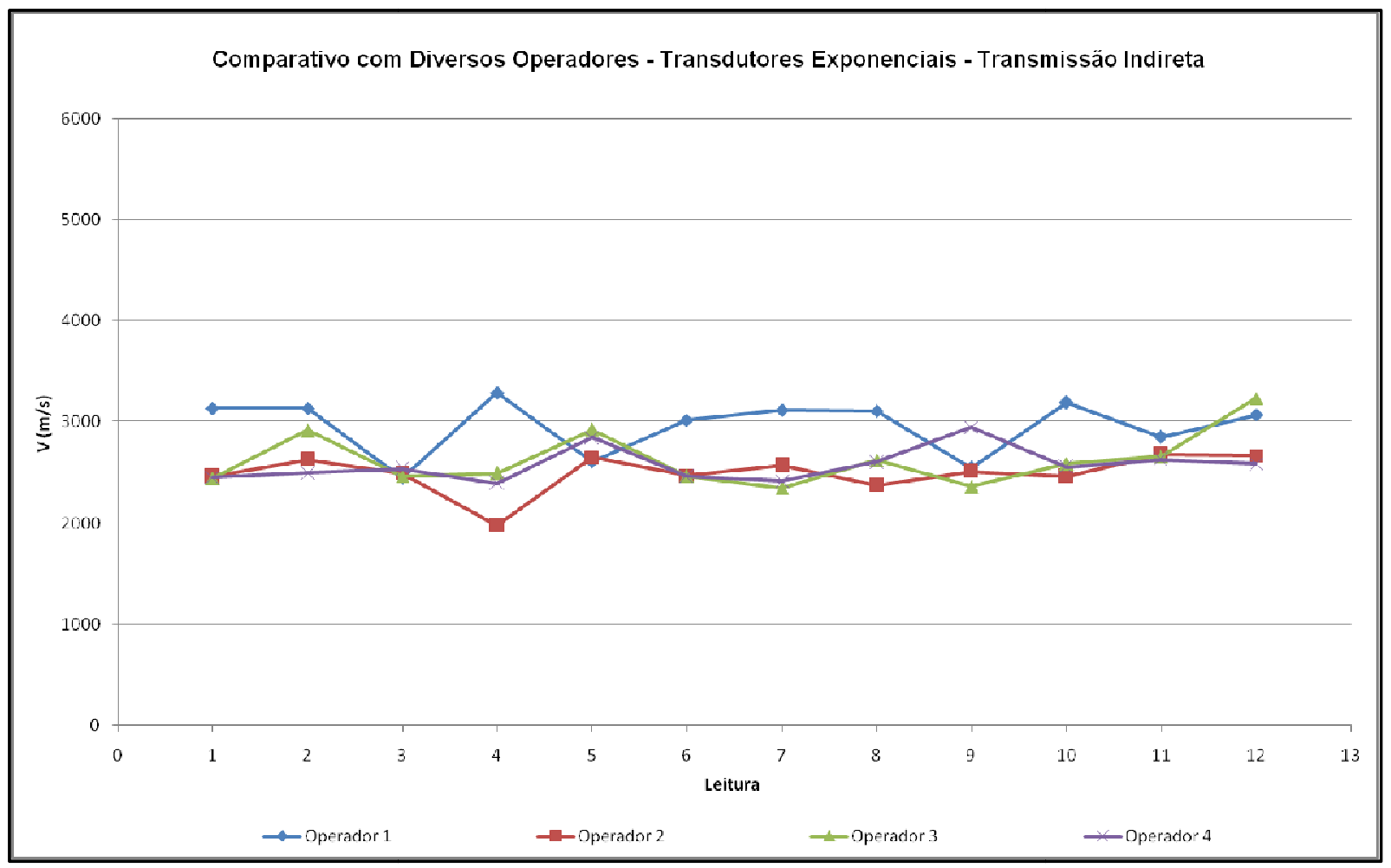

Figura 6.20 - Transmissão Indireta - Transdutores Exponenciais - Comparativo com diversos operadores.

O comparativo entre os operadores favoreceu a visualização de que mesmo em condições favoráveis para a análise pelo método de propagação de ondas ultrassônicas é possível a ocorrência de variações nos resultados de um mesmo operador ou entre operadores.

A Tabela 6.7 também nos permite observar a perda de precisão nas leituras nos diferentes tipos de transmissão. Se avaliarmos os transdutores planos de $54 \mathrm{kHz}$ e $150 \mathrm{kHz}$, notamos que existe aumento dos valores do desvio padrão e desvio relativo máximo quanto menor o alinhamento dos transdutores, ou seja, os resultados comprovam fisicamente que a transmissão direta é a que apresenta os valores mais estáveis seguida pela transmissão semidireta e indireta, respectivamente. Embora os transdutores exponenciais não apresentem este mesmo padrão dadas as dificuldades encontradas, na utilização dos mesmos estes não foram considerados nesta observação. 
Tabela 6.7 - Valores mínimos e máximos dos resultados da velocidade média, desvio padrão e desvio relativo máximo referente ao comparativo entre quatro operadores.

\begin{tabular}{|c|c|c|c|c|c|c|c|}
\hline \multirow{2}{*}{ Transdutores } & \multirow{2}{*}{ Transmissão } & \multicolumn{2}{|c|}{$\begin{array}{c}\text { Velocidade Média } \\
(\mathbf{m} / \mathbf{s})\end{array}$} & \multicolumn{2}{c|}{$\begin{array}{c}\text { Desvio Padrão } \\
(\mathbf{m} / \mathbf{s})\end{array}$} & \multicolumn{2}{c|}{$\begin{array}{c}\text { Desvio Relativo } \\
\text { Máximo (\%) }\end{array}$} \\
\cline { 3 - 8 } & & Min. & Máx. & Min. & Máx. & Min. & Máx. \\
\hline \multirow{4}{*}{$\mathbf{5 4} \mathbf{~ k H z}$} & Direta & 5.237 & 5.542 & 61,2 & 134,0 & 1,5 & 2,9 \\
\cline { 2 - 8 } & Semidireta & 5.439 & 5.745 & 263,8 & 338,5 & 8,0 & 10,8 \\
\cline { 2 - 8 } & Indireta & 4.621 & 5.439 & 274,8 & 777,8 & 10,6 & 35,3 \\
\hline \multirow{3}{*}{$\mathbf{1 5 0} \mathbf{~ k H z}$} & Direta & 5.391 & 5.549 & 36,3 & 141,6 & 1,0 & 3,3 \\
\cline { 2 - 8 } & Semidireta & 5.233 & 5.548 & 93,9 & 193,9 & 3,2 & 7,0 \\
\cline { 2 - 8 } & Indireta & 4.820 & 5.233 & 149,0 & 499,8 & 5,6 & 18,8 \\
\hline \multirow{3}{*}{ Exponenciais } & Direta & 2.990 & 3.488 & 584,0 & 755,5 & 21,2 & 31,4 \\
\cline { 2 - 7 } & Semidireta & 2.369 & 3.098 & 279,5 & 584,8 & 17,3 & 41,5 \\
\cline { 2 - 7 } & Indireta & 2.497 & 2.959 & 168,4 & 280,0 & 14,4 & 23,2 \\
\hline
\end{tabular}

\subsection{Avaliações no Monumento às Bandeiras}

\subsubsection{Transmissão Direta}

As avaliações das velocidades de propagação de ondas ultrassônicas no Monumento às Bandeiras pela transmissão direta ocorreram em três etapas, as duas primeiras etapas contemplaram a determinação dos pontos de leitura e da execução das medidas no entorno das figuras constituintes do Monumento às Bandeiras pela transmissão direta utilizando-se os três pares de transdutores, $54 \mathrm{kHz}, 150 \mathrm{kHz}$ e exponenciais, buscando-se o maior numero de pontos passíveis da aplicação do método.

O critério de avaliação para determinação dos pontos foram as dimensões, rugosidade superficial e alcance do operador, pois não se dispunha de equipamentos adequados para efetuar medidas em locais com alturas superiores ao alcance dos braços.

Nas primeiras leituras efetuadas in loco, foram determinados 10 pontos na face direita do monumento considerando-se a referência da vista frontal, conforme locais expostos na Tabela 6.8 e Figura 6.21, e resultados na Tabela 6.9. Na segunda etapa definiram-se 14 pontos de leitura no lado esquerdo do monumento conforme Tabela $6.10 \mathrm{e}$ Figura 6.22.

A terceira etapa de avaliações do monumento ocorreu pela necessidade de confirmar leituras em pontos que apresentaram resultados muito discrepantes às tendências dos pontos, na qual foram repetidos 8 pontos.

O posicionamento preciso dos dez pontos avaliados no lado direito do Monumento às Bandeiras estão apresentados na Tabela 6.8. É importante ressaltar que esta face do 54 
monumento está no sentido sudoeste, sendo a face que recebe menor insolação ao longo do dia.

Tabela 6.8 - Nomenclatura dos Pontos e Local das Leituras Realizadas no Monumento às Bandeiras na primeira etapa de medição, Face Direita da Vista Frontal.

\begin{tabular}{|c|c|}
\hline Nome do Ponto & DESCRIÇÃO DO PONTO \\
\hline PONTO 1 & Tornozelo direito da 1a figura \\
\hline PONTO 2 & Logo abaixo do joelho esquerdo da 1 a figura \\
\hline PONTO 3 & Logo abaixo do joelho esquerdo da 2 a figura \\
\hline PONTO 4 & Logo abaixo do joelho esquerdo da 3a figura \\
\hline PONTO 5 & Mão esquerda da 4 a figura \\
\hline PONTO 6 & Cajado da 6 a figura - Ponto mais alto \\
\hline PONTO 7 & Cajado da 6a figura - Ponto médio \\
\hline PONTO 8 & Cajado da 6a figura - Ponto mais baixo \\
\hline PONTO 9 & Panturrilha da perna esquerda da 7a figura \\
\hline PONTO 10 & Tornozelo esquerdo da 1a figura após o "deitado" \\
\hline
\end{tabular}

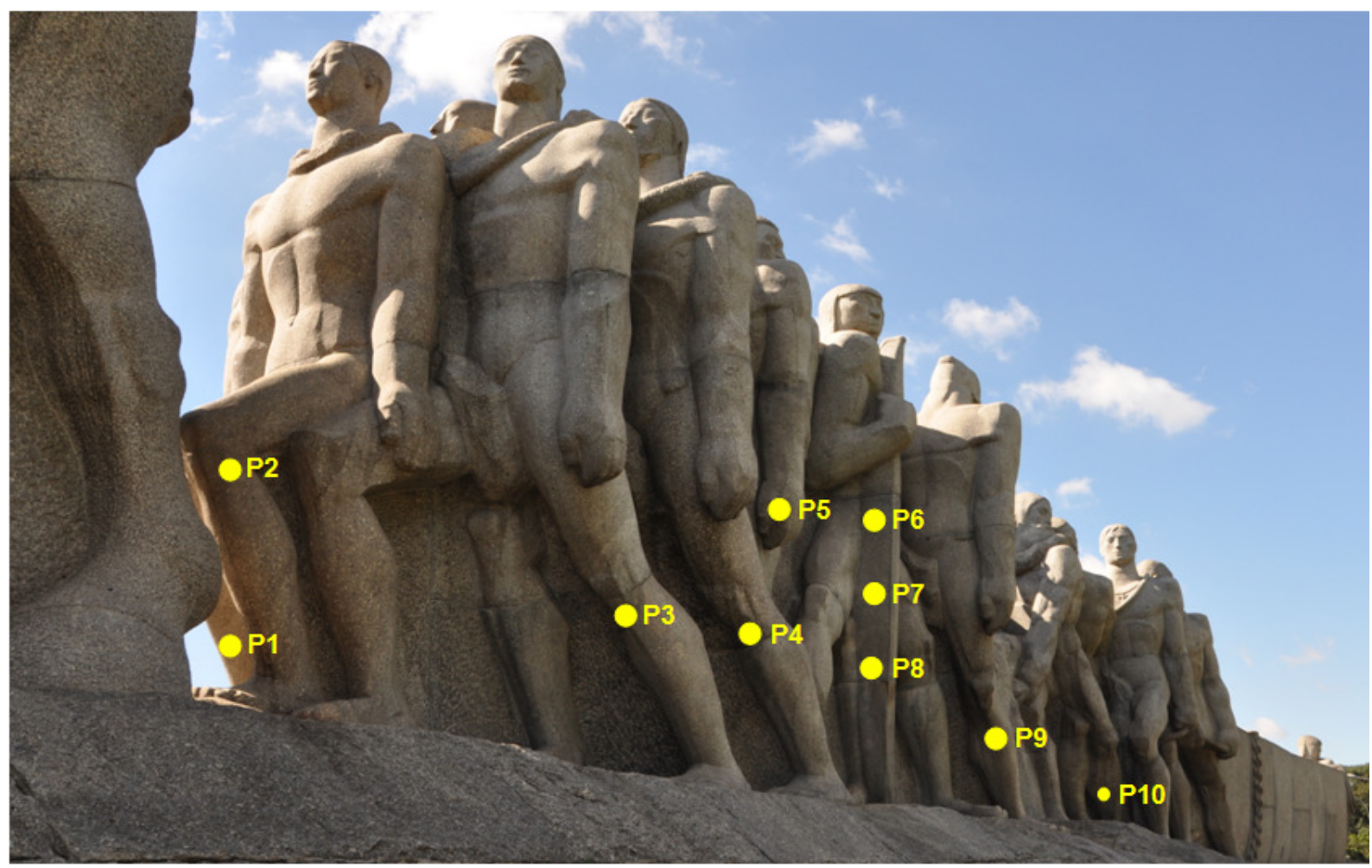

Figura 6.21 - Distribuição dos Pontos de Leitura no Lado Direito do Monumento às Bandeiras. Foto: Lauro K. Dehira.

Os resultados médios determinados nesta etapa apresentam diferenças relativamente grandes entre os três tipos de transdutores, conforme exposto na Tabela 6.9, 
o que não ocorria no laboratório entre os transdutores de $54 \mathrm{kHz}$ e $150 \mathrm{kHz}$. Quanto à discrepância do valor médio encontrado na utilização dos transdutores exponenciais, esta já era esperada, considerando-se o comportamento instável de sua utilização em laboratório.

Tabela 6.9 - Resultados médios e desvios nas análises do Monumento às Bandeiras pela transmissão direta realizadas na primeira etapa de medição.

\begin{tabular}{ccccc}
\hline Transdutores & $\begin{array}{c}\text { Velocidade } \\
\text { Média }(\mathbf{m} / \mathbf{s})\end{array}$ & $\begin{array}{c}\text { Desvio Padrão } \\
(\mathbf{m} / \mathbf{s})\end{array}$ & $\begin{array}{c}\text { Afastamento Relativo } \\
(\mathbf{m} / \mathbf{s})\end{array}$ & $\begin{array}{c}\text { Desvio Relativo } \\
\text { Máximo (\%) }\end{array}$ \\
\hline $\mathbf{5 4} \mathbf{~ k H z}$ & 3.707 & 1446 & 1907 & 51,4 \\
\hline $\mathbf{1 5 0} \mathbf{~ k H z}$ & 4.728 & 671 & 1922 & 40,7 \\
Exponenciais & 2.022 & 651 & 1313 & 64,9 \\
\hline
\end{tabular}

Considerando-se os valores dos desvios, é visível que os transdutores de $54 \mathrm{kHz}$ obtiveram desvio padrão muito elevado, e também que o valor do desvio relativo máximo apresenta-se mais elevado se comparado aos transdutores de $150 \mathrm{kHz}$.

Embora as leituras efetuadas com os transdutores de $150 \mathrm{kHz}$ tenham apresentado desvios relativamente altos, dentre os pares de transdutores utilizados, estes foram os mais estáveis na determinação da velocidade de propagação de onda ultrassônica.

Quanto às leituras com os transdutores exponenciais, devido ao seu comportamento insatisfatório de resultados obtidos no laboratório e nas primeiras avaliações do Monumento às Bandeiras, estes deixaram de ser utilizados nos estudos seguintes.

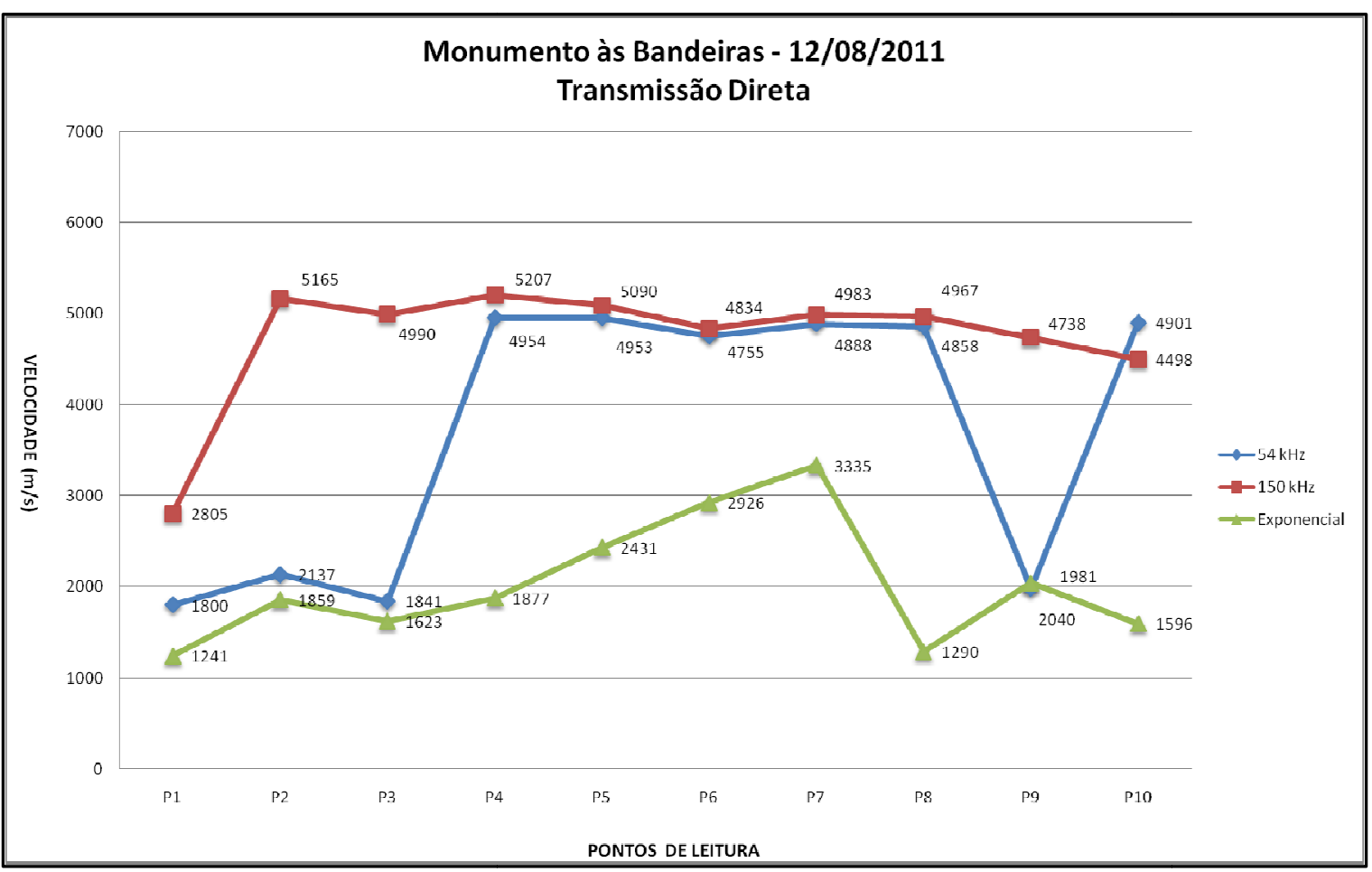

Figura 6.22 - Leituras efetuadas pela transmissão direta no Monumento às Bandeiras na primeira etapa. 
Avaliando o gráfico exposto na Figura 6.22 das leituras realizadas na primeira etapa de avaliações no monumento, é possível notar uma maior estabilidade nos resultados efetuados com os transdutores de $150 \mathrm{kHz}$, excetuando-se o ponto $\mathrm{P} 1$.

Os resultados obtidos com os transdutores de $54 \mathrm{kHz}$ demonstram que as leituras efetuadas nos pontos P1, P2, P3 e P9 apresentam resultados que se distanciam agressivamente da tendência dos demais, o que gera valores de desvio padrão e desvio relativo máximo elevados e com resultado médio da velocidade muito inferior ao esperado, dado o comportamento do par de transdutores de $150 \mathrm{kHz}$.

Esta ocorrência pode ser justificada em função da área de contato dos transdutores de $54 \mathrm{kHz}$, pois por possuírem superfícies planas com área superior à dos transdutores de $150 \mathrm{kHz}$ sofrem atenuação da emissão e recepção da onda ultrassônica, sendo as curvaturas ou imperfeições da superfície do monumento geradoras de erros nas leituras, causadas por conta da interferência do acoplamento dos transdutores à base.

$\mathrm{Na}$ segunda etapa de avaliação no Monumento às Bandeiras foram determinados 14 pontos distintos de leitura no lado esquerdo do monumento baseando-se da vista frontal do mesmo (Figura 6.23). A localização precisa dos pontos e suas nomenclaturas constam na Tabela 6.10.

Tabela 6.10 - Nomenclatura dos Pontos e Local das Leituras Realizadas no Monumento às Bandeiras na segunda etapa de medições, Face Esquerda da Vista Frontal.

\begin{tabular}{|c|c|}
\hline Nome do Ponto & DESCRIÇÃO DO PONTO \\
\hline PONTO 11 & $2^{\text {a }}$ Figura - joelho esquerdo \\
\hline PONTO 12 & $2^{\mathrm{a}}$ Figura- mão direita \\
\hline PONTO 13 & $3^{\text {a }}$ Figura - perna direita \\
\hline PONTO 14 & $3^{\text {a }}$ Figura - mão direita \\
\hline PONTO 15 & $5^{\circ}$ Figura - tornozelo direito \\
\hline PONTO 16 & Índia com bebê - joelho direito \\
\hline PONTO 17 & Mulher com gamela - joelho direito \\
\hline PONTO 18 & Penúltima Figura (lateral do barco) - perna esquerda \\
\hline PONTO 19 & Penúltima Figura (lateral do barco) - coxa esquerda \\
\hline PONTO 20 & Penúltima Figura (lateral do barco) - perna direita \\
\hline PONTO 21 & Ultima Figura - perna esquerda (coxa logo acima do joelho) \\
\hline PONTO 22 & Ultima- panturrilha esquerda \\
\hline PONTO 23 & Ultima - tornozelo esquerdo \\
\hline PONTO 24 & Ultima - antebraço direito \\
\hline
\end{tabular}




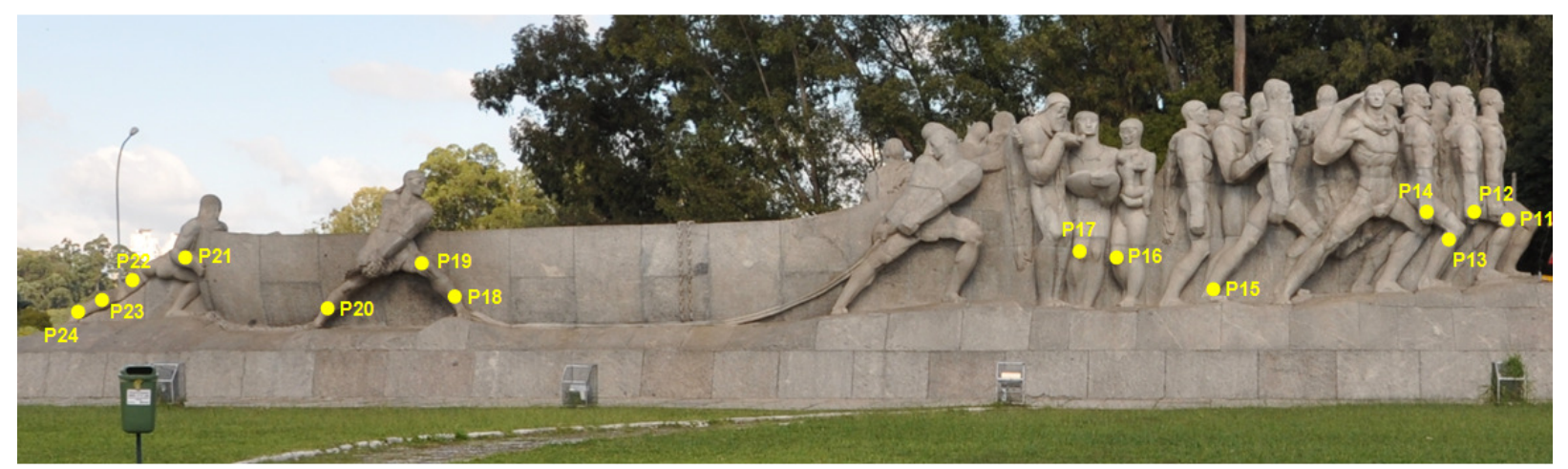

Figura 6.23 - Distribuição dos Pontos de Leitura no Lado esquerdo do Monumento às Bandeiras. Foto: Lauro K. Dehira.

Diferentemente do ocorrido na primeira etapa de análises no monumento, os resultados médios da velocidade de propagação de ondas ultrassônicas obtidos nas avaliações realizadas na segunda etapa apresentaram-se mais próximos comparando-se os dois pares de transdutores de $54 \mathrm{kHz}$ e $150 \mathrm{kHz}$, conforme exposto na Tabela 6.11.

Tabela 6.11 - Resultados médios e desvios nas análises do Monumento às Bandeiras pela transmissão direta realizadas na segunda etapa de medições.

\begin{tabular}{ccccc}
\hline Transdutores & $\begin{array}{c}\text { Velocidade } \\
\text { Média }(\mathbf{m} / \mathbf{s})\end{array}$ & $\begin{array}{c}\text { Desvio Padrão } \\
(\mathbf{m} / \mathbf{s})\end{array}$ & $\begin{array}{c}\text { Afastamento Relativo } \\
(\mathbf{m} / \mathbf{s})\end{array}$ & $\begin{array}{c}\text { Desvio Relativo } \\
\text { Máximo (\%) }\end{array}$ \\
\hline $\mathbf{5 4} \mathbf{~ k H z}$ & 4.265 & 833 & 2377 & 55,7 \\
\hline $\mathbf{1 5 0} \mathbf{~ k H z}$ & 4.384 & 444 & 863 & 19,7 \\
\hline
\end{tabular}

Novamente os valores referentes ao desvio padrão e desvio relativo máximo apresentaram-se muito altos nas avaliações efetuadas com o transdutor de $54 \mathrm{kHz}$, no caso das avaliações com os transdutores de $150 \mathrm{kHz}$ estes desvios apresentaram resultados satisfatórios.

Avaliando o ocorrido no gráfico exibido na Figura 6.24 é possível concluir que o ponto P13 influenciou os resultados dos desvios para o transdutor de $54 \mathrm{kHz}$, sendo que os pontos P16, P22 e P23 também apresentaram discrepância nos valores das velocidades comparando os dois pares de transdutores. 


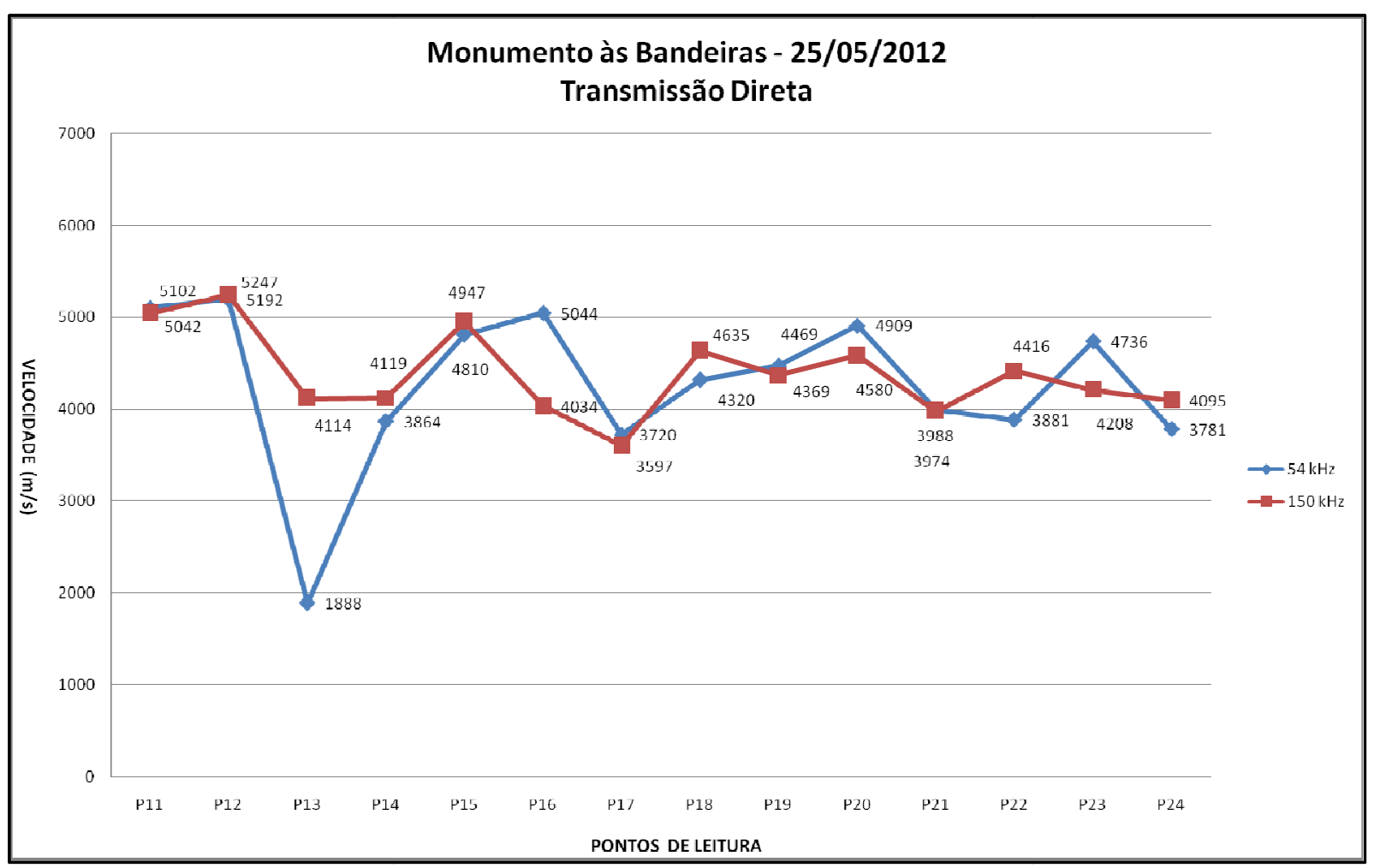

Figura 6.24 - Leituras efetuadas pela transmissão direta no Monumento às Bandeiras na segunda etapa de medição.

Embora os valores obtidos de velocidade de propagação de onda ultrassônica tenham sido determinados em etapas diferentes, considerou-se fundamental uma avaliação global dos valores coletados. Assim, a Tabela 6.12 apresenta os valores e desvios referentes a todos os pontos avaliados in loco com os transdutores de $54 \mathrm{kHz}$ e $150 \mathrm{kHz}$.

Tabela 6.12 - Resultados médios e desvios considerando todos os valores coletados do Monumento às Bandeiras pela transmissão direta.

\begin{tabular}{ccccc}
\hline Transdutores & $\begin{array}{c}\text { Velocidade } \\
\text { Média }(\mathrm{m} / \mathrm{s})\end{array}$ & $\begin{array}{c}\text { Desvio Padrão } \\
(\mathrm{m} / \mathrm{s})\end{array}$ & $\begin{array}{c}\text { Afastamento Relativo } \\
(\mathrm{m} / \mathrm{s})\end{array}$ & $\begin{array}{c}\text { Desvio Relativo } \\
\text { Máximo }(\%)\end{array}$ \\
\hline $54 \mathrm{kHz}$ & 4.032 & 1188 & 2232 & 55,4 \\
$150 \mathrm{kHz}$ & 4.527 & 588 & 1722 & 38,0 \\
\hline
\end{tabular}

Quando efetuamos a análise integra todos os valores adquiridos no Monumento às Bandeiras em um único grupo obtemos resultados pouco confiáveis, pois os resultados das velocidades médias apresentavam valores consideravelmente distintos entre os dois pares de transdutores, o que ocorre também avaliando os valores dos desvios utilizados para análise. 
De acordo com a Tabela 6.12 é notório que os resultados colhidos com os transdutores de $54 \mathrm{kHz}$ apresentam desvios mais expressivos, não atingindo uma regularidade de resultados.

Avaliando o gráfico exposto na Figura 6.25, fica claro que os pontos onde as velocidades de propagação de ondas ultrassônicas são inferiores a $3.000 \mathrm{~m} / \mathrm{s}$ estão influenciando significativamente os resultados médios da velocidade de cada par de transdutores, bem como os valores dos desvios.

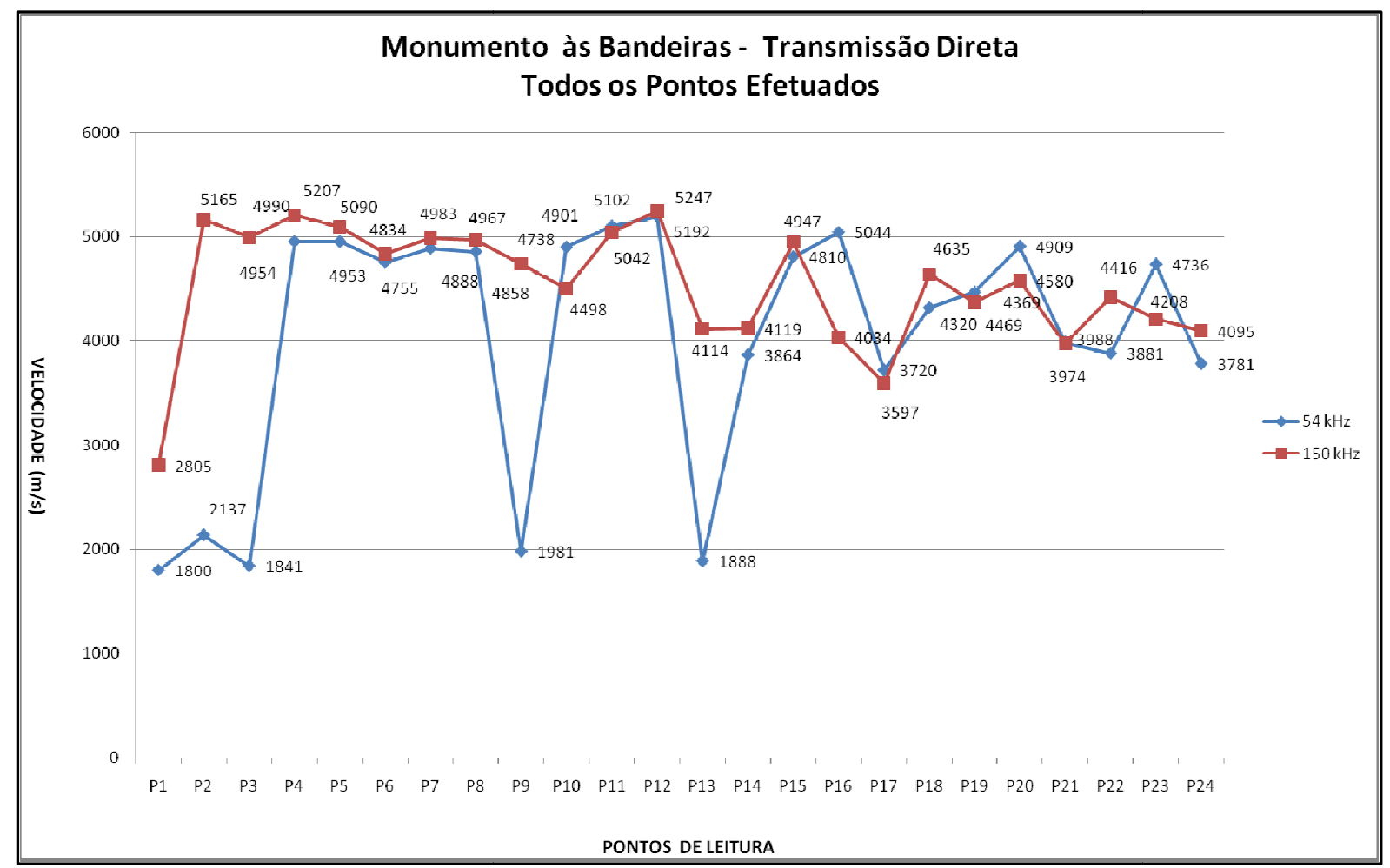

Figura 6.25 - Resultados de todas as leituras efetuadas pela transmissão direta no Monumento às Bandeiras.

Em alguns pontos notamos que os resultados entre os pares de transdutores de 54 kHz e de $150 \mathrm{kHz}$ são extremamente incompatíveis, o que pode caracterizar falha na operação nas avaliações efetuadas em campo.

Em função destes resultados discrepantes foi definida a terceira etapa de avaliações no Monumento às Bandeiras que consistiu em repetir as leituras efetuadas anteriormente onde os resultados das velocidades foram insatisfatórios.

Dessa forma buscou-se determinar se a falha foi na operação durante as leituras, ou se estes locais realmente influenciaram os resultados utilizando pares de transdutores diferentes, pois em muitos casos curvaturas e superfícies irregulares podem favorecer as leituras com os transdutores de $150 \mathrm{kHz}$ e prejudicar as leituras com os transdutores de 60 
$54 \mathrm{kHz}$ em função da diferença na área de contato dos mesmos, ou até presença de descontinuidades na rocha.

A Tabela 6.13 apresenta os pontos e locais de análises onde as leituras foram repetidas. Os pontos das leituras repetidas serão denominados pela letra "P" juntamente com o número do ponto repetido, acompanhados da letra "C" que significa "correção".

Tabela 6.13 - Leituras repetidas no Monumento às Bandeiras em 03/08/2012 para correção das análises.

\begin{tabular}{|c|c|c|}
\hline Nome do Ponto & $\begin{array}{c}\text { Lado do } \\
\text { Monumento }\end{array}$ & DESCRIÇÃO DO PONTO \\
\hline P1C & Direito & Tornozelo direito da $1^{\underline{a}}$ figura \\
\hline P2C & Direito & Logo abaixo do joelho esquerdo da $1^{a}$ figura \\
\hline P3C & Direito & Logo abaixo do joelho esquerdo da $2^{\mathrm{a}}$ figura \\
\hline P9C & Direito & Panturrilhada perna esquerda da $7^{a}$ figura \\
\hline P13C & Esquerdo & $3^{a}$ Figura - perna direita \\
\hline P16C & Esquerdo & Ìndia com bebê - joelho direito \\
\hline P22C & Esquerdo & Ultima- panturrilha esquerda \\
\hline P23C & Esquerdo & Ultima - tornozelo esquerdo \\
\hline
\end{tabular}

Após efetuarmos as leituras para correções, os valores anteriormente adquiridos no monumento, relativos aos pontos repetidos foram substituídos na determinação dos valores das velocidades médias para cada par de transdutores, de forma a obtenção de novas médias e desvios conforme a Tabela 6.14.

Tabela 6.14 - Resultados médios e desvios considerando todos os valores coletados no Monumento às Bandeiras pela transmissão direta após repetir leituras para correção.

\begin{tabular}{ccccc}
\hline Transdutores & $\begin{array}{c}\text { Velocidade } \\
\text { Média (m/s) }\end{array}$ & $\begin{array}{c}\text { Desvio Padrão } \\
(\mathbf{m} / \mathbf{s})\end{array}$ & $\begin{array}{c}\text { Afastamento Relativo } \\
(\mathbf{m} / \mathbf{s})\end{array}$ & $\begin{array}{c}\text { Desvio Relativo } \\
\text { Máximo (\%) }\end{array}$ \\
\hline $\mathbf{5 4} \mathbf{~ k H z}$ & 4.498 & 845 & 2876 & 63,9 \\
$\mathbf{1 5 0} \mathbf{~ k H z}$ & 4.598 & 470 & 1001 & 21,8 \\
\hline
\end{tabular}

A Tabela 6.14 demonstra que repetir as leituras mais discrepantes favoreceu um resultado médio da velocidade mais aproximado entre os dois pares de transdutores, ocorreu também uma redução considerável nos valores do desvio padrão para ambos, no entanto o desvio relativo máximo para os transdutores de $150 \mathrm{kHz}$ atinge uma taxa próxima a $20 \%$ o que representa que todos os valores adquiridos encontram-se entre $80 \%$ a $120 \%$ da média, o que podemos considerar uma taxa de erro aceitável, já os transdutores de 
$54 \mathrm{kHz}$ atingem um desvio relativo máximo mais elevado que nas avaliações anteriores, em uma ordem superior a $60 \%$, ou seja, uma taxa de erro muito elevada.

A Figura 6.26 demonstra que mesmo após a repetição das leituras dos pontos P1C, P2C, P3C, P9C, P13C, P16C, P22C e P23C, os pontos P2C e P22C apresentam resultados muito discrepantes comparando-se os transdutores de $54 \mathrm{kHz}$ e $150 \mathrm{kHz}$, os valores adquiridos para o par de transdutores de $150 \mathrm{kHz}$ demonstram-se adequados, no entanto estes dois pontos apresentam valores que se afastam consideravelmente da média obtida para os transdutores de $54 \mathrm{kHz}$.

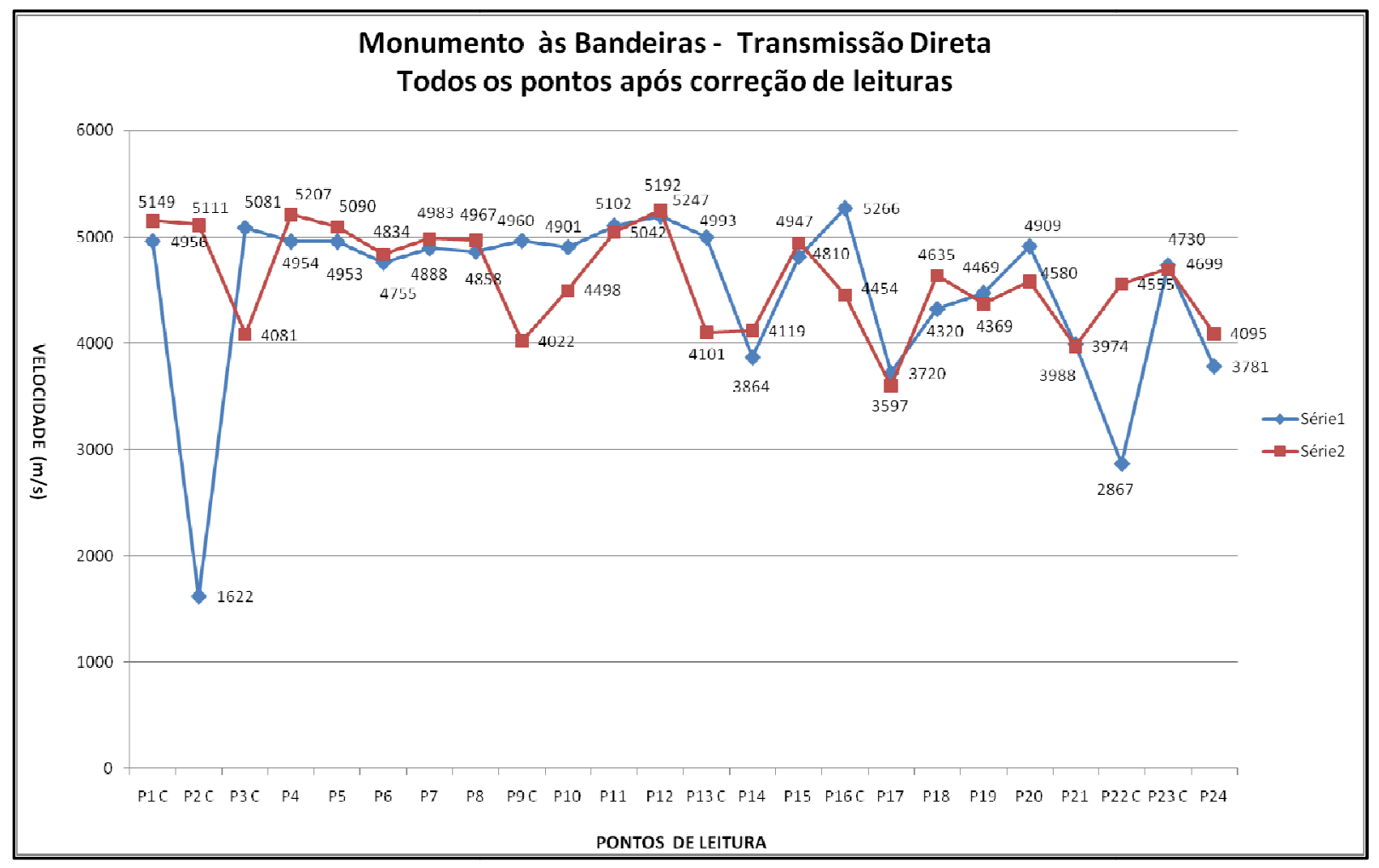

Figura 6.26 - Resultados de todas as leituras efetuadas pela transmissão direta no Monumento às Bandeiras após repetição de leituras para correção de valores.

De forma a minimizar os desvios os pontos P2C e P22C, serão desconsiderados da amostragem de ambos os pares de transdutores para a determinação de uma nova média buscando reduzir a incerteza de medição e excluiremos todos os resultados para cada par de transdutores que exceda $20 \%$ de afastamento em relação à média obtida após a exclusão dos pontos $\mathrm{P} 2 \mathrm{C}$ e $\mathrm{P} 22 \mathrm{C}$, assim obteremos valores com um desvio relativo máximo na ordem de $20 \%$, mantendo somente os valores estáveis de leitura.

Aplicando-se o caráter da exclusão dos pontos mais discrepantes pela análise gráfica, onde foram excluídos os pontos P2C e P22C atingimos valores de velocidade 
médios de $4.702 \mathrm{~m} / \mathrm{s}$ para os transdutores de $54 \mathrm{kHz}$ e de $4.577 \mathrm{~m} / \mathrm{s}$ para os transdutores de $150 \mathrm{kHz}$, sobre esses valores foi efetuada a exclusão das leituras que se afastaram em mais de $20 \%$ da média para mais ou para menos, onde foi excluído mais um ponto de leitura, o P17, no limite inferior de ambos os pares de transdutores.

Dessa forma atingimos os resultados finais da avaliação da propagação de ondas ultrassônicas no Monumento às Bandeiras, onde alcançamos valores médios das velocidades com diferenças entre os pares de transdutores de $2,7 \%$, desvio padrão muito aproximado para ambos e desvio relativo máximo com valores inferiores a $20 \%$, sendo este desvio de 14,5\% para os transdutores de $150 \mathrm{kHz}$. Do total de 24 pontos de leitura efetuados, foram eliminados do cálculo final apenas resultados equivalentes a três pontos o que caracteriza um aproveitamento de $87,5 \%$ das medições.

Portanto, consideramos que os valores médios apresentados na Tabela 6.15, demonstram a real condição física do Monumento às Bandeiras para a avaliação da propagação de onda ultrassônica pelo método da transmissão direta.

Tabela 6.15 - Resultados médios e desvios finais das avaliações efetuadas no Monumento às Bandeiras.

\begin{tabular}{ccccc}
\hline Transdutores & $\begin{array}{c}\text { Velocidade } \\
\text { Média (m/s) }\end{array}$ & $\begin{array}{c}\text { Desvio Padrão } \\
(\mathbf{m} / \mathbf{s})\end{array}$ & $\begin{array}{c}\text { Afastamento Relativo } \\
(\mathbf{m} / \mathbf{s})\end{array}$ & $\begin{array}{c}\text { Desvio Relativo } \\
\text { Máximo (\%) }\end{array}$ \\
\hline $\mathbf{5 4} \mathbf{~ k H z}$ & 4.749 & 423 & 914 & 19,2 \\
\hline $\mathbf{1 5 0} \mathbf{~ k H z}$ & 4.624 & 436 & 670 & 14,5 \\
\hline
\end{tabular}

\subsubsection{Transmissão Indireta}

As avaliações das velocidades de propagação de ondas ultrassônicas no Monumento às Bandeiras pelo método indireto ocorreram na terceira etapa de medição.

Esta avaliação foi executada em um único local em uma das quatro áreas polidas que constituem inscrições do Monumento às Bandeiras, mais precisamente na placa existente na lateral direita do monumento considerando-se a referência de sua vista frontal.

Da mesma forma que nas figuras do monumento, utilizaram-se os transdutores de 54 $\mathrm{kHz}$ e de $150 \mathrm{kHz}$ para estas avaliações. A definição dos pontos foi feita em uma linha, onde foram determinados 11 pontos para acoplagem dos transdutores emissores e receptores com espaçamento de $10 \mathrm{~cm}$ entre eles.

Foram empregadas duas formas de aplicações das leituras, na primeira forma o transdutor emissor foi mantido fixo no ponto 1 e as leituras foram realizadas aumentando a distância entre os transdutores emissor e receptor, realizando medidas ponto a ponto 
modificando-se o posicionamento do transdutor receptor, iniciando as leituras entre os pontos 1 e 2, passando gradualmente por cada ponto até alcançar a leitura entre os pontos 1 e 11.

A Tabela 6.16 apresenta os valores médios da velocidade de propagação de ondas ultrassônicas aplicados pela transmissão indireta utilizando a forma de avaliação aumentando a distância.

Tabela 6.16 - Resultados médios e desvios referentes à avaliação efetuada pela transmissão indireta em 03/08/2012 pelo aumento gradual de $100 \mathrm{em} 100 \mathrm{~mm}$ entre os transdutores (emissor e receptor).

\begin{tabular}{|c|c|c|c|c|}
\hline Transdutores & $\begin{array}{l}\text { Velocidade } \\
\text { Média }(\mathrm{m} / \mathrm{s})\end{array}$ & $\begin{array}{l}\text { Desvio Padrão } \\
(\mathrm{m} / \mathrm{s})\end{array}$ & $\begin{array}{c}\text { Afastamento Relativo } \\
(\mathrm{m} / \mathrm{s})\end{array}$ & $\begin{array}{l}\text { Desvio Relativo } \\
\text { Máximo (\%) }\end{array}$ \\
\hline $54 \mathrm{kHz}$ & 5.334 & 224 & 456 & 8,5 \\
\hline $150 \mathrm{kHz}$ & 5.210 & 195 & 309 & 5,9 \\
\hline
\end{tabular}

Os resultados obtidos das velocidades médias pela transmissão indireta apresentaram-se muito próximos, e os valores dos desvios obtidos também se mostraram adequados, ocorrência esta que pode ter se dado em função da superfície polida sem imperfeições, o que favoreceu consideravelmente a aplicação do método indireto.

A Figura 6.27 apresenta graficamente o comportamento e distribuição dos resultados para os dois pares de transdutores, mostrando que o comportamento dos valores obtidos nesta avaliação apresenta estabilidade nas leituras, gerando confiabilidade dos resultados. Esperar-se-ia uma diminuição da velocidade conforme aumento da distância, mas isto não se confirmou.

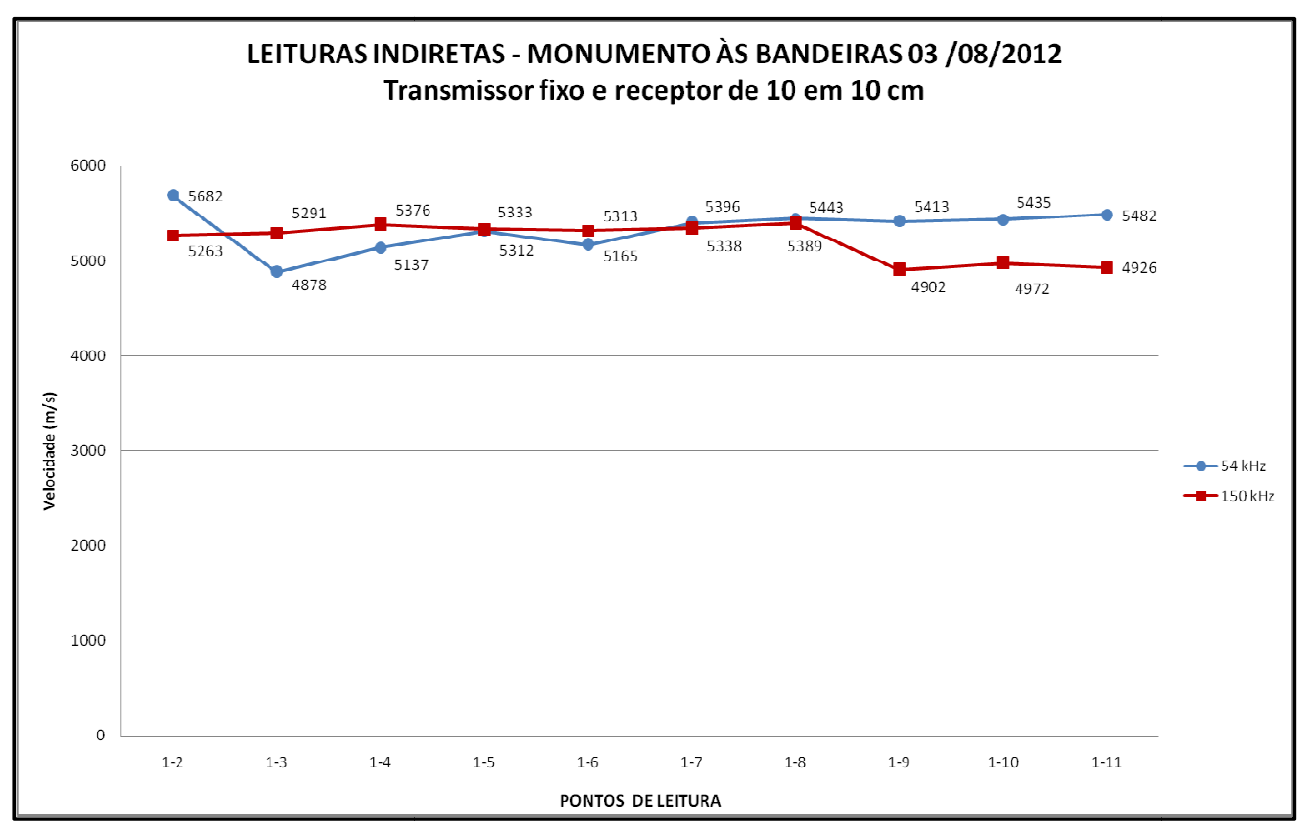

Figura 6.27 - Avaliação efetuada pela transmissão indireta em 03/08/2012 pelo aumento gradual de $100 \mathrm{em}$ $100 \mathrm{~mm}$ entre os transdutores (emissor e receptor). 
A outra avaliação efetuada pela transmissão indireta utilizou dos mesmos pontos para as leituras, no entanto, nesta foram posicionados os transdutores com uma distância fixa de $20 \mathrm{~cm}$ entre eles. Dessa forma, executando leituras dos pontos 1 para 3, 2 para 4, 3 para 5 , e assim sucessivamente até atingir os pontos 8 para 10.

A Tabela 6.17 apresenta os valores médios da velocidade de propagação de ondas ultrassônicas aplicados pela transmissão indireta utilizando-se essa forma de avaliação.

Tabela 6.17 - Resultados Médios e desvios referentes à avaliação efetuada pela transmissão indireta em 03/08/2012 mantendo-se distância fixa de $200 \mathrm{~mm}$ entre os transdutores (emissor e receptor).

\begin{tabular}{ccccc}
\hline Transdutores & $\begin{array}{c}\text { Velocidade } \\
\text { Média (m/s) }\end{array}$ & $\begin{array}{c}\text { Desvio Padrão } \\
(\mathbf{m} / \mathbf{s})\end{array}$ & $\begin{array}{c}\text { Afastamento Relativo } \\
(\mathbf{m} / \mathbf{s})\end{array}$ & $\begin{array}{c}\text { Desvio Relativo } \\
\text { Máximo (\%) }\end{array}$ \\
\hline $\mathbf{5 4} \mathbf{~ k H z}$ & 5.164 & 330 & 599 & 11,6 \\
\hline $\mathbf{1 5 0} \mathbf{~ k H z}$ & 5.199 & 129 & 199 & 3,8 \\
\hline
\end{tabular}

Nesta avaliação o valor médio da velocidade obtida para os transdutores de $54 \mathrm{kHz}$ apresenta-se ligeiramente menor e também o desvio aumenta consideravelmente, já os transdutores de $150 \mathrm{kHz}$ apresentam o valor médio da velocidade na mesma ordem de grandeza da análise anterior, sendo seus desvios inferiores aos obtidos na análise anterior.

A avaliação do gráfico exposto na Figura 6.28 demonstra a maior estabilidade dos resultados obtidos com os transdutores de $150 \mathrm{kHz}$, os transdutores de $54 \mathrm{kHz}$ apresentam resultados também estáveis, no entanto pequenas variações dos valores da velocidade obtidos representam o aumento dos desvios a estes conferidos.

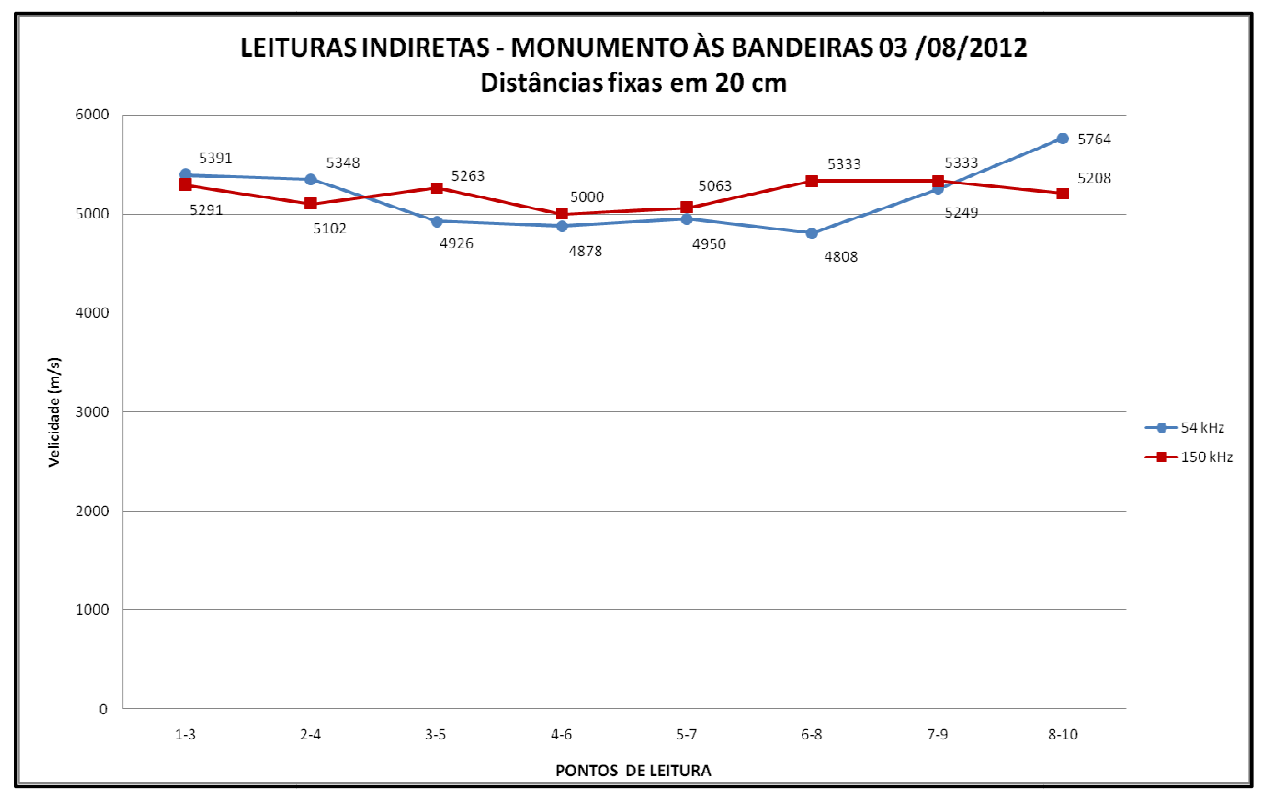

Figura 6.28 - Avaliação efetuada pela transmissão indireta em 03/08/2012 mantendo-se distância fixa de $200 \mathrm{~mm}$ entre os transdutores (emissor e receptor). 


\subsection{Correlação entre as análises de laboratório e Monumento às Bandeiras}

A Tabela 6.18 apresenta os valores médios das velocidades de propagação de ondas ultrassônicas, os resultados mínimos e máximos, obtidos no laboratório e no monumento pelas avaliações das transmissões direta e indireta com os transdutores de 54 $\mathrm{kHz}$ e $150 \mathrm{kHz}$.

Tabela 6.18 - Valores médios da velocidade de propagação de ondas ultrassônicas comparando-se as análises de laboratório com o Monumento às Bandeiras.

\begin{tabular}{|c|c|c|c|c|c|}
\hline \multirow{2}{*}{ Transdutores } & \multirow{2}{*}{ Transmissão } & \multicolumn{2}{|c|}{$\begin{array}{l}\text { Análise de Laboratório } \\
\text { Velocidade Média (m/s) }\end{array}$} & \multicolumn{2}{|c|}{$\begin{array}{l}\text { Monumento às Bandeiras } \\
\text { Velocidade Média }(\mathrm{m} / \mathrm{s})\end{array}$} \\
\hline & & Min. & Máx. & Min. & Máx. \\
\hline \multirow{2}{*}{$54 \mathrm{kHz}$} & Direta & 5.237 & 5.542 & \multicolumn{2}{|c|}{4.749} \\
\hline & Indireta & 4.621 & 5.439 & 5.164 & 5.334 \\
\hline \multirow{2}{*}{$150 \mathrm{kHz}$} & Direta & 5.391 & 5.549 & \multicolumn{2}{|c|}{4.624} \\
\hline & Indireta & 4.820 & 5.233 & 5.199 & 5.210 \\
\hline
\end{tabular}

A Tabela 6.18 demonstra que os resultados obtidos pela transmissão direta no Monumento às Bandeiras apresentam o valor médio da velocidade de propagação de ondas ultrassônicas 9,3\% abaixo do resultado do menor valor médio obtido em laboratório para os transdutores de $54 \mathrm{kHz}$, e de $14,2 \%$ para os transdutores de $150 \mathrm{kHz}$.

O ANEXO II apresenta todas as planilhas com os valores das distâncias e tempos adquiridos durante o estudo nas avaliações no laboratório e no monumento. 


\section{Considerações Finais}

Todas as determinações efetuadas no laboratório, bem como no Monumento às Bandeiras contaram com os mesmos procedimentos, utilizando-se os transdutores de $54 \mathrm{kHz}, 150 \mathrm{kHz}$ e exponenciais.

No entanto, ficou clara a baixa eficiência na obtenção de resultados pela utilização dos transdutores exponenciais, pois os valores obtidos com estes não apresentavam coerência nos valores obtidos das velocidades de propagação de ondas ultrassônicas, bem como na estabilidade dos resultados para um único operador e mesmo utilizando operadores distintos.

Nas avaliações do Monumento às Bandeiras, o comportamento dos transdutores exponenciais também não se mostrou satisfatório, o que nos levou a excluir este par de transdutores dos estudos, assim prosseguido apenas com a utilização dos transdutores de $54 \mathrm{kHz}$ e $150 \mathrm{kHz}$.

Os transdutores de $54 \mathrm{kHz}$ apresentaram resultados coerentes assim como os transdutores de $150 \mathrm{kHz}$, porém por possuírem superfícies de contato maiores que os de $150 \mathrm{kHz}$, o par de $54 \mathrm{kHz}$ é mais suscetível à influência das irregularidades existentes nas bases de leitura, pois dependendo das dimensões das imperfeições ou curvaturas, faz com que a camada de acoplante seja a única maneira de efetuar-se o contato, e o uso de acoplante em uma camada espessa interfere consideravelmente na emissão e recepção de onda.

Dos três pares de transdutores utilizados neste estudo, os transdutores de $150 \mathrm{kHz}$ foram os que demonstraram maior estabilidade nas leituras, tanto nas avaliações efetuadas em laboratório quanto as realizadas pela transmissão direta e indireta no Monumento às Bandeiras.

A correlação dos estudos de laboratório, avaliando-se a amostra coletada, comparada as avaliações in loco efetuadas no Monumento às Bandeiras, apresentaram resultados aproximados, porém os valores médios obtidos no monumento apresentam velocidades inferiores, numa ordem de 9 a 14\%, dependendo do transdutor utilizado.

Para os transdutores de $54 \mathrm{kHz}$, os valores das velocidades obtidos no laboratório para a transmissão direta variam de 5.237 a $5.542 \mathrm{~m} / \mathrm{s}$, sendo o valor médio obtido no monumento de $4.749 \mathrm{~m} / \mathrm{s}$. Este mesmo par de transdutores apresenta na transmissão indireta velocidades apuradas no laboratório variando de 4.621 a $5.439 \mathrm{~m} / \mathrm{s}$ e no monumento os valores obtidos são de 5.164 a $5.334 \mathrm{~m} / \mathrm{s}$.

Já os transdutores de $150 \mathrm{kHz}$, apresentam no laboratório velocidades na transmissão direta variando de 5.391 a $5.549 \mathrm{~m} / \mathrm{s}$, sendo o valor médio obtido por essa 
transmissão no monumento de $4.624 \mathrm{~m} / \mathrm{s}$. Na transmissão indireta os valores obtidos no laboratório são de 4.820 a 5.233 m/s, sendo no monumento na ordem de 5.199 a 5.210 m/s.

Com os resultados obtidos neste estudo, poder-se-ia concluir que nos quase 60 anos de exposição do Monumento às Bandeiras, inaugurado em 25 de Janeiro de 1953, este vem alterando-se com a ação do intemperismo, embora seja ainda muito sutil esta interferência.

De acordo com os valores físicos relacionados à velocidade de propagação de ondas ultrassônicas pela transmissão direta existe a alteração física no monumento.

Já para a transmissão indireta esta diferença é pouco representativa, pois tanto para os transdutores de $54 \mathrm{kHz}$ quanto para os de $150 \mathrm{kHz}$ os resultados máximos e mínimos obtidos no Monumento às Bandeiras encontram-se dentro dos intervalos mínimos e máximos determinados no laboratório, o que caracteriza que não existe ação intempérica sobre o monumento, embora a transmissão indireta pode apresentar valores referentes unicamente à superfície da amostra analisada, o que nos leva a concluir que a placa polida avaliada não apresenta alterações de suas características físicas.

A baixa variação obtida pela transmissão indireta sobre a placa polida do monumento está favorecida pela condição superficial da área estudada, o que não ocorre nas avaliações efetuadas pela transmissão direta no mesmo, pois o posicionamento de transdutores sobre superfícies curvas e irregulares gera erros consideráveis de leituras.

Dessa forma, a conclusão mais correta do estado de conservação do Monumento às Bandeiras é de que não apresenta variações causadas pela ação intempérica, pois a diferença entre os valores médios da velocidade na transmissão direta ocorrem em função da diferença de rugosidade superficial dos locais avaliados.

As avaliações realizadas neste estudo nos permitem perceber que a transmissão direta é a mais aconselhável a ser efetuada, uma vez que a propagação de ondas ultrassônicas tem de transpor o volume do corpo amostrado, considerando todo o percurso da onda através da secção avaliada a cada leitura.

Sempre que possível as avaliações devem ser efetuadas sobre superfícies lisas ou polidas, pois irregularidades superficiais prejudicam o contato dos transdutores com a amostra.

A utilização de dois ou mais pares de transdutores favoreceu a pesquisa, já que a correlação entre os transdutores planos de $54 \mathrm{kHz}$ e $150 \mathrm{kHz}$ forneceu parâmetros comparativos que auxiliaram nas avaliações efetuadas.

Portanto, sugerimos que esta prática seja levada em consideração para estudos futuros, sempre que possível seja efetuado esse tipo de correlação. 
O presente estudo é uma proposta metodológica especifica aplicável a monumentos constituídos em rocha, portanto consideramos que o mesmo pode ser uma referência na adequação de um projeto de norma para tal aplicação. 


\section{Referências Bibliográficas}

ABNT - ASSOCIAÇÃO BRASILEIRA DE NORMAS TÉCNICAS. NBR 8802. 1994. (Rio de Janeiro) Concreto endurecido - Determinação da velocidade de propagação de onda ultra-sônica. 8p.

ABNT - ASSOCIAÇÃO BRASILEIRA DE NORMAS TÉCNICAS. NBR 7215. 1996. (Rio de Janeiro) Cimento Portland - Determinação da resistência à compressão. 8p.

Almesberger, D., Geometrante, R., Rizzo, A. 2000. Ultrasonic Testing Method for the Characterization of Pietra D'Istria Structural Elements. In: $9^{\text {th }}$ International Congress on Deterioration and Conservation of Stone. Veneza. Volume II: 317-325.

Alves, A. 2009. Petrogênese de Plútons Graníticos do Leste Paulista: Geocrolologia, Geoquímica Elemental e Isotópica. Tese de Doutoramento. Instituto de Geociências, Universidade de São Paulo. 194p.

ASTM - AMERICAN SOCIETY FOR TESTING AND MATERIALS. D 2845. 2000. (Philadelphia) Standard method for laboratory determination of pulse velocities and ultrasonic elastic constants of rock. $6 p$.

Augusto, W. C. B. 2009. Caracterização Geológica dos Monumentos da Cidade de São Paulo, SP. Trabalho de Formatura. Instituto de Geociências, Universidade de São Paulo. 41p.

Batista, M. R. 1985. Bandeiras de Brecheret: história de um monumento (1920 - 1953). São Paulo: Departamento do Patrimônio Histórico. 148p.

Calegari, L. 2006. Uso da Onda Ultra-Sônica como meio de controle do processo de secagem da madeira, RS. Dissertação de Mestrado. Centro de Ciências Rurais, Universidade Federal de Santa Maria. 91p.

CPRM - Serviço Geológico do Brasil. 2006. Mapa Geológico do Estado de São Paulo. Programa Geologia do Brasil: Breve Descrição das unidades litoestratigráficas aflorantes no Estado de São Paulo. Escala 1:750.000. 
Del Lama, E. A. 2006. Geologia e Herança Cultural. Revista Brasileira de Geociências, 36(2): 379-381.

Del Lama, E. A., Dehira, L. K., Reys, A. C. dos. 2009. Visão Geológica dos Monumentos da Cidade de São Paulo. Revista Brasileira de Geociências, 39(3): 409-420.

DEPARTAMENTO DO PATRIMÔNIO HISTÓRICO (DPH). Inventário de Obras de Arte em Logradouros Públicos da Cidade de São Paulo: Monumento às Bandeiras. Disponível em: www.prefeitura.sp.gov.br. Acessado em: 13 de outubro de 2012.

Evangelista, A. C. J. 2002. Avaliação da resistência do concreto usando diferentes ensaios não-destrutivos, RJ. Tese de Doutoramento. Engenharia, Universidade Federal do Rio de Janeiro. 219p.

Fitzner, B. 2004.Documentation and evaluation of stone damage on monuments. In: $10^{\text {th }}$ International Congress on Deterioration and Conservation of Stone Estocolmo. 667-690p.

Frascá, M. H. B. O. 2003. Estudos experimentais de alteração acelerada em rochas graníticas para revestimento, SP. Tese de Doutoramento. Instituto de Geociências, Universidade de São Paulo. 264p.

IPT - INSTITUTO DE PESQUISAS TECNOLÓGICAS. 1990. Catálogo das rochas ornamentais do estado de São Paulo. São Paulo. 123p.

JAMES INTRUMENT INC. 2010. V-Meter Mark III ${ }^{\mathrm{TM}}$ Instrument Manual. Chicago. 82p.

Köhler, W., Rohatsch, A., Weber, J. 1996. The Stone Material of the West Portal of St. Stephen's Cathedral in Vienna: Petrological and Ultrasonic Investigation. $I n: 8^{\text {th }}$ International Congress on Deterioration and Conservation of Stone. Berlim, Alemanha. Volume II: 759-767.

Maia, S. M. C. 2004. Estudo integrado geológico/tecnológico de rochas: Os granitos Flores e Jacarandá, RN. Dissertação de Mestrado. Centro de Ciências Exatas e da Terra, Universidade Federal do Rio Grande do Norte. 79p. 
Marques, E. A. G., Barroso, E. V., Menezes Filho, A. P., Vargas Jr., E. do A. 2010. Weathering zones on metamorphic rocks from Rio de Janeiro - Physical, mineralogical and geomechanical characterization. Engineering Geology, 111: $1-18$.

Moreno, M. A. 2003. Metodología de diagnóstico y evaluación de tratamientos para laconservación de los edificios históricos. Introduccíon. Metodología de EstudiosPrévios y Propuesta de Tratamientos. Cuadernos Técnicos. - Instituto Andaluz del Patrimonio histórico. 233p.

Myrin, M., Malaga K. 2008. Evaluation of Consolidation Treatment of Sandstone by Use of Ultrasound Pulse Velocity. In: $11^{\text {th }}$ International Congresso $\mathrm{n}$ Deterioration and Conservation of Stone. Torun, Polônia. Volume I: 441-448.

Navarro, F. C., Artur, A. C., Meyer, A. P. 2003. Velocidade de Ultra-Som como Controle de Qualidade de Granitos Aplicados em Fachadas e Funções Estruturais. IV Simpósio de Rochas Ornamentais do Nordeste. Fortaleza, Ceará. Sessões Técnicas: p.140-152.

Papida, S., Murphy, W., May, E. 2000.The Use of Sound Velocity Determination for the Non-Destructive Estimation of Physical and Microbial Weathering of Limestones and Dolomites. In: $9^{\text {th }}$ International Congress on Deterioration and Conservation of Stone. Veneza. Volume I: 609-617.

Pelizan, T. R. 2004. Estudo de propriedades mecânicas de peças roliças de eucalipto citriodora utilizando a técnica de ultra-som, SP. Dissertação de Mestrado. Escola de Engenharia de São Carlos, Universidade de São Paulo. 70p.

Reys, A. C. dos. 2006. Estado de conservação dos monumentos da cidade de São Paulo. Monografia de Trabalho de Formatura, Instituto de Geociências, Universidade de São Paulo. 131p.

Rossi-Manaresi, R., Tucci, A. 1983. Ultrasonic Test for the Evaluation of the Effectiveness of Sandstone Consolidation. In: $1^{\text {st }}$ International Conference on 
Non-Destructive Testing in Coservation of Works of Art. Associazione Italiana Prove Non Distruttive - Istituto Centrale per il Restauro. Roma. p III/11.1-11.17.

Serway, R. A., Jewett, J.W. Jr. (Eds.). 2004. Princípios de Física: Movimento Ondulatório e Termodinâmica. Vol. 2. 699p.

Silva, L. C. T. da. 2005. Avaliação da Degradação de Rochas em Fachadas de Prédios Históricos: Os Exemplos do Teatro Municipal e do Paço Imperial, Cidade do Rio de Janeiro. Dissertação de Mestrado. Instituto de Geociências. Universidade Federal do Rio de Janeiro. 109p.

Sheremeti-Kabashi, F., Snethlage, R. 2000. Determination of Structural Anisotropy of Carrara Marble with Ultrasonic Measurements. In: $9^{\text {th }}$ International Congress on Deterioration and Conservation of Stone. Veneza. Volume I: 247-253.

Topal, T., Doyuran, V. 1995. Ultrasonic Testing of Artificially Weathered Cappadocian Tuff. In: Preservation and Restoration of Cultural Heritage. Proceeding of the 1995 LCP Congress. Montreux. 205-211p.

Valdeón, L., King M. S., De Freitas M. H. 1992. Ultrasonic Methods for Quantifying the Degradation of Building Stones. In: $7^{\text {th }}$ International Congress on Deterioration and Conservation of Stone. LNEC. Lisboa, Portugal. Volume 2: 697-704p.

Ziegler, G. L. F., Carmo, P. I. O do. 2003. Inspeção e manutenção de estruturas de concreto armado: uso de ensaios não destrutivos. RS. In: XVIII Congresso Regional de Iniciação Científica e Tecnologia. 5p. 
ANEXOS 
PREFEITURA DO MUNICÍPIO DE SÃO PAULO

SECRETARIA MUNICIPAL DE CULTURA

DEPARTAMENTO DO PATRIMÔNIO HISTÓRICO

São Paulo, 28 de março de 2011

Ofício nº 049/ DPH-G/2011

Ref: Desenvolvimento de pesquisa sobre o comportamento de ondas ultrassônicas no Monumento às Bandeiras

Prezado Senhor

Em atenção ao pedido de Vossa Senhoria, para que este Departamento autorizasse a avaliação, através de aparelho não invasivo nem destrutivo, do comportamento das ondas ultrassônicas no Monumento às Bandeiras, vimos pelo presente nos manifestarmos favoravelmente ao pleito, condicionando tal aprovação ao envio, ao final do trabalho de pesquisa, de cópias do relatório técnico, para ser arquivado na Biblioteca da Divisão de Preservação deste Departamento.

Ressaltamos que os resultados a serem alcançados com a ensejada pesquisa em muito contribuirão para os trabalhos de preservação do monumento em pauta.

No ensejo, reiteramos nossos protestos de elevada estima e consideração

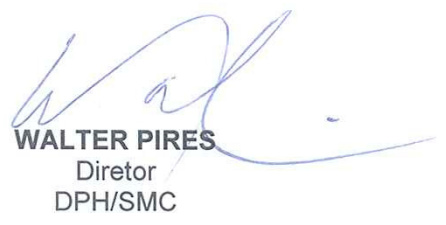

Ilustríssimo Senhor

Alexander Martin Silveira Gimenez

Mestrando pesquisador do Instituto de Geociências da Universidade São Paulo

Avenida José Dini, n 325/ apto 13/ Bloco 02

06763-015 - Taboão da Serra / SP

SAMP

Avenida São João $-473-7^{\circ}$ andar, CEP 01035-000 Fone/fax. 3331-3813 Dphgabinete@prefeitula.sp.gov.br 


\section{ANEXO II}

Tabelas dos valores e resultados obtidos no estudo 
Tabela A.1 - Valores obtidos nas leituras efetuadas na amostra de laboratório pela transmissão direta.

\begin{tabular}{|c|c|c|c|c|c|c|c|c|}
\hline DATA: & \multicolumn{2}{|c|}{$08 / 08 / 2011$} & \multicolumn{6}{|c|}{ Leituras Transmissão Direta - Amostra de Laboratório } \\
\hline \multirow{2}{*}{ Transdutor } & \multirow{2}{*}{ Leitura } & \multirow{2}{*}{ Distância (mm) } & Tempo & Velocidade & Média & Desvio Padrão & Afatamento Relativo & Desvio Relativo Máximo \\
\hline & & & $\left(s^{-3}\right)$ & $(\mathrm{m} / \mathrm{s})$ & $(\mathrm{m} / \mathrm{s})$ & $(\mathrm{m} / \mathrm{s})$ & $(\mathrm{m} / \mathrm{s})$ & (\%) \\
\hline \multirow{4}{*}{$54 \mathrm{kHz}$} & $1 \mathrm{~A} \rightarrow 1 \mathrm{~B}$ & 366,0 & 66,4 & 5512 & \multirow{4}{*}{5542} & \multirow{4}{*}{100,7} & \multirow{4}{*}{143} & \multirow{4}{*}{2,6} \\
\hline & $2 C \rightarrow 2 D$ & 204,1 & 35,9 & 5685 & & & & \\
\hline & $3 C \rightarrow 3 D$ & 195,5 & 35,4 & 5523 & & & & \\
\hline & $4 C \rightarrow 4 D$ & 197,8 & 36,3 & 5449 & & & & \\
\hline \multirow{4}{*}{$150 \mathrm{kHz}$} & $1 \mathrm{~A} \rightarrow 1 \mathrm{~B}$ & 366,0 & 66,3 & 5520 & \multirow{4}{*}{5549} & \multirow{4}{*}{141,6} & \multirow{4}{*}{184} & \multirow{4}{*}{3,3} \\
\hline & $2 C \rightarrow 2 D$ & 204,1 & 35,6 & 5733 & & & & \\
\hline & $3 C \rightarrow 3 D$ & 195,5 & 35,2 & 5554 & & & & \\
\hline & $4 C \rightarrow 4 D$ & 197,8 & 36,7 & 5390 & & & & \\
\hline \multirow{4}{*}{ Exp. } & $1 \mathrm{~A} \rightarrow 1 \mathrm{~B}$ & 366,0 & 177,0 & 2392 & \multirow{4}{*}{3488} & \multirow{4}{*}{755,5} & \multirow{4}{*}{1096} & \multirow{4}{*}{31,4} \\
\hline & $2 C \rightarrow 2 D$ & 204,1 & 74,1 & 4071 & & & & \\
\hline & $3 C \rightarrow 3 D$ & 195,5 & 74,3 & 3884 & & & & \\
\hline & $4 C \rightarrow 4 D$ & 197,8 & 78,8 & 3607 & & & & \\
\hline
\end{tabular}

Tabela A.2 - Valores obtidos nas leituras efetuadas na amostra de laboratório pela transmissão semidireta.

\begin{tabular}{|c|c|c|c|c|c|c|c|c|}
\hline DATA: & \multicolumn{2}{|c|}{$09 / 08 / 2011$} & \multicolumn{6}{|c|}{ Leituras Transmissão Semidireta - Amostra de Laboratório } \\
\hline \multirow{2}{*}{ Transdutor } & \multirow{2}{*}{ Leitura } & \multirow{2}{*}{ Distância (mm) } & Tempo & \begin{tabular}{|l|} 
Velocidade \\
\end{tabular} & Média & Desvio Padrão & Afatamento Relativo & \begin{tabular}{|l|} 
Desvio Relativo Máximo \\
\end{tabular} \\
\hline & & & $\left(s^{-3}\right)$ & $(\mathrm{m} / \mathrm{s})$ & $(\mathrm{m} / \mathrm{s})$ & $(\mathrm{m} / \mathrm{s})$ & $(\mathrm{m} / \mathrm{s})$ & (\%) \\
\hline \multirow{12}{*}{$54 \mathrm{kHz}$} & $1 \mathrm{~A} \rightarrow 2 \mathrm{C}$ & 125,5 & 20,7 & 6063 & \multirow{12}{*}{5748} & \multirow{12}{*}{255,2} & \multirow{12}{*}{444} & \multirow{12}{*}{7,7} \\
\hline & $1 \mathrm{~A} \rightarrow 3 \mathrm{C}$ & 218,6 & 37,9 & 5768 & & & & \\
\hline & $1 \mathrm{~A} \rightarrow 4 \mathrm{C}$ & 337,1 & 60,4 & 5581 & & & & \\
\hline & $1 A \rightarrow 2 D$ & 109,7 & 18,2 & 6027 & & & & \\
\hline & $1 A \rightarrow 3 D$ & 194,1 & 33,6 & 5777 & & & & \\
\hline & $1 A \rightarrow 4 D$ & 306,6 & 56,8 & 5398 & & & & \\
\hline & $1 \mathrm{~B} \rightarrow 2 \mathrm{C}$ & 334,9 & 58,4 & 5735 & & & & \\
\hline & $1 \mathrm{~B} \rightarrow 3 \mathrm{C}$ & 216,5 & 37,4 & 5789 & & & & \\
\hline & $1 B \rightarrow 4 C$ & 122,0 & 22,8 & 5351 & & & & \\
\hline & $1 \mathrm{~B} \rightarrow 2 \mathrm{D}$ & 317,8 & 57,0 & 5575 & & & & \\
\hline & $1 \mathrm{~B} \rightarrow 3 \mathrm{D}$ & 213,9 & 37,4 & 5719 & & & & \\
\hline & $1 \mathrm{~B} \rightarrow 4 \mathrm{D}$ & 112,7 & 18,2 & 6192 & & & & \\
\hline \multirow{12}{*}{$150 \mathrm{kHz}$} & $1 \mathrm{~A} \rightarrow 2 \mathrm{C}$ & 125,5 & 22,9 & 5480 & \multirow{12}{*}{5418} & \multirow{12}{*}{282,0} & \multirow{12}{*}{583} & \multirow{12}{*}{10,8} \\
\hline & $1 \mathrm{~A} \rightarrow 3 \mathrm{C}$ & 218,6 & 39,1 & 5591 & & & & \\
\hline & $1 \mathrm{~A} \rightarrow 4 \mathrm{C}$ & 337,1 & 62,1 & 5428 & & & & \\
\hline & $1 \mathrm{~A} \rightarrow 2 \mathrm{D}$ & 109,7 & 21,9 & 5009 & & & & \\
\hline & $1 A \rightarrow 3 D$ & 194,1 & 37,9 & 5121 & & & & \\
\hline & $1 A \rightarrow 4 D$ & 306,6 & 63,4 & 4836 & & & & \\
\hline & $1 \mathrm{~B} \rightarrow 2 \mathrm{C}$ & 334,9 & 60,5 & 5536 & & & & \\
\hline & $1 \mathrm{~B} \rightarrow 3 \mathrm{C}$ & 216,5 & 38,4 & 5638 & & & & \\
\hline & $1 \mathrm{~B} \rightarrow 4 \mathrm{C}$ & 122,0 & 21,6 & 5648 & & & & \\
\hline & $1 \mathrm{~B} \rightarrow 2 \mathrm{D}$ & 317,8 & 57,1 & 5566 & & & & \\
\hline & $1 \mathrm{~B} \rightarrow 3 \mathrm{D}$ & 213,9 & 39,5 & 5415 & & & & \\
\hline & $1 \mathrm{~B} \rightarrow 4 \mathrm{D}$ & 112,7 & 19,6 & 5750 & & & & \\
\hline \multirow{12}{*}{ EXP. } & $1 A \rightarrow 2 C$ & 125,5 & 71,1 & 2662 & \multirow{12}{*}{3269} & \multirow{12}{*}{589,8} & \multirow{12}{*}{1268} & \multirow{12}{*}{38,8} \\
\hline & $1 A \rightarrow 3 C$ & 218,6 & 103,2 & 2759 & & & & \\
\hline & $1 \mathrm{~A} \rightarrow 4 \mathrm{C}$ & 337,1 & 129,1 & 3206 & & & & \\
\hline & $1 \mathrm{~A} \rightarrow 2 \mathrm{D}$ & 109,7 & 66,0 & 2609 & & & & \\
\hline & $1 A \rightarrow 3 D$ & 194,1 & 80,0 & 3464 & & & & \\
\hline & $1 A \rightarrow 4 D$ & 306,6 & 120,3 & 3182 & & & & \\
\hline & $1 B \rightarrow 2 C$ & 334,9 & 108,4 & 3966 & & & & \\
\hline & $1 \mathrm{~B} \rightarrow 3 \mathrm{C}$ & 216,5 & 85,7 & 3507 & & & & \\
\hline & $1 \mathrm{~B} \rightarrow 4 \mathrm{C}$ & 122,0 & 70,8 & 2605 & & & & \\
\hline & $1 \mathrm{~B} \rightarrow 2 \mathrm{D}$ & 317,8 & 125,3 & 3136 & & & & \\
\hline & $1 \mathrm{~B} \rightarrow 3 \mathrm{D}$ & 213,9 & 83,5 & 3593 & & & & \\
\hline & $1 \mathrm{~B} \rightarrow 4 \mathrm{D}$ & 112,7 & 48,8 & 4537 & & & & \\
\hline
\end{tabular}


Tabela A.3 - Valores obtidos nas leituras efetuadas na amostra de laboratório pela transmissão indireta.

\begin{tabular}{|c|c|c|c|c|c|c|c|c|}
\hline DATA: & \multicolumn{2}{|c|}{$09 / 08 / 2011$} & \multicolumn{6}{|c|}{ Leituras Transmissão Indireta - Amostra de Laboratório } \\
\hline \multirow{2}{*}{ Transdutor } & \multirow{2}{*}{ Leitura } & \multirow{2}{*}{ Distância (mm) } & Tempo & Velocidade & Média & Desvio Padrão & Afatamento Relativo & Desvio Relativo Máximo \\
\hline & & & $\left(s^{-3}\right)$ & $(\mathrm{m} / \mathrm{s})$ & $(\mathrm{m} / \mathrm{s})$ & $(\mathrm{m} / \mathrm{s})$ & $(\mathrm{m} / \mathrm{s})$ & (\%) \\
\hline \multirow{12}{*}{$54 \mathrm{kHz}$} & $2 C \rightarrow 3 C$ & 137,1 & 28,2 & 4862 & \multirow{12}{*}{5439} & \multirow{12}{*}{274,8} & \multirow{12}{*}{577} & \multirow{12}{*}{10,6} \\
\hline & $2 C \rightarrow 4 C$ & 263,1 & 50,2 & 5241 & & & & \\
\hline & $3 C \rightarrow 2 C$ & 137,1 & 24,4 & 5619 & & & & \\
\hline & $3 C \rightarrow 4 C$ & 142,2 & 25,0 & 5688 & & & & \\
\hline & $4 C \rightarrow 2 C$ & 263,1 & 49,0 & 5369 & & & & \\
\hline & $4 C \rightarrow 3 C$ & 142,2 & 24,1 & 5900 & & & & \\
\hline & $2 \mathrm{D} \rightarrow 3 \mathrm{D}$ & 118,9 & 21,0 & 5662 & & & & \\
\hline & $2 D \rightarrow 4 D$ & 237,7 & 45,9 & 5179 & & & & \\
\hline & $3 \mathrm{D} \rightarrow 2 \mathrm{D}$ & 118,9 & 21,3 & 5582 & & & & \\
\hline & $3 \mathrm{D} \rightarrow 4 \mathrm{D}$ & 130,8 & 24,2 & 5405 & & & & \\
\hline & $4 \mathrm{D} \rightarrow 2 \mathrm{D}$ & 237,7 & 44,2 & 5378 & & & & \\
\hline & $4 \mathrm{D} \rightarrow 3 \mathrm{D}$ & 130,8 & 24,3 & 5383 & & & & \\
\hline \multirow{12}{*}{$150 \mathrm{kHz}$} & $2 C \rightarrow 3 C$ & 137,1 & 25,5 & 5376 & \multirow{12}{*}{5233} & \multirow{12}{*}{148,6} & \multirow{12}{*}{295} & \multirow{12}{*}{5,6} \\
\hline & $2 C \rightarrow 4 C$ & 263,1 & 49,8 & 5283 & & & & \\
\hline & $3 C \rightarrow 2 C$ & 137,1 & 26,4 & 5193 & & & & \\
\hline & $3 C \rightarrow 4 C$ & 142,2 & 28,8 & 4938 & & & & \\
\hline & $4 C \rightarrow 2 C$ & 263,1 & 50,8 & 5179 & & & & \\
\hline & $4 C \rightarrow 3 C$ & 142,2 & 27,7 & 5134 & & & & \\
\hline & $2 D \rightarrow 3 D$ & 118,9 & 22,3 & 5332 & & & & \\
\hline & $2 \mathrm{D} \rightarrow 4 \mathrm{D}$ & 237,7 & 47,2 & 5036 & & & & \\
\hline & $3 D \rightarrow 2 D$ & 118,9 & 22,6 & 5261 & & & & \\
\hline & $3 D \rightarrow 4 D$ & 130,8 & 24,5 & 5339 & & & & \\
\hline & $4 \mathrm{D} \rightarrow 2 \mathrm{D}$ & 237,7 & 45,3 & 5247 & & & & \\
\hline & $4 \mathrm{D} \rightarrow 3 \mathrm{D}$ & 130,8 & 23,9 & 5473 & & & & \\
\hline \multirow{12}{*}{ EXP } & $2 C \rightarrow 3 C$ & 137,1 & 67,7 & 3134 & \multirow{12}{*}{2959} & \multirow{12}{*}{279,5} & \multirow{12}{*}{513} & \multirow{12}{*}{17,3} \\
\hline & $2 C \rightarrow 4 C$ & 263,1 & 107,9 & 3134 & & & & \\
\hline & $3 C \rightarrow 2 C$ & 137,1 & 80,0 & 2446 & & & & \\
\hline & $3 C \rightarrow 4 C$ & 142,2 & 67,2 & 3289 & & & & \\
\hline & $4 C \rightarrow 2 C$ & 263,1 & 124,9 & 2606 & & & & \\
\hline & $4 C \rightarrow 3 C$ & 142,2 & 71,1 & 3017 & & & & \\
\hline & $2 D \rightarrow 3 D$ & 118,9 & 62,1 & 3117 & & & & \\
\hline & $2 \mathrm{D} \rightarrow 4 \mathrm{D}$ & 237,7 & 100,4 & 3110 & & & & \\
\hline & $3 \mathrm{D} \rightarrow 2 \mathrm{D}$ & 118,9 & 70,7 & 2544 & & & & \\
\hline & $3 \mathrm{D} \rightarrow 4 \mathrm{D}$ & 130,8 & 64,9 & 3195 & & & & \\
\hline & $4 \mathrm{D} \rightarrow 2 \mathrm{D}$ & 237,7 & 107,3 & 2852 & & & & \\
\hline & $4 D \rightarrow 3 D$ & 130,8 & 66,6 & 3068 & & & & \\
\hline
\end{tabular}


Tabela A.4 - Valores obtidos no comparativo entre operadores pela transmissão direta.

\begin{tabular}{|c|c|c|c|c|c|c|}
\hline \multicolumn{7}{|c|}{ COMPARATIVOS OPERADORES LABORATÓRIO - LEITURAS DIRETAS } \\
\hline \multirow{16}{*}{$54 \mathrm{kHz}$} & \multirow{2}{*}{ Leituras } & \multirow{2}{*}{ Distância } & \multicolumn{4}{|c|}{ Tempo $\left(s^{-3}\right)$} \\
\hline & & & Operador 1 & Operador 2 & Operador 3 & Operador 4 \\
\hline & $1 \mathrm{~A}$ to $1 \mathrm{~B}$ & 366,1 & 66,4 & 69,6 & 70,9 & 70,1 \\
\hline & $2 \mathrm{C}$ to $2 \mathrm{D}$ & 197,5 & 35,9 & 38,2 & 38,5 & 37,7 \\
\hline & $3 C$ to $3 D$ & 195,5 & 35,4 & 36,1 & 36,7 & 36,9 \\
\hline & $4 C$ to $4 \mathrm{D}$ & 204,1 & 36,3 & 37,4 & 38,3 & 38,1 \\
\hline & & \multicolumn{4}{|c|}{$\mathrm{V}(\mathrm{m} / \mathrm{s})$} & \\
\hline & Leituras & Operador 1 & Operador 2 & Operador 3 & Operador 4 & \\
\hline & $1 \mathrm{~A}$ to $1 \mathrm{~B}$ & 5512 & 5260 & 5164 & 5223 & \\
\hline & $2 \mathrm{C}$ to $2 \mathrm{D}$ & 5685 & 5170 & 5130 & 5239 & \\
\hline & $3 C$ to $3 D$ & 5523 & 5416 & 5327 & 5298 & \\
\hline & $4 \mathrm{C}$ to $4 \mathrm{D}$ & 5449 & 5457 & 5329 & 5357 & \\
\hline & Média (m/s) & 5542 & 5326 & 5237 & 5279 & \\
\hline & Desvio Padrão (m/s) & 100,7 & 134,0 & 105,5 & 61,2 & \\
\hline & Afast. Relativo (m/s) & 143 & 156 & 107 & 78 & \\
\hline & Desv. Rel. Máx. (\%) & 2,6 & 2,9 & 2,0 & 1,5 & \\
\hline \multirow{16}{*}{$150 \mathrm{kHz}$} & \multirow{2}{*}{ Leituras } & \multirow{2}{*}{ Distância } & \multicolumn{4}{|c|}{ Tempo $\left(\mathrm{s}^{-3}\right)$} \\
\hline & & & Operador 1 & Operador 2 & Operador 3 & Operador 4 \\
\hline & $1 \mathrm{~A}$ to $1 \mathrm{~B}$ & 366,1 & 66,3 & 66,6 & 68,6 & 68,6 \\
\hline & $2 C$ to $2 D$ & 197,5 & 35,6 & 35,6 & 36,5 & 36,3 \\
\hline & $3 C$ to $3 D$ & 195,5 & 35,2 & 35,6 & 36,2 & 36,4 \\
\hline & $4 C$ to $4 D$ & 204,1 & 36,7 & 36,5 & 37,7 & 37,7 \\
\hline & & \multicolumn{4}{|c|}{$\mathrm{V}(\mathrm{m} / \mathrm{s})$} & \\
\hline & Leituras & Operador 1 & Operador 2 & Operador 3 & Operador 4 & \\
\hline & $1 \mathrm{~A}$ to $1 \mathrm{~B}$ & 5520 & 5497 & 5337 & 5337 & \\
\hline & $2 \mathrm{C}$ to $2 \mathrm{D}$ & 5733 & 5548 & 5411 & 5441 & \\
\hline & $3 C$ to $3 D$ & 5554 & 5492 & 5401 & 5371 & \\
\hline & $4 \mathrm{C}$ to $4 \mathrm{D}$ & 5390 & 5592 & 5414 & 5414 & \\
\hline & Média (m/s) & 5549 & 5532 & 5391 & 5391 & \\
\hline & Desvio Padrão (m/s) & 141,6 & 47,2 & 36,3 & 46,0 & \\
\hline & Afast. Relativo (m/s) & 184 & 60 & 54 & 54 & \\
\hline & Desv. Rel. Máx. (\%) & 3,3 & 1,1 & 1,0 & 1,0 & \\
\hline \multirow{16}{*}{ EXP. } & \multirow{2}{*}{ Leituras } & \multirow{2}{*}{ Distância } & \multicolumn{4}{|c|}{ Tempo $\left(s^{-3}\right)$} \\
\hline & & & Operador 1 & Operador 2 & Operador 3 & Operador 4 \\
\hline & $1 \mathrm{~A}$ to $1 \mathrm{~B}$ & 366,1 & 177,0 & 170,8 & 170,9 & 171,8 \\
\hline & $2 \mathrm{C}$ to $2 \mathrm{D}$ & 197,5 & 78,8 & 76,0 & 76,5 & 77,6 \\
\hline & $3 C$ to $3 D$ & 195,5 & 74,3 & 76,5 & 75,5 & 106,4 \\
\hline & $4 C$ to $4 D$ & 204,1 & 74,1 & 78,6 & 78,7 & 78,5 \\
\hline & & \multicolumn{4}{|c|}{$\mathrm{V}(\mathrm{m} / \mathrm{s})$} & \\
\hline & Leituras & Operador 1 & Operador 2 & Operador 3 & Operador 4 & \\
\hline & $1 \mathrm{~A}$ to $1 \mathrm{~B}$ & 2392 & 2464 & 2462 & 2447 & \\
\hline & $2 \mathrm{C}$ to $2 \mathrm{D}$ & 4071 & 3671 & 3637 & 3565 & \\
\hline & $3 C$ to $3 D$ & 3884 & 3600 & 3668 & 2322 & \\
\hline & $4 C$ to $4 D$ & 3607 & 3619 & 3612 & 3625 & \\
\hline & Média (m/s) & 3488 & 3338 & 3345 & 2990 & \\
\hline & Desvio Padrão (m/s) & 755,5 & 584,0 & 589,0 & 701,2 & \\
\hline & Afast. Relativo (m/s) & 1097,0 & 875,0 & 883,0 & 635,0 & \\
\hline & Desv. Rel. Máx. (\%) & 31,4 & 26,2 & 26,4 & 21,2 & \\
\hline
\end{tabular}


Tabela A.5 - Valores obtidos no comparativo entre operadores pela transmissão semidireta.

\begin{tabular}{|c|c|c|c|c|c|c|c|c|c|c|}
\hline \multicolumn{11}{|c|}{ COMPARATIVOS OPERADORES LABORATORIO - LEITURAS SEMIDIRETAS } \\
\hline \multirow{2}{*}{ Trans. } & \multirow{2}{*}{ Leituras } & \multirow{2}{*}{$\begin{array}{c}\text { Distância } \\
(\mathrm{mm})\end{array}$} & \multicolumn{4}{|c|}{ Tempo $\left(\mathrm{s}^{-3}\right)$} & \multicolumn{4}{|c|}{ Velocidade $(\mathrm{m} / \mathrm{s})$} \\
\hline & & & Operador 1 & Operador 2 & Operador 3 & Operador 4 & Operador 1 & Operador 2 & Operador 3 & Operador 4 \\
\hline \multirow{16}{*}{$54 \mathrm{kHz}$} & $1 \mathrm{~A}$ to $2 \mathrm{C}$ & 125,5 & 20,7 & 23,3 & 21,7 & 20,2 & 6063 & 5386 & 5783 & 6213 \\
\hline & $1 \mathrm{~A}$ to $3 \mathrm{C}$ & 218,6 & 37,9 & 38,7 & 38,8 & 37,4 & 5768 & 5649 & 5634 & 5845 \\
\hline & $1 \mathrm{~A}$ to $4 \mathrm{C}$ & 337,1 & 60,4 & 65,2 & 63,6 & 62,6 & 5581 & 5170 & 5300 & 5385 \\
\hline & $1 \mathrm{~A}$ to $2 \mathrm{D}$ & 109,7 & 18,2 & 18,5 & 18,0 & 17,3 & 6027 & 5930 & 6094 & 6341 \\
\hline & $1 \mathrm{~A}$ to $3 \mathrm{D}$ & 194,1 & 33,6 & 34,4 & 34,4 & 34,4 & 5777 & 5642 & 5642 & 5642 \\
\hline & $1 \mathrm{~A}$ to $4 \mathrm{D}$ & 306,6 & 56,8 & 59,0 & 56,9 & 56,8 & 5398 & 5197 & 5388 & 5398 \\
\hline & $1 \mathrm{~B}$ to $2 \mathrm{C}$ & 334,9 & 58,4 & 60,0 & 60,6 & 60,9 & 5735 & 5582 & 5526 & 5499 \\
\hline & $1 \mathrm{~B}$ to $3 \mathrm{C}$ & 216,5 & 37,4 & 38,1 & 37,4 & 37,7 & 5789 & 5682 & 5789 & 5743 \\
\hline & $1 \mathrm{~B}$ to $4 \mathrm{C}$ & 122,0 & 22,8 & 21,1 & 19,4 & 19,6 & 5351 & 5782 & 6289 & 6224 \\
\hline & $1 \mathrm{~B}$ to $2 \mathrm{D}$ & 317,8 & 57,0 & 57,2 & 59,4 & 58,0 & 5575 & 5556 & 5350 & 5479 \\
\hline & 1Bto 3D & 213,9 & 37,4 & 37,6 & 38,1 & 38,1 & 5719 & 5689 & 5614 & 5614 \\
\hline & $1 \mathrm{~B}$ to $4 \mathrm{D}$ & 112,7 & 18,2 & 18,6 & 19,8 & 20,3 & 6192 & 6059 & 5692 & 5552 \\
\hline & \multicolumn{6}{|c|}{ Velocidade Média (m/s) } & 5748 & 5610 & 5675 & 5745 \\
\hline & \multicolumn{6}{|c|}{ Desvio Padrão (m/s) } & 255,2 & 263,8 & 291,4 & 338,5 \\
\hline & \multicolumn{6}{|c|}{ Afastamento Relativo (m/s) } & 1068 & 449 & 613 & 596 \\
\hline & \multicolumn{6}{|c|}{ Desvio Relativo Máximo (\%) } & 18,6 & 8,0 & 10,8 & 10,4 \\
\hline \multirow{16}{*}{$150 \mathrm{kHz}$} & $1 \mathrm{~A}$ to $2 \mathrm{C}$ & 125,5 & 22,9 & 22,6 & 22,8 & 22,4 & 5480 & 5553 & 5504 & 5603 \\
\hline & $1 \mathrm{~A}$ to $3 \mathrm{C}$ & 218,6 & 39,1 & 38,2 & 40,0 & 39,4 & 5591 & 5723 & 5465 & 5548 \\
\hline & $1 \mathrm{~A}$ to $4 \mathrm{C}$ & 337,1 & 62,1 & 61,8 & 63,7 & 65,1 & 5428 & 5455 & 5292 & 5178 \\
\hline & $1 \mathrm{~A}$ to $2 \mathrm{D}$ & 109,7 & 21,9 & 19,3 & 20,0 & 19,2 & 5009 & 5684 & 5485 & 5714 \\
\hline & $1 \mathrm{~A}$ to $3 \mathrm{D}$ & 194,1 & 37,9 & 34,6 & 37,1 & 35,8 & 5121 & 5610 & 5232 & 5422 \\
\hline & $1 \mathrm{~A}$ to $4 \mathrm{D}$ & 306,6 & 63,4 & 57,0 & 58,7 & 57,5 & 4836 & 5379 & 5223 & 5332 \\
\hline & $1 \mathrm{~B}$ to $2 \mathrm{C}$ & 334,9 & 60,5 & 60,8 & 61,2 & 62,8 & 5536 & 5508 & 5472 & 5333 \\
\hline & $1 \mathrm{~B}$ to $3 \mathrm{C}$ & 216,5 & 38,4 & 39,2 & 40,0 & 39,4 & 5638 & 5523 & 5413 & 5495 \\
\hline & $1 \mathrm{~B}$ to $4 \mathrm{C}$ & 122,0 & 21,6 & 22,0 & 21,8 & 20,9 & 5648 & 5545 & 5596 & 5837 \\
\hline & $1 \mathrm{~B}$ to $2 \mathrm{D}$ & 317,8 & 57,1 & 57,8 & 61,9 & 59,6 & 5566 & 5498 & 5134 & 5332 \\
\hline & 1Bto 3D & 213,9 & 39,5 & 38,8 & 39,0 & 39,3 & 5415 & 5513 & 5485 & 5443 \\
\hline & $1 \mathrm{~B}$ to $4 \mathrm{D}$ & 112,7 & 19,6 & 20,2 & 21,3 & 21,5 & 5750 & 5579 & 5291 & 5242 \\
\hline & \multicolumn{6}{|c|}{ Velocidade Média (m/s) } & 5418 & 5548 & 5383 & 5457 \\
\hline & \multicolumn{6}{|c|}{ Desvio Padrão (m/s) } & 282,0 & 93,9 & 142,6 & 193,9 \\
\hline & \multicolumn{6}{|c|}{ Afastamento Relativo (m/s) } & 582 & 175 & 249 & 381 \\
\hline & \multicolumn{6}{|c|}{ Desvio Relativo Máximo (\%) } & 12,3 & 3,2 & 4,6 & 7,0 \\
\hline \multirow{16}{*}{ EXP. } & $1 \mathrm{~A}$ to $2 \mathrm{C}$ & 125,5 & 71,1 & 86,3 & 73,0 & 71,4 & 2566 & 1958 & 2470 & 2551 \\
\hline & $1 \mathrm{~A}$ to $3 \mathrm{C}$ & 218,6 & 103,2 & 153,4 & 102,9 & 101,6 & 2699 & 1666 & 2709 & 2753 \\
\hline & $1 \mathrm{~A}$ to $4 \mathrm{C}$ & 337,1 & 129,1 & 171,8 & 126,5 & 164,1 & 3153 & 2253 & 3232 & 2376 \\
\hline & $1 \mathrm{~A}$ to $2 \mathrm{D}$ & 109,7 & 66,0 & 62,6 & 63,5 & 67,2 & 2505 & 2715 & 2656 & 2438 \\
\hline & $1 \mathrm{~A}$ to $3 \mathrm{D}$ & 194,1 & 80,0 & 89,8 & 77,3 & 90,3 & 3358 & 2871 & 3523 & 2850 \\
\hline & $1 \mathrm{~A}$ to $4 \mathrm{D}$ & 306,6 & 120,3 & 117,6 & 116,2 & 118,0 & 3125 & 3214 & 3262 & 3200 \\
\hline & $1 \mathrm{~B}$ to $2 \mathrm{C}$ & 334,9 & 108,4 & 174,6 & 147,0 & 145,9 & 3885 & 2198 & 2683 & 2707 \\
\hline & $1 \mathrm{~B}$ to $3 \mathrm{C}$ & 216,5 & 85,7 & 101,6 & 80,3 & 99,9 & 3409 & 2727 & 3726 & 2786 \\
\hline & $1 \mathrm{~B}$ to $4 \mathrm{C}$ & 122,0 & 70,8 & 78,8 & 59,3 & 92,3 & 2510 & 2155 & 3288 & 1740 \\
\hline & $1 \mathrm{~B}$ to $2 \mathrm{D}$ & 317,8 & 125,3 & 144,1 & 134,8 & 146,5 & 3082 & 2607 & 2822 & 2557 \\
\hline & 1Bto 3D & 213,9 & 83,5 & 155,3 & 110,6 & 79,7 & 3489 & 1607 & 2420 & 3720 \\
\hline & $1 \mathrm{~B}$ to $4 \mathrm{D}$ & 112,7 & 48,8 & 68,0 & 47,9 & 67,5 & 4237 & 2461 & 4385 & 2488 \\
\hline & \multicolumn{6}{|c|}{ Velocidade Média (m/s) } & 3168 & 2369 & 3098 & 2681 \\
\hline & & & Desvio P & adrão (m/s) & & & 549,3 & 487,2 & 584,8 & 476,9 \\
\hline & & & Afastamento & Relativo (m & /s) & & 1068 & 845 & 1287 & 1039 \\
\hline & & & esvio Relat & ivo Máximo & (\%) & & 33,7 & 35,7 & 41,5 & 38,8 \\
\hline
\end{tabular}


Tabela A.6 - Valores obtidos no comparativo entre operadores pela transmissão indireta.

\begin{tabular}{|c|c|c|c|c|c|c|c|c|c|c|}
\hline \multicolumn{11}{|c|}{ COMPARATIVOS OPERADORES LABORATORIO - LEITURAS INDIRETAS } \\
\hline \multirow{2}{*}{ Trans. } & \multirow{2}{*}{ Leituras } & \multirow{2}{*}{$\begin{array}{c}\text { Distância } \\
(\mathrm{mm})\end{array}$} & \multicolumn{4}{|c|}{ Tempo $\left(\mathrm{s}^{-3}\right)$} & \multicolumn{4}{|c|}{ Velocidade $(\mathrm{m} / \mathrm{s})$} \\
\hline & & & Operador 1 & Operador 2 & Operador 3 & Operador 4 & Operador 1 & Operador 2 & Operador 3 & Operador 4 \\
\hline \multirow{16}{*}{$54 \mathrm{kHz}$} & $2 \mathrm{C}$ to $3 \mathrm{C}$ & 137,1 & 28,2 & 26,8 & 27,3 & 29,9 & 4862 & 5116 & 5022 & 4585 \\
\hline & $2 \mathrm{C}$ to $4 \mathrm{C}$ & 263,1 & 50,2 & 52,6 & 54,4 & 72,8 & 5241 & 5002 & 4836 & 3614 \\
\hline & $3 \mathrm{C}$ to $2 \mathrm{C}$ & 137,1 & 24,4 & 29,2 & 30,5 & 27,2 & 5619 & 4695 & 4495 & 5040 \\
\hline & $3 \mathrm{C}$ to $4 \mathrm{C}$ & 142,2 & 25,0 & 26,8 & 26,1 & 26,4 & 5688 & 5306 & 5448 & 5386 \\
\hline & $4 \mathrm{C}$ to $2 \mathrm{C}$ & 263,1 & 49,0 & 72,1 & 56,0 & 82,3 & 5369 & 3649 & 4698 & 3197 \\
\hline & $4 \mathrm{C}$ to $3 \mathrm{C}$ & 142,2 & 24,1 & 41,7 & 26,4 & 26,7 & 5900 & 3410 & 5386 & 5326 \\
\hline & $2 \mathrm{D}$ to $3 \mathrm{D}$ & 118,9 & 21,0 & 22,2 & 23,8 & 20,5 & 5662 & 5356 & 4996 & 5800 \\
\hline & $2 \mathrm{D}$ to $4 \mathrm{D}$ & 237,7 & 45,9 & 46,5 & 70,9 & 45,1 & 5179 & 5112 & 3353 & 5271 \\
\hline & $3 \mathrm{D}$ to $2 \mathrm{D}$ & 118,9 & 21,3 & 20,7 & 22,5 & 22,4 & 5582 & 5744 & 5284 & 5308 \\
\hline & $3 \mathrm{D}$ to $4 \mathrm{D}$ & 130,8 & 24,2 & 27,1 & 24,1 & 24,6 & 5405 & 4827 & 5427 & 5317 \\
\hline & $4 \mathrm{D}$ to $2 \mathrm{D}$ & 237,7 & 44,2 & 63,8 & 47,2 & 47,2 & 5378 & 3726 & 5036 & 5036 \\
\hline & $4 \mathrm{D}$ to $3 \mathrm{D}$ & 130,8 & 24,3 & 37,3 & 22,6 & 24,1 & 5383 & 3507 & 5788 & 5427 \\
\hline & \multicolumn{6}{|c|}{ Velocidade Média $(\mathrm{m} / \mathrm{s})$} & 5439 & 4621 & 4981 & 4942 \\
\hline & \multicolumn{6}{|c|}{ Desvio Padrão (m/s) } & 274,8 & 820,4 & 626,5 & 777,8 \\
\hline & \multicolumn{6}{|c|}{ Afastamento Relativo (m/s) } & 577 & 1211 & 1628 & 1745 \\
\hline & \multicolumn{6}{|c|}{ Desvio Relativo Máximo (\%) } & 10,6 & 26,2 & 32,7 & 35,3 \\
\hline \multirow{16}{*}{$150 \mathrm{kHz}$} & $2 \mathrm{C}$ to $3 \mathrm{C}$ & 137,1 & 25,5 & 26,8 & 28,3 & 28,5 & 5376 & 5116 & 4845 & 4811 \\
\hline & $2 \mathrm{C}$ to $4 \mathrm{C}$ & 263,1 & 49,8 & 51,5 & 53,4 & 54,2 & 5283 & 5109 & 4927 & 4854 \\
\hline & $3 \mathrm{C}$ to $2 \mathrm{C}$ & 137,1 & 26,4 & 34,3 & 27,7 & 29,1 & 5193 & 3997 & 4949 & 4711 \\
\hline & $3 \mathrm{C}$ to $4 \mathrm{C}$ & 142,2 & 28,8 & 27,4 & 29,6 & 27,8 & 4938 & 5190 & 4804 & 5115 \\
\hline & $4 \mathrm{C}$ to $2 \mathrm{C}$ & 263,1 & 50,8 & 51,8 & 54,7 & 54,9 & 5179 & 5079 & 4810 & 4792 \\
\hline & $4 \mathrm{C}$ to $3 \mathrm{C}$ & 142,2 & 27,7 & 27,6 & 29,7 & 30,6 & 5134 & 5152 & 4788 & 4647 \\
\hline & $2 D$ to $3 D$ & 118,9 & 22,3 & 23,0 & 25,2 & 24,0 & 5332 & 5170 & 4718 & 4954 \\
\hline & $2 \mathrm{D}$ to $4 \mathrm{D}$ & 237,7 & 47,2 & 46,3 & 47,6 & 45,8 & 5036 & 5134 & 4994 & 5190 \\
\hline & $3 D$ to $2 D$ & 118,9 & 22,6 & 26,6 & 25,6 & 23,6 & 5261 & 4470 & 4645 & 5038 \\
\hline & $3 D$ to $4 D$ & 130,8 & 24,5 & 25,1 & 24,1 & 24,3 & 5339 & 5211 & 5427 & 5383 \\
\hline & $4 \mathrm{D}$ to $2 \mathrm{D}$ & 237,7 & 45,3 & 55,3 & 47,8 & 46,5 & 5247 & 4298 & 4973 & 5112 \\
\hline & $4 \mathrm{D}$ to $3 \mathrm{D}$ & 130,8 & 23,9 & 33,4 & 23,8 & 24,2 & 5473 & 3916 & 5496 & 5398 \\
\hline & \multicolumn{6}{|c|}{ Velocidade Média (m/s) } & 5233 & 4820 & 4948 & 5000 \\
\hline & \multicolumn{6}{|c|}{ Desvio Padrão (m/s) } & 148,6 & 499,8 & 261,8 & 248,4 \\
\hline & \multicolumn{6}{|c|}{ Afastamento Relativo (m/s) } & 295 & 904 & 548 & 398 \\
\hline & \multicolumn{6}{|c|}{ Desvio Relativo Máximo (\%) } & 5,6 & 18,8 & 11,1 & 8,0 \\
\hline \multirow{16}{*}{ EXP. } & $2 \mathrm{C}$ to $3 \mathrm{C}$ & 137,1 & 67,7 & 79,6 & 80,1 & 79,9 & 3134 & 2464 & 2442 & 2451 \\
\hline & $2 \mathrm{C}$ to $4 \mathrm{C}$ & 263,1 & 107,9 & 124,1 & 114,1 & 129,3 & 3134 & 2627 & 2919 & 2498 \\
\hline & $3 \mathrm{C}$ to $2 \mathrm{C}$ & 137,1 & 80,0 & 79,0 & 79,7 & 78,0 & 2446 & 2491 & 2460 & 2537 \\
\hline & $3 \mathrm{C}$ to $4 \mathrm{C}$ & 142,2 & 67,2 & 95,8 & 81,0 & 83,4 & 3289 & 1979 & 2493 & 2392 \\
\hline & $4 \mathrm{C}$ to $2 \mathrm{C}$ & 263,1 & 124,9 & 123,2 & 114,0 & 116,4 & 2606 & 2651 & 2922 & 2846 \\
\hline & $4 C$ to $3 C$ & 142,2 & 71,1 & 81,5 & 81,7 & 81,8 & 3017 & 2471 & 2463 & 2459 \\
\hline & $2 \mathrm{D}$ to $3 \mathrm{D}$ & 118,9 & 62,1 & 70,2 & 74,7 & 73,2 & 3117 & 2571 & 2343 & 2415 \\
\hline & $2 \mathrm{D}$ to $4 \mathrm{D}$ & 237,7 & 100,4 & 124,0 & 114,6 & 115,2 & 3110 & 2376 & 2622 & 2605 \\
\hline & $3 D$ to $2 D$ & 118,9 & 70,7 & 71,3 & 74,3 & 64,3 & 2544 & 2512 & 2362 & 2947 \\
\hline & $3 \mathrm{D}$ to $4 \mathrm{D}$ & 130,8 & 64,9 & 77,0 & 74,5 & 75,2 & 3195 & 2466 & 2588 & 2553 \\
\hline & $4 \mathrm{D}$ to $2 \mathrm{D}$ & 237,7 & 107,3 & 112,6 & 113,4 & 114,4 & 2852 & 2682 & 2658 & 2628 \\
\hline & $4 D$ to $3 D$ & 130,8 & 66,6 & 73,0 & 64,4 & 74,5 & 3068 & 2667 & 3234 & 2588 \\
\hline & \multicolumn{6}{|c|}{ Velocidade Média (m/s) } & 2959 & 2497 & 2626 & 2577 \\
\hline & & & Desvio $P$ & adrão (m/s) & & & 279,5 & 189,5 & 269,9 & 168,4 \\
\hline & & & Afastamento & Relativo (n & $n / s)$ & & 513 & 517 & 609 & 371 \\
\hline & & & Desvio Relat & ivo Máximo & $(\%)$ & & 17,3 & 20,7 & 23,2 & 14,4 \\
\hline
\end{tabular}


Tabela A.7 - Valores obtidos na primeira etapa de avaliação no Monumento às Bandeiras pela transmissão direta.

\begin{tabular}{|c|c|c|c|c|c|c|c|}
\hline \multicolumn{8}{|c|}{ RESULTADOS OBTIDOS NO MONUMENTO ÀS BANDEIRAS EM 12/08/2011 } \\
\hline \multirow{2}{*}{ PONTO } & \multirow{2}{*}{ DISTÂNCIA } & \multicolumn{3}{|c|}{ TEMPO PARA TRANSDUTOR DE: $\left(\mathrm{s}^{-3}\right)$} & \multicolumn{3}{|c|}{ VELOCIDADE PARA TRANSDUTOR DE: $(\mathrm{m} / \mathrm{s})$} \\
\hline & & $54 \mathrm{kHz}$ & $150 \mathrm{kHz}$ & Exponencial & $54 \mathrm{kHz}$ & $150 \mathrm{kHz}$ & Exponencial \\
\hline P1 & 118,1 & 65,6 & 42,1 & 117,4 & 1800 & 2805 & 1241 \\
\hline $\mathrm{P} 2$ & 364,1 & 170,4 & 70,5 & 218,1 & 2137 & 5165 & 1859 \\
\hline P3 & 342,8 & 186,2 & 68,7 & 233,4 & 1841 & 4990 & 1623 \\
\hline P4 & 367,6 & 74,2 & 70,6 & 218 & 4954 & 5207 & 1877 \\
\hline P5 & 293,7 & 59,3 & 57,7 & 143 & 4953 & 5090 & 2431 \\
\hline P6 & 175 & 36,8 & 36,2 & 82 & 4755 & 4834 & 2926 \\
\hline P7 & 179,4 & 36,7 & 36 & 76 & 4888 & 4983 & 3335 \\
\hline P8 & 178,3 & 36,7 & 35,9 & 160,4 & 4858 & 4967 & 1290 \\
\hline P9 & 317,9 & 160,5 & 67,1 & 178 & 1981 & 4738 & 2040 \\
\hline P10 & 251,9 & 51,4 & 56 & 180 & 4901 & 4498 & 1596 \\
\hline \multicolumn{5}{|c|}{ Média (m/s) } & 3707 & 4728 & 2022 \\
\hline \multicolumn{5}{|c|}{ Desvio Padrão (m/s) } & 1446,2 & 671,0 & 651,4 \\
\hline \multicolumn{5}{|c|}{ Afastamento Relativo $(\mathrm{m} / \mathrm{s})$} & 1907 & 1922 & 1313 \\
\hline \multicolumn{5}{|c|}{ Desvio Relativo Máximo (\%) } & 51,4 & 40,7 & 64,9 \\
\hline
\end{tabular}

Tabela A.8 - Valores obtidos na segunda etapa de avaliação no Monumento às Bandeiras pela transmissão direta.

\begin{tabular}{|c|c|c|c|c|c|}
\hline \multicolumn{6}{|c|}{ RESULTADOS OBTIDOS NO MONUMENTO ÀS BANDEIRAS EM 25/05/2012 } \\
\hline \multirow{2}{*}{ PONTO } & \multirow{2}{*}{ DISTÂNCIA } & \multicolumn{2}{|c|}{ TEMPO PARA TRANSDUTOR DE: $\left(\mathrm{s}^{-3}\right)$} & \multicolumn{2}{|c|}{ VELOCIDADE PARA TRANSDUTOR DE: $(\mathrm{m} / \mathrm{s})$} \\
\hline & & $54 \mathrm{kHz}$ & $150 \mathrm{kHz}$ & $54 \mathrm{kHz}$ & $150 \mathrm{kHz}$ \\
\hline P11 & 299 & 58,6 & 59,3 & 5102 & 5042 \\
\hline P12 & 297 & 57,2 & 56,6 & 5192 & 5247 \\
\hline $\mathrm{P} 13$ & 367 & 194,4 & 89,2 & 1888 & 4114 \\
\hline P14 & 325 & 84,1 & 78,9 & 3864 & 4119 \\
\hline P15 & 279 & 58 & 56,4 & 4810 & 4947 \\
\hline P16 & 284 & 56,3 & 70,4 & 5044 & 4034 \\
\hline P17 & 282 & 75,8 & 78,4 & 3720 & 3597 \\
\hline P18 & 381 & 88,2 & 82,2 & 4320 & 4635 \\
\hline P19 & 471 & 105,4 & 107,8 & 4469 & 4369 \\
\hline $\mathrm{P} 20$ & 322 & 65,6 & 70,3 & 4909 & 4580 \\
\hline $\mathrm{P} 21$ & 459 & 115,1 & 115,5 & 3988 & 3974 \\
\hline $\mathrm{P} 22$ & 416 & 107,2 & 94,2 & 3881 & 4416 \\
\hline $\mathrm{P} 23$ & 287 & 60,6 & 68,2 & 4736 & 4208 \\
\hline P24 & 301 & 79,6 & 73,5 & 3781 & 4095 \\
\hline \multicolumn{4}{|c|}{ Média $(\mathrm{m} / \mathrm{s})$} & 4265 & 4384 \\
\hline \multicolumn{4}{|c|}{ Desvio Padrão (m/s) } & 832,9 & 444,4 \\
\hline \multicolumn{4}{|c|}{ Afastamento Relativo (m/s) } & 2377 & 863 \\
\hline \multicolumn{4}{|c|}{ Desvio Relativo Máximo (\%) } & 55,7 & 19,7 \\
\hline
\end{tabular}


Tabela A.9 - Resultados globais obtidos nas duas etapas de avaliações no Monumento às Bandeiras pela transmissão direta.

\begin{tabular}{|c|c|c|c|c|c||}
\hline \multicolumn{5}{|c|}{ AMOSTRAGEM DOS DOIS PRIMEIROS CAMPOS NO MONUMENTO } \\
\hline \multirow{2}{*}{ PONTO } & \multirow{2}{*}{$\begin{array}{c}\text { DIST. } \\
(\mathrm{mm})\end{array}$} & \multicolumn{2}{|c|}{ TEMPO $\left(\mathrm{s}^{-3}\right)$} & \multicolumn{2}{c|}{ VELOCIDADE $(\mathrm{m} / \mathrm{s})$} \\
\cline { 3 - 6 } & $54 \mathrm{kHz}$ & $150 \mathrm{kHz}$ & $54 \mathrm{kHz}$ & $150 \mathrm{kHz}$ \\
\hline P1 & 118 & 65,6 & 42,1 & 1800 & 2805 \\
\hline P2 & 364 & 170,4 & 70,5 & 2137 & 5165 \\
\hline P3 & 343 & 186,2 & 68,7 & 1841 & 4990 \\
\hline P4 & 368 & 74,2 & 70,6 & 4954 & 5207 \\
\hline P5 & 294 & 59,3 & 57,7 & 4953 & 5090 \\
\hline P6 & 175 & 36,8 & 36,2 & 4755 & 4834 \\
\hline P7 & 179 & 36,7 & 36 & 4888 & 4983 \\
\hline P8 & 178 & 36,7 & 35,9 & 4858 & 4967 \\
\hline P9 & 318 & 160,5 & 67,1 & 1981 & 4738 \\
\hline P10 & 252 & 51,4 & 56 & 4901 & 4498 \\
\hline P11 & 299 & 58,6 & 59,3 & 5102 & 5042 \\
\hline P12 & 297 & 57,2 & 56,6 & 5192 & 5247 \\
\hline P13 & 367 & 194,4 & 89,2 & 1888 & 4114 \\
\hline P14 & 325 & 84,1 & 78,9 & 3864 & 4119 \\
\hline P15 & 279 & 58 & 56,4 & 4810 & 4947 \\
\hline P16 & 284 & 56,3 & 70,4 & 5044 & 4034 \\
\hline P17 & 282 & 75,8 & 78,4 & 3720 & 3597 \\
\hline P18 & 381 & 88,2 & 82,2 & 4320 & 4635 \\
\hline P19 & 471 & 105,4 & 107,8 & 4469 & 4369 \\
\hline P20 & 322 & 65,6 & 70,3 & 4909 & 4580 \\
\hline P21 & 459 & 115,1 & 115,5 & 3988 & 3974 \\
\hline P22 & 416 & 107,2 & 94,2 & 3881 & 4416 \\
\hline P23 & 287 & 60,6 & 68,2 & 4736 & 4208 \\
\hline P24 & 301 & 79,6 & 73,5 & 3781 & 4095 \\
\hline & Média (m/s) & & $\mathbf{4 0 3 2}$ & $\mathbf{4 5 2 7}$ \\
\hline & Desvio Padrão (m/s) & & $\mathbf{1 1 8 7 , 7}$ & $\mathbf{5 8 8 , 1}$ \\
\hline & Desvio Relativo Máximo (\%) & & $\mathbf{5 5 , 4}$ & $\mathbf{3 8 , 0}$ \\
\hline
\end{tabular}


Tabela A.10 - Resultados globais obtidos no Monumento às Bandeiras pela transmissão direta após correções efetuadas.

\begin{tabular}{|c|c|c|c|c|c|}
\hline \multicolumn{6}{|c|}{$\begin{array}{l}\text { AMOSTRAGEM DOS DOIS PRIMEIROS CAMPOS NO MONUMENTO } \\
\text { COM CORREÇÕES FEITAS EM 03/08/2012 }\end{array}$} \\
\hline \multirow[b]{2}{*}{ PONTO } & \multirow{2}{*}{$\begin{array}{l}\text { DIST. } \\
(\mathrm{mm})\end{array}$} & \multicolumn{2}{|c|}{$\operatorname{TEMPO}\left(\mathrm{s}^{-3}\right)$} & \multicolumn{2}{|c|}{ VELOCIDADE $(\mathrm{m} / \mathrm{s})$} \\
\hline & & $54 \mathrm{kHz}$ & $150 \mathrm{kHz}$ & $54 \mathrm{kHz}$ & $150 \mathrm{kHz}$ \\
\hline $\mathrm{P} 1 \mathrm{C}$ & 224 & 45,2 & 43,5 & 4956 & 5149 \\
\hline $\mathrm{P} 2 \mathrm{C}$ & 277 & 170,8 & 54,2 & 1622 & 5111 \\
\hline P3 C & 332 & 65,3 & 81,3 & 5081 & 4081 \\
\hline P4 & 368 & 74,2 & 70,6 & 4954 & 5207 \\
\hline P5 & 294 & 59,3 & 57,7 & 4953 & 5090 \\
\hline P6 & 175 & 36,8 & 36,2 & 4755 & 4834 \\
\hline P7 & 179 & 36,7 & 36 & 4888 & 4983 \\
\hline P8 & 178 & 36,7 & 35,9 & 4858 & 4967 \\
\hline P9 C & 311 & 62,6 & 77,2 & 4960 & 4022 \\
\hline P10 & 252 & 51,4 & 56 & 4901 & 4498 \\
\hline P11 & 299 & 58,6 & 59,3 & 5102 & 5042 \\
\hline $\mathrm{P} 12$ & 297 & 57,2 & 56,6 & 5192 & 5247 \\
\hline P13 C & 335,5 & 67,2 & 81,8 & 4993 & 4101 \\
\hline P14 & 325 & 84,1 & 78,9 & 3864 & 4119 \\
\hline P15 & 279 & 58 & 56,4 & 4810 & 4947 \\
\hline $\mathrm{P} 16 \mathrm{C}$ & 251,2 & 47,7 & 56,4 & 5266 & 4454 \\
\hline P17 & 282 & 75,8 & 78,4 & 3720 & 3597 \\
\hline P18 & 381 & 88,2 & 82,2 & 4320 & 4635 \\
\hline $\mathrm{P} 19$ & 471 & 105,4 & 107,8 & 4469 & 4369 \\
\hline $\mathrm{P} 20$ & 322 & 65,6 & 70,3 & 4909 & 4580 \\
\hline $\mathrm{P} 21$ & 459 & 115,1 & 115,5 & 3988 & 3974 \\
\hline $\mathrm{P} 22 \mathrm{C}$ & 404,5 & 141,1 & 88,8 & 2867 & 4555 \\
\hline $\mathrm{P} 23 \mathrm{C}$ & 287,6 & 60,8 & 61,2 & 4730 & 4699 \\
\hline P24 & 301 & 79,6 & 73,5 & 3781 & 4095 \\
\hline \multicolumn{4}{|c|}{ Média (m/s) } & 4498 & 4598 \\
\hline \multicolumn{4}{|c|}{ Desvio Padrão (m/s) } & 845,4 & 469,8 \\
\hline \multicolumn{4}{|c|}{ Afastamento Relativo (m/s) } & 982 & 980 \\
\hline \multicolumn{4}{|c|}{ Desvio Relativo Máximo (\%) } & 21,8 & 21,3 \\
\hline
\end{tabular}

Tabela A.11 - Valores médios globais das avaliações no monumento pela transmissão direta após exclusão por analise gráfica dos pontos P2 C e P22 C.

\begin{tabular}{|c|c|c|}
\hline Média (m/s) & 4702 & 4577 \\
\hline Desvio Padrão (m/s) & 467,2 & 478,2 \\
\hline Afastamento Relativo (m/s) & 982 & 980 \\
\hline Desvio Relativo Máximo (\%) & 20,9 & 21,4 \\
\hline
\end{tabular}


Tabela A.12 - Valores finais das avaliações no monumento pela transmissão direta considerando-se a exclusão dos valores que se apresentaram fora da tolerância de $\mathbf{2 0 \%}$ em relação ao valor médio.

\begin{tabular}{|c|c|c|}
\hline Média (m/s) & 4749 & 4624 \\
\hline Desvio Padrão (m/s) & 422,8 & 435,6 \\
\hline Afastamento Relativo (m/s) & 914 & 670 \\
\hline Desvio Relativo Máximo (\%) & 19,2 & 14,5 \\
\hline
\end{tabular}

Tabela A.13 - Valores obtidos pela transmissão indireta no Monumento às Bandeiras.

\begin{tabular}{|c|c|c|c|c|c|}
\hline \multicolumn{6}{|c|}{ DADOS MONUMENTO LEITURAS INDIRETAS - FACE POLIDA - 03/08/2012 } \\
\hline PONTOS & DISTÂNCIA & \multicolumn{2}{|c|}{ TEMPO $\left(s^{-3}\right)$} & \multicolumn{2}{|c|}{ VELOCIDADE } \\
\hline ORIGEM/DESTINO & $(\mathrm{mm})$ & $54 \mathrm{kHz}$ & $150 \mathrm{kHz}$ & $54 \mathrm{kHz}$ & $150 \mathrm{kHz}$ \\
\hline \multicolumn{6}{|c|}{ TRANSMISSOR FIXO COM ALTERAÇÃO DE DISTÂNCIA 100 A 100 mm } \\
\hline $1-2$ & 100 & 17,6 & 19,0 & 5682 & 5263 \\
\hline $1-3$ & 200 & 41,0 & 37,8 & 4878 & 5291 \\
\hline $1-4$ & 300 & 58,4 & 55,8 & 5137 & 5376 \\
\hline $1-5$ & 400 & 75,3 & 75,0 & 5312 & 5333 \\
\hline $1-6$ & 500 & 96,8 & 94,1 & 5165 & 5313 \\
\hline $1-7$ & 600 & 111,2 & 112,4 & 5396 & 5338 \\
\hline $1-8$ & 700 & 128,6 & 129,9 & 5443 & 5389 \\
\hline $1-9$ & 800 & 147,8 & 163,2 & 5413 & 4902 \\
\hline $1-10$ & 900 & 165,6 & 181,0 & 5435 & 4972 \\
\hline $1-11$ & 1000 & 182,4 & 203,0 & 5482 & 4926 \\
\hline \multirow{2}{*}{\multicolumn{4}{|c|}{$\begin{array}{r}\text { MÉDIA }(\mathrm{m} / \mathrm{s}) \\
\text { DESVIO PADRÃO }(\mathrm{m} / \mathrm{s})\end{array}$}} & 5334 & 5210 \\
\hline & & & & 223,8 & 195,3 \\
\hline \multicolumn{4}{|c|}{ AFASTAMENTO RELATIVO $(\mathrm{m} / \mathrm{s})$} & 456 & 309 \\
\hline \multicolumn{4}{|c|}{ DERVIO RELATIVO MÁXIMO (\%) } & 8,5 & 5,9 \\
\hline \multicolumn{6}{|c|}{ TRANSMISSOR E RECEPTOR PONTO A PONTO COM DISTÂNCIA 200 mm } \\
\hline $1-3$ & 200 & 37,1 & 37,8 & 5391 & 5291 \\
\hline $2-4$ & 200 & 37,4 & 39,2 & 5348 & 5102 \\
\hline $3-5$ & 200 & 40,6 & 38 & 4926 & 5263 \\
\hline $4-6$ & 200 & 41 & 40 & 4878 & 5000 \\
\hline $5-7$ & 200 & 40,4 & 39,5 & 4950 & 5063 \\
\hline $6-8$ & 200 & 41,6 & 37,5 & 4808 & 5333 \\
\hline $7-9$ & 200 & 38,1 & 37,5 & 5249 & 5333 \\
\hline $8-10$ & 200 & 34,7 & 38,4 & 5764 & 5208 \\
\hline $9-11$ & 200 & & 39,5 & & 5063 \\
\hline \multirow{2}{*}{\multicolumn{4}{|c|}{$\begin{array}{r}\text { MÉDIA }(\mathrm{m} / \mathrm{s}) \\
\text { DESVIO PADRÃO }(\mathrm{m} / \mathrm{s})\end{array}$}} & 5164 & 5184 \\
\hline & & & & 330,1 & 128,8 \\
\hline \multicolumn{4}{|c|}{ AFASTAMENTO RELATIVO $(\mathrm{m} / \mathrm{s})$} & 599 & 199 \\
\hline \multicolumn{4}{|c|}{ DERVIO RELATIVO MÁXIMO (\%) } & 11,6 & 3,8 \\
\hline
\end{tabular}

